\title{
It's Not the Left: \\ Ideology and Protest Participation in Old and New Democracies
}

\author{
Filip Kostelka* \& Jan Rovny ${ }^{\dagger}$
}

November 13, 2018

\begin{abstract}
Multiple studies in political science consistently hold that left-wing ideology renders individuals more prone to protest behavior. However, the familiar association between left-wing ideology and protesting is not empirically corroborated in all democratic nations. Building on existing theoretical principles and applying them to diverse political contexts, this paper sheds light on puzzling variation in protest behavior across new and old democracies. It argues that it is not the left that engenders protest. Instead, we demonstrate that which political camp engages in protest behavior depends on its historical legacies and cultural liberalism. Historical legacies reflect the ideological configuration at democratization. Protesting tends to be more common in the ideological camp that opposed the pre-democratic political order. Simultaneously, it is culturally liberal individuals that more likely embrace protest participation, independent of their left-right identification. These theoretical expectations are supported through survey data analyses, explaining contrasting inter- and intra-regional variation in European democracies.
\end{abstract}

\footnotetext{
*University of Essex, UK \& Sciences Po, Paris, France

†Sciences Po, Paris, France
}

\section{Corresponding Author:}

Filip Kostelka, Department of Government, University of Essex, Wivenhoe Park, Colchester, CO4 3SQ, United Kingdom. Email: filip.kostelka@essex.ac.uk. 


\section{Acknowledgment}

We would like to thank Camillo Cristancho, Ruth Dassonneville, Matt Henn, Indridi Indridason, Tatiana Kostadinova, Lukáš Linek, Lenka Rovná, Peter Söderlund, and the members of the Research Chair in Electoral Studies, University of Montreal and the Democracy, Elections and Citizenship Research Group, Universitat Autonoma de Barcelona for useful comments on earlier drafts of this text.

\section{Funding}

This work was supported by a public grant overseen by the French National Research Agency (ANR) as part of the Investissements d'Avenir program LIEPP (ANR-11-LABX0091, ANR-11-IDEX-0005-02).

\section{Author Biographies}

Filip Kostelka is a lecturer (assistant professor) in the Department of Government at the University of Essex and associate researcher at the Centre d'études européennes at Sciences Po, Paris. He in part conducted this study when working as a postdoctoral fellow at the Research Chair in Electoral Studies at the University of Montreal, and in the Institutions and Political Economy Research Group at the University of Barcelona. Filip is particularly interested in political behaviour, party politics, and democratisation. His research has been published in journals such as the American Political Science Review or West European Politics.

Jan Rovny is an assistant professor at the Centre d'études européennes and LIEPP at Sciences Po, Paris. His research concentrates on political competition in Europe, East and West, with the aim of uncovering the political conflict lines in different countries. He explore the issues that political parties contest across the continent, the strategies that different parties follow, as well as the preferences and voting patterns of citizens. Jan is also one of the principal investigators of the Chapel Hill Expert Survey. His work has been published in European Union Politics, European Journal of Political Research, Party Politics, Socio-Economic Review, World Politics and elsewhere. 


\section{Introduction}

Since the late 1960s and 1970s, protesting has gradually become a widely-approved form of political participation in democratic regimes (Mayer and Perrineau, 1992, chapter 4; Norris, 2002; Mayer, 2004; Rucht, 2007; Dalton, 2008; Dalton and Welzel, 2014). However, even though protest activities, such as demonstrations, are overwhelmingly seen as legitimate today, not all political forces take part in them equally. Research on established, mostly Western, democracies has repeatedly found that citizens with left-wing political outlooks are substantially more likely to engage in protest behaviour than right-wingers (Marsh, 1977; Klingemann, 1979; Barnes et al., 1979; Bernhagen \& Marsh, 2007; Meer, Deth, \& Scheepers, 2009; Torcal, Rodon, \& Hierro, 2016). Yet, the reasons for this relationship are disputed in the academic literature. Moreover, studies from more recent democracies in Central and Eastern Europe $(\mathrm{CEE})^{1}$ have reported a reversed relationship and the right's greater propensity to protest (Bernhagen \& Marsh, 2007; Kostelka, 2014). Finally, our own empirical analyses that follow reveal striking cross-country differences within CEE.

This article tackles this puzzling inter- and intra-regional variation. Building on the literature on Western Europe (WE) (Klingemann, 1979; Inglehart, 1979; Mayer \& Perrineau, 1992), we formulate an explicit general theory of the relationship between ideology and protest behaviour. Considering the multi-dimensional nature of political conflict that can be meaningfully expressed as spanning both economic, and non-economic, cultural issues, we argue for two complementary ideology-based explanations of protesting. Our theory is skeptical vis-à-vis the alleged affinity between protesting and core left-wing values such as support for redistributive policies and state intervention in the economy. Instead, we argue that what matters are historical legacies and cultural liberalism. Historical legacies reflect the ideological configuration at democratization. Protesting tends to be more common in the ideological camp that opposed the pre-democratic political order. Cultural liberalism, with its refusal of traditional social hierarchy, is ideologically much more congruent with disruptive political actions. Consequently, it is culturally liberal individuals that are more likely to embrace protest participation, regardless of their left-right affinity.

Our empirical analyses draw on rich data from public opinion surveys, which in total include over 300,000 respondents. They shed light on the contrasting patterns in protest behavior across new and old democracies. They demonstrate that it is not the left that engages in protest behavior, but, in line with our theory, rather those political forces that participated in the struggle for democratization, and those political forces that are more

\footnotetext{
${ }^{1}$ In this article, we interchangeably employ the terms "the East", "CEE" and "post-communist democracies" when referring to democracies that have a communist past and that are located in Central and Eastern Europe. Conversely, when speaking of West European democracies that did not know communism, we refer to "the West", "WE", and "Western democracies".
} 
culturally liberal. While the effects of these factors overlap in the West, they generate over-time and intra-regional variation in Central and Eastern Europe.

In Western Europe, protesting is continuously associated with the left. This is because it was the left which played an important democratizing role both in the early 1900s and in the 1970s. ${ }^{2}$ Furthermore, in the West, it is the left that is also consistently more culturally liberal. At the same time, our analyses demonstrate that it is not left-wing affinity, but rather cultural liberalism that explains the association. Cultural liberalism trumps historical legacies, and those right-wingers who are culturally liberal protest significantly more than culturally conservative left-wingers.

In contrast to Western Europe, in all post-communist democracies, protesting is initially more strongly associated with the political right as a result of the democratization processes that were accompanied by protests against the region's communist dictatorships. Nevertheless, the effect of this initial historical context progressively weakens and, in the second democratic decade, the decisive factor becomes, like in the West, the cultural component of left-right ideology. In those CEE countries where the left is more culturally liberal than the right, left-wingers become more likely to protest than rightwingers, thus emulating established democracies. In other CEE countries, where the left is less culturally liberal than the right, protesting remains more typical of the right.

This article thus contributes to the study of political participation by providing a theoretical explanation, as well as empirical tests that allow us to disentangle the effects of different aspects of left-right ideology on protesting. Furthermore, the cross-national variation we uncover in Central and Eastern Europe strikingly conforms to the ideological patterns reported by studies on party competition in the region. Therefore, besides providing insights on the relationship between ideology and protest participation in general, our findings contribute to a broader picture of the political conflict in post-communist democracies.

We start by reviewing the existing literature on ideology and protest behavior. Critically assessing the proposed explanations of the association between left-wing ideology and protesting in established democracies, we go on to forge a new, not regionally specific general theory. Applying this theory to diverse political contexts in European countries, we formulate testable hypotheses that allow us to assess the diverse mechanisms behind protest behavior more closely. Subsequently, we put our hypotheses to the test using survey data from the European Social Survey and the European Value Survey in a three-step empirical analysis.

\footnotetext{
${ }^{2}$ The latter period corresponds to democratization in Southern European countries (Greece, Portugal, and Spain).
} 


\section{Participation in Protests: Theory \& Hypotheses}

\subsection{Literature review}

Protest is authority-challenging collective action, such as participating in demonstrations, or signing petitions (Klingemann, 1979). Students of political behavior propose a considerable number of different, but largely compatible, perspectives accounting for the variation in individual propensity to protest (see Rucht, 2007 or Mayer, 2010 for an overview). Among the most influential theories, the relative deprivation model (Gurr, 1970) expects that protesting is driven by the level of citizen dissatisfaction, which corresponds to the gap between citizens' expectations and their perception of the state of affairs. Alternatively, the resource model (Dalton, 1988; Verba, Schlozman, and Brady, 1995, see also Tilly, 1975) contends that, like in the case of more conventional political participation, protesters are those who are resourceful in terms of civic skills (mainly but not exclusively developed through education), money, and time. Furthermore, the mobilization model (Rosenstone and Hansen, 1993), echoing the rich literature on social movements (e.g. McCarthy and Zald, 1977), emphasizes the role of political mobilization, which can be both direct (by political organizations and social groups), and indirect (by one's peers). Finally, a prominent approach explaining the variation in protest participation concentrates on ideology and political values. It has extensively documented that, in established democracies, left-wing individuals are substantially more likely to protest than right-wing individuals (Marsh, 1977; Barnes et al., 1979; Mayer \& Perrineau, 1992; Bernhagen \& Marsh, 2007; Meer et al., 2009; Torcal et al., 2016). The literature proposes three reasons for this relationship between left-wing ideology and protest.

The first interpretation sees the relationship as a historical legacy (see Mayer and Perrineau, 1992, p. 139). Since the early beginnings of mass politics in the 19th century, the left has used demonstrations, strikes and other types of protest activities in their fight for political and social rights of the working class. Protest was in fact the main political tool before the extension of electoral suffrage. Even after enfranchisement, protest has remained a part of left-wing parties' "repertoire of collective action" (e.g. Tilly, 1983), quintessentially exemplified in the May Day Parade, organized by the left quasi-continuously since 1890 until today, in most established democracies. From this perspective, the rise of protest participation, triggered by generational change, was naturally more compatible with left-wing political culture, and only more reluctantly accepted on the right side of the political spectrum.

The second interpretation sees the origins of the relationship in the affinity between the ideological objectives of the left, and the disruptive nature of protest participation. The left's greater openness to unconventional participation tools in the 1960s and 1970s seems coherent with its aims to change society. In his pioneering account, Hans-Dieter 
Klingemann (Klingemann, 1979, p. 280) hypothesized that "advocates of change in the direction of greater equality" should be more willing "to incorporate new means of political participation into their action repertory than the defenders of the status quo". He found empirical support for these expectations, and concluded that "leftists, postmaterialists or social equalitarians exhibit a higher tendency to incorporate new modes of political participation in their action repertory than do rightists, materalists, or those people who rank social equality low" (Klingemann, 1979, p. 294). This finding, echoed in more recent works (e.g., Meer et al., 2009), implies that both economically and culturally egalitarian attitudes should drive the association between left-wing ideology and protest participation.

Ronald Inglehart, advancing a similar, but somewhat narrower interpretation, refined Klingeman's initial account. Inglehart argues that it is the rise of post-material values that drives the increase in protest behaviour in established democracies (Inglehart, 1979). According to this interpretation, more post-materialist post-war generations of citizens put greater emphasis on social, intellectual and aesthetic needs than more materialist older generations that prefer economic and physical security (Inglehart, 1977). Post-materialists are more likely to protest since they "have a larger amount of psychic energy available for politics; they are less supportive of the established social order; and subjectively they have less to lose from unconventional political action than do materialists" (Inglehart, 1990, p. 92). Since post-materialist issues are typically embraced by left-wing parties (particularly the new left) and, empirically speaking, post-materialists tend to be left-wing (Inglehart, 1990, pp. 89-91), this explains the relationship between left-wing ideology and protest behaviour. Inglehart's thesis thus "runs counter to the class conflict model's postulate" (Inglehart, 1990, p. 93) and insinuates that what matters for protest participation are not economic, but cultural preferences (see also Hutter and Kriesi, 2013).

In summary, the proposed explanations of the relationship between ideology and protest behavior relate to historical legacies, generally leftist policy goals, or cultural value orientations. They constitute valuable scholarly contributions that are empirically plausible. However, they also suffer from some significant limitations. First, there are reasons to suspect that some of these explanations fit a specific historical context, but may no longer be the driving forces of protest behavior observed in contemporary democratic societies. Second, and more important, these explanations draw exclusively on the historical experience from established, mostly Western, democracies and do not offer clear guidance on what should be expected in other democratic regions with distinct historical legacies and ideological configurations. In the next section, we critically reassess these explanations and formulate an explicit general theory that applies beyond the limits of established democracies. 


\subsection{Theory on Ideology and Protest Participation in Democratic Regimes ${ }^{3}$}

The left-right distinction has been a key heuristic summarizing ideological positions for both the demand and the supply side of politics (Jou \& Dalton, 2017, p. 3). It can be understood as a "superissue" that encapsulates the "major conflicts that are present in the political system" (Inglehart, 1990, p. 273). It can be further broken down to two broad ideological sub-dimensions: economic and cultural (see e.g., Kitschelt 1994). ${ }^{4}$ Consequently, this article works with three conceptually distinct ideological scales. First, the general left-right scale is rooted in the historical understanding of political families, with the left represented by socialist or communist families and later also by the greens, and the right represented by various liberal, Christian, conservative or radical right families. We refer to this super dimension simply as the left-right, and label individuals on it as left- or right-wingers, based on their self-identification on the general left-right scale. The second scale is the economic sub-dimension, which we consider spanning from statist economics on the one hand to free-market economics on the other. Finally, the cultural sub-dimension ranges from cultural conservatism to cultural liberalism. We place individuals on these latter two sub-dimensions based on their economic and cultural preferences.

The way the economic and cultural sub-dimensions associate with the left-right varies across time (Vries, Hakhverdian, \& Lancee, 2013) and space (Marks et al., 2006; Bakker, Jolly, and Polk, 2012; Rovny and Edwards, 2012; Rovny, 2014), but there is one regularity. In practically all democratic regions, general left-wing attitudes have been associated with support for reduction of income inequalities (Dalton, 2006, Table 2; Jou and Dalton, 2017, p. 7). Consequently, should the association between left-wing ideology and protest behaviour apply beyond established Western democracies, the most straightforward mechanism lies in an affinity between protest behavior and support for redistribution and state intervention in the economy.

However, the theoretical rationale for such an affinity in today's democratic world is weak. Indeed, in the late 19th century and the first half of the 20th century, the primary political aim of the left was the economic reorganization of society which would emancipate the working class, a position vehemently contested by the right championing the status quo. This revolutionary principle, together with the left's historically limited

\footnotetext{
${ }^{3}$ This section focuses on the relationship between mainstream ideological orientations and protest participation. In addition, protest participation is likely to be positively associated with ideological extremism (Meer et al., 2009; Torcal et al., 2016), where, however, the driving force may not be the nature of ideological orientations (both the extreme left and extreme right protest) but, rather, the willingness to overthrow the existing political order (i.e. extreme political dissatisfaction). Political ideology may also intervene in the short-term effect on the propensity to protest through the ideological distance between citizens and the political incumbents. We take these factors into account in our empirical analyses below.

${ }^{4}$ The scientific literature shows that these two sub-dimensions may account for positions on additional issues such as European integration (Hooghe, Marks, \& Wilson, 2002; Marks, Hooghe, Nelson, \& Edwards, 2006) or populism (Polk et al., 2017).
} 
ability to pursue its interests through established institutional avenues, induced the left towards greater protest behavior.

Nonetheless, it is unclear whether it was the preference for greater economic equality and redistribution per se that induced the protest behavior of the left. It is more likely that the historical linkage between the left and protesting resulted rather from support for revolutionary political change. The key mechanism triggering protest was possibly not the search for equality, but rather relative deprivation, dissatisfaction, mobilization capacity (through left-wing organizations), and experience with such actions from the preenfranchisement era. In fact, in contrast to the cultural ideological dimension discussed below, there is nothing inherent in the economic dimension that makes citizens natural proponents or opponents of protest behavior. Support for or opposition to redistribution is conceptually unrelated to different forms of political participation. Redistribution supporters may be more favorable to protesting based on their personal situation (e.g. personal resources, trade union membership) but, when these factors (relative deprivation, mobilization) are properly controlled for, differences in protest behavior based on redistribution preferences are theoretically unlikely.

Furthermore, the revolutionary content of left-wing ideology has been significantly blunted since the class compromise of the post-war era (Rueschemeyer, Stephens, Huber, and Stephens, 1992). Today, the principle of economic redistribution lacks revolutionary flavour, and is generally accepted and practiced by both the left and the right, who usually disagree only on the desirable degree of redistribution and state intervention. Consequently, if there was a strong association between economic preferences and protest behavior in the past, it is unlikely that it still holds in contemporary democracies. This implies that left-wingers' greater propensity to protest, observed in the West, is not a default situation in all democratic regimes. Instead, the relationship between ideology and protest behavior is likely to depend on alternative factors: historical legacies and cultural value orientations.

As suggested by scholars studying established democracies, the most salient historical legacy for protest behavior is likely to form in the democratization stage, when democratic regimes are founded and political identities are shaped. Demonstrations, petitions and other types of protests organized by the opposition often accompany democratic transitions (O'Donnell and Schmitter, 1986, p. 58; Huntington, 1991). These events typically legitimize the narrative of a popular uprising against illegitimate, authoritarian rule. They become closely associated with the political identity of the democratic camp, which may be either left- or right-wing. It is the left when the outgoing dictatorship is rightwing (e.g. Southern Europe in the 1970s), and the right when the collapsing dictatorship is left-wing (e.g. CEE after 1989). In general, protest behavior can be expected from those political forces that have historically lacked the ability to proceed via meaningful conventional political channels, consequently mobilizing disruptive actions to voice their 
grievances. However, this historical legacy is presumably strongest in the first democratic years and is likely to decay over time as other factors come to cross-pressure and weaken it.

In contrast to economic preferences, cultural liberalism is conceptually related to protest behavior. ${ }^{5}$ This ideological dimension taps issues such as civil liberties and tolerance of ethnic and sexual minorities. Cultural liberals refuse the idea of "natural" social hierarchies. They focus on freedom and representation of individuals and subgroups that have been marginalized by entrenched social and political conventions and institutions. They value individual rights and emancipation over rigid social rules. Consequently, they represent a logical fit for authority-challenging activities, including protest. On the contrary, cultural conservatives adhere to political and social conventions. They champion traditional societal order and respect for authorities, including the state's repressive apparatus. For them, engaging in activities that are disruptive, that question legitimate institutions and established conventions, and that often result in conflict with the state and its agents, is less ideologically congruent. Cultural conservatives are, therefore, much less likely to protest than cultural liberals. ${ }^{6}$ The affinity between cultural liberalism and protest behavior has implications for the differences in the left's and right's propensity to protest. Depending on how cultural attitudes associate with the left-right continuum, either of the two ideological camps may embrace protest participation.

To recapitulate, there is reason to believe that the relationship between left-right placement and protest behaviour is neither universal, nor direct. The difference between the left and the right in terms of protesting depends on two factors: which of the two camps was the pro-democratic challenger at the time of democratization, and which of the two camps is culturally more liberal. Since the former factor is a legacy, which may be gradually overlaid with new experiences, it is likely to play the greatest role shortly after democratization. In time, it is, at least partially, cross-pressured by the latter, more direct, effect of cultural liberalism.

\subsection{Hypotheses: Regional Variance in Protest Propensity}

In this section, we apply our theory to contemporary European democracies, turning to the particular political contexts in different regions of Europe - East and West - and also within these regions. This focus provides us with variance in terms of the theory's two main driving factors - historical legacies and cultural liberalism - allowing us to generate testable hypotheses about the relationship between ideology and protest behavior.

\footnotetext{
${ }^{5}$ This argument is largely compatible with Ronald Inglehart's thesis discussed above. However, it does not emphasize specific post-material values or characteristics of post-material individuals. Instead, it refers to more general ideological principles of cultural liberalism (e.g. Kitschelt, 1994; Hooghe et al., 2002).

${ }^{6}$ Our theory is clearly probabilistic. This is even more so given that most citizens do not hold perfectly coherent and structured sets of ideological beliefs (Achen and Bartels, 2017, p. 36).
} 
In light of our theory, there are compelling reasons to concur with the existing research and expect that, in Western Europe, it is indeed the left that protests more than the right. In the West, it was primarily the left that organized and represented disenfranchised social strata prior to and during democratization in the late 19th and early 20th century, or that opposed right-wing dictatorships in Southern Europe in the 1970s. At the same time, in all West European democracies, economically statist outlooks and cultural liberalism are generally and uniformly positively correlated (Marks et al., 2006; Bakker et al., 2012). With the rest of the literature, we thus expect a strong and consistent association between left-wing identification and protest across western Europe.

Hypothesis 1 (H1): In West European democracies, protest participation is much stronger among left-wingers than among right-wingers.

The hypothesized association should be driven by cultural liberalism, which exerts more direct effect than the democratization antecedents. Consequently, it should be the case that cultural liberals have greater propensity to protest, independent of their leftright identification. We thus expect that culturally conservative individuals who identify with the left protest less than culturally liberal individuals who identify with the right. ${ }^{7}$ Furthermore, if cultural liberalism is the strongest predictor of protesting, this should not apply only to Western Europe but also to other democratic regions.

In Central and Eastern Europe, the fall of communism, often precipitated by significant citizen involvement and mass demonstrations (Kuran, 1991), led to high levels of protest participation at the beginning of the democratic era. In the following years, however, protest participation, together with political participation in general, declined. This was considered by some a temporary corollary of economic hardships, triggered by post-communist transformation, and labelled as a "post-honeymoon effect" (Inglehart and Catterberg, 2002). ${ }^{8}$ Nonetheless, post-communist citizen engagement in protest activities remains moderate, and significantly lower than in Western democracies (Bernhagen and Marsh, 2007; Kostelka, 2014; Vráblíková, 2014). Besides the transformational difficulties of the region, the low degree of political involvement in CEE has been blamed on communist (or even pre-communist) attitudinal legacies (Jowitt, 1992; Miller, 1992;

\footnotetext{
${ }^{7}$ This is in contrast to most of the literature. One potential exception is Federico, Fisher, and Deason, 2017 who, however, do not study ideology but authoritarianism, which is a personality trait. They find that, in terms of political interest and political participation in general, authoritarianism has a negative effect on left-wingers but not on right-wingers. In contrast, we focus on ideology suggesting that cultural conservatism has a negative effect on both left-wingers' and right-wingers' protest rates.

${ }^{8}$ Regarding the decline, it should be noted that Mason (1995) found that, in terms of demonstrations, participation was limited even during the democratic transitions, except for countries where the regime change took form of a revolution: East Germany, Czechoslovakia and Bulgaria (Romania was not included in his study). This matches recent findings on more conventional forms of participation. For instance, Kostelka $(2015,2017)$ found that the revolutionary democratization context is one of the main causes of the strong post-communist decline in voter turnout.
} 
Sztompka, 1993, 1996, see also Pop-Eleches and Tucker, 2013), weak associational membership (Letki, 2004); strategic divide and pacify policies by post-communist decisionmakers (Vanhuysse, 2006); or corruption and bad governance (Hooghe and Quintelier, 2014).

Although citizens in post-communist democracies are less involved, their protest participation resembles that of their Western counterparts in other respects. For example, protesting is positively correlated with support for democracy and tolerance (Ekiert and Kubik, 1998; Gurin, Petry, and Crte, 2004; Klingemann, Fuchs, and Zielonka, 2006, p. 10), and it is complementary (and not substitutive) to more elite-directed political and electoral participation (Nový, 2014; but see Tătar, 2015). Similarly, like in established democracies (Dalton, 2008), young citizens are more likely to prefer more direct and active "engaged forms of citizenship" to a more passive and conventional "duty-based" forms (Coffé and Lippe, 2010). More generally, Bernhagen and Marsh (2007, p. 65) draw on the Comparative Study of Electoral Systems (CSES) data and conclude that the individual predictors of protest participation (i.e. resources, attitudes and mobilization) are roughly the same both in CEE and in Western Europe (see also Barnes and Simon, 1998). Nevertheless, they find an intriguing difference between the two regions in terms of the effect of ideology:

"It is noteworthy that holding a right-wing worldview has a significant effect on protest participation of roughly equal magnitude in both regions, but in opposite directions: while being right-wing tends to reduce a person's protest activities in the west, it provides a slight boost to the number of activities reported by respondents in the east. Likewise, while left-wing ideology provides the single most important individual-level determinant of protest activity in the west, it is unrelated to protest in the east." (Bernhagen and Marsh, 2007, p. 61)

Bernhagen and Marsh go on to argue that the East-West discrepancy has to do with "differences in meaning and interpretation between the established versus the postcommunist democracies as to what left and right is all about" (Bernhagen and Marsh, 2007 , p. 61). However, they do not develop this line of thought further. A similar finding, but in a bi-variate setting, is also observed by Kostelka (2014), who, in contrast to Bernhagen and Marsh, suggests that the difference between CEE and WE may relate to the socialization impact of regime change in the post-communist region.

The idea that the meaning of the left-right in the CEE differs from Western democracies is widely held. This difference, however, stems not from the meaning of what is economic left, or what is cultural liberalism, but rather from the associations between the two, economic and cultural, outlooks (e.g.: Kitschelt, 1992; Marks et al., 2006; Vachudova and Hooghe, 2009). The economic, as well as the cultural, component of left-right is com- 
parable across the regions. Both Western and Central and Eastern European economic statists support greater government involvement in the economy and greater redistribution (e.g. Pop-Eleches and Tucker, 2010; Rovny, 2015). ${ }^{9}$ Similarly, cultural liberals across Europe advance political and social pluralism, and individual choice. However, while in Western Europe economic statists tend to be consistent proponents of cultural liberalism, that is not the case in the East. Recent research (Rovny and Edwards, 2012; Rovny, 2014, 2015) points to the heterogeneity in the associations between economic and cultural preferences across CEE - a fact that we use to our analytical advantage when testing the divergent effects of economic and cultural preferences on protest participation.

Our first historical legacies argument does not refer to the cultural sub-dimension but to the left-right distinction in general. It emphasizes the divergent historical experience of CEE. While, in WE the pre-democratic political order was defended by the right, in CEE the political status quo was represented by left-wing communist dictatorships. It was thus the predominantly right-wing pro-democratic opposition forces that engaged in protests to put pressure on communist authorities, which ultimately led to regime change. Consequently, protest participation entered the right-wing political repertoire in the early post-communist era. Indeed, "it makes senses that the repertoires that were available to people before 1989 should be available for further use after 1989" (Kopstein, 2003, p. 241). Even if left-wing ideology naturally favors protest participation as suggested by some, the relationship between left-wing ideology and protest participation was thus presumably radically different from that in the West in the first years after democratization. We expect that left-wingers were less likely to protest than right-wingers.

Hypothesis 2 (H2): Unlike in Western democracies, left-leaning individuals in the CEE were less likely to protest than right-leaning individuals in CEE in the early democratic years.

Our second ideological argument underlines the importance of cultural preferences. As mentioned above, the association between economic and cultural views is more heterogeneous in Central and Eastern Europe when compared to Western Europe. While in some CEE countries economic statism is associated with culturally conservative views, in others, economic statists espouse cultural liberalism.

\footnotetext{
${ }^{9}$ In terms of public policies, Tavits and Letki, 2009 found that, despite their fiscally conservative discourse, post-communist right-wing governments effected higher public expenditure than their left-wing counterparts between 1992 and 2004. Nevertheless, Careja and Emmenegger, 2009 analyzed similar data as Tavits and Letki, and came to the opposite conclusion (left-wing governments spent more). Additionally, the significance of partisan differences in terms of fiscal policies is disputed also in established democracies (Blais, Blake, and Dion, 1993; Clark, Golder, and Golder, 2002) or new democracies in Latin America (Fairfield and Garay, 2017). We would contend that some 'right-wing' governments in CEE earn that name not due to their economic programs, but primarily due to their cultural conservatism (see footnote 10 for details on Poland and Hungary).
} 
Past explanations attribute this diverse competition structure to the role of statebuilding and ethnic politics (Rovny, 2014, 2015). The argument rests on two propositions. The first considers the competitive opportunities stemming from post-communist state-building. Three communist federations (Czechoslovakia, the Soviet Union, and Yugoslavia) crumbled in the early 1990s, giving rise to a number of newly independent states. In countries that were peripheral republics of these federations, federal collapse precipitates the formation of local political forces that oppose communism both on economic, and on national grounds. These political forces espouse pro-independence, nationalist and anti-communist positions, thus associating free-market economics with cultural conservatism. On the contrary, in the federal centers, or in unitary states, it is the communist forces that turn to ethno-nationalism as a way to revive their compromised ideology, while the opposition champions economic and cultural liberalism. Here the association between economic and cultural preferences is thus reversed with the free-market forces adopting culturally liberal values.

The second mechanism forming political competition structure in Central and Eastern Europe relates to ethnic politics. In some countries, politically dominant ethnic minorities originate from past federal centres (such as Russia or Serbia). These groups are consequently associated with the political left (for detailed explanation of this association see Rovny, 2014). Here the economically statist left parties espouse the group interests of ethnic minorities, and champion culturally liberal policies that protect minority rights. In other countries, ethnic minorities stem from other backgrounds, and consequently do not have any particular association with the political left. Here the economic statists tend to ignore or scapegoat ethnic minorities, who seek support from economically free-market parties, or from explicitly ethnic parties that, nevertheless, tend to cooperate with the political right.

These two mechanisms overlap to create a particular structure of political competition in each country of the region. Table 1 outlines the various possibilities. Quadrant $\mathrm{A}$ in the table contains countries that were federal peripheries, and that are home to significant domestic minorities from the ex-federal center. Here it is the statist left that espouses cultural liberalism, while the right champions free-market economics combined with national conservatism, reproducing a competition pattern typical for Western Europe. Quadrant B contains countries that were either federal centers, or unitary states. Here economic statists espouse cultural conservatism, while the free-market forces support cultural liberalism. ${ }^{10}$ Finally, quadrant $\mathrm{C}$ contains mixed cases. Both Lithuania

\footnotetext{
${ }^{10} \mathrm{~A}$ word of caution is warranted at this point concerning the political patterning of Hungary and Poland. These countries are highly ethnically homogeneous, and consequently were not affected by domestic ethnic politics (extra-territorial Hungarian ethnics, nonetheless, play an important political role). The structure of competition in these countries was framed by the reformist nature of the Hungarian and Polish communist parties, which negotiated a gradual transition away from communist dictatorship, and transformed themselves into modern, cosmopolitan socialist parties in the early-mid 1990s, during which time they supported economic transition (Grzymala-Busse, 2002). While the competition pattern
} 
and Slovakia were communist federal peripheries, and their break-away from the federal center enabled their left-wing parties to espouse a certain degree of cultural liberalism in the initial state-building period. However, since the dominant ethnic minorities in these countries do not come from the federal center - the dominant ethnic minority in Lithuania are the Poles, while the dominant ethnic minority in Slovakia are the Hungarians - there is no explicit association between these minorities and the political left. Consequently, the left is not naturally driven to champion ethnic minority rights. We thus expect mixed results in the countries of quadrant $\mathrm{C}$.

Table 1: Explaining the Structure of Political Competition in Central \& Eastern Europe

\begin{tabular}{|c|c|c|c|c|}
\hline & \multicolumn{2}{|c|}{$\begin{array}{l}\text { Dominant ethnic minority } \\
\text { from federal center }\end{array}$} & \multicolumn{2}{|c|}{$\begin{array}{l}\text { Other or insignificant } \\
\text { ethnic minorities }\end{array}$} \\
\hline $\begin{array}{l}\text { Federal center } \\
\text { or unitary } \\
\text { state }\end{array}$ & & & $\begin{array}{l}\text { B } \\
\text { Eastern pattern: } \\
\text { Liberal right }\end{array}$ & $\begin{array}{l}\text { Bulgaria } \\
\text { Czech R. } \\
\text { Hungary } \\
\text { Poland } \\
\text { Romania }\end{array}$ \\
\hline $\begin{array}{l}\text { Federal } \\
\text { periphery }\end{array}$ & $\begin{array}{l}\text { A } \\
\text { Western pattern: } \\
\text { Liberal left }\end{array}$ & $\begin{array}{l}\text { Croatia } \\
\text { Estonia } \\
\text { Latvia } \\
\text { Slovenia }\end{array}$ & $\begin{array}{l}\mathbf{C} \\
\text { Mixed pattern }\end{array}$ & $\begin{array}{l}\text { Lithuania } \\
\text { Slovakia }\end{array}$ \\
\hline
\end{tabular}

Note: Adapted from Figure 5 in Rovny, 2014.

This variation in the political patterning in CEE countries provides us with an ideal environment to test the theoretical proposition that protest behaviour is associated with culturally liberal views, independent of economic outlooks. We expect that culturally liberal political forces are more likely to promote, among their supporters, political action beyond electoral participation. The most responsive are presumably those supporters who are themselves culturally liberal and open to protesting. Therefore, the strongest propensity to protest should be observed among liberal left-wingers in quadrant A countries, and liberal right-wingers in quadrant B countries.

Hypothesis 3 (H3): In those CEE countries where left-wing ideology is associated with cultural liberalism (quadrant $A$ in Table 1), left-wing individuals are more likely to protest than right-wingers. In contrast, in those CEE countries where left-wing ideology is culturally conservative (quadrant B in Table 1), left-wing individuals, are less likely to protest than right-wing individuals.

in Hungary and Poland was initially fluid, by the end of the 1990s, the right-wing opposition settled on protectionist, nationalist, and in the case of Poland, Catholic, positions. These culturally conservative forces, however, espouse economic statism, recreating a pattern associating economic statists (represented by these conservative organizations) with cultural conservatism, while pro-market forces (represented primarily by the liberals) are culturally liberal. For details, see section "Political Patterning in Hungary and Poland" in the Electronic Appendix. 


\section{Data and Methods}

Our empirical analysis proceeds in three steps. We first study the relationship between left-right ideology and protest behavior using aggregated data from WE and CEE over time. Subsequently, we turn to country-specific analyses of this relationship within each region. Finally, in the third step, we explore the meaning of left-right attitudes both in WE and in CEE.

To study the evolution of the relationship between ideology and protest behavior over time (Step 1), we use two types of survey data. The European Value Survey (EVS; EVS, 2015) conveniently comprises three time-points that cover the first post-communist decades: the early 1990s (Wave 2, data collected between 1990 and 1993), the turn of the 1990s and 2000s (Wave 3, 1999-2001) and the late 2000s (Wave 4, 2008-2010). The European Social Survey (ESS; ESS, 2016), which started only in the early 2000s (we use the waves of 2002, 2008 and 2012), ${ }^{11}$ has the advantage of covering protest behaviour over a clearly defined period: the last 12 months preceding each wave. ${ }^{12}$ We run logistic regressions in which the dependent variable is reported protest participation. Following earlier studies (e.g. Inglehart and Catterberg, 2002; Jakobsen and Listhaug, 2014; Stockemer, 2014), the variable is dichotomized and coded as one, if respondents report having participated in least one of the two protest behaviours: signing a petition or demonstrating. ${ }^{13}$ As is typical in the scientific literature (e.g. Bernhagen and Marsh, 2007; Pop-Eleches and Tucker, 2010), we operationalize left-wing ideology through a dummy variable based on respondents' self-placement on the left-right scale. ${ }^{14}$ We discuss below and show in the Electronic Appendix that using alternative continuous operationalization of ideology, or setting ideological extremists apart yield the same substantive findings. To test Hypothesis 1, we interact the left-right dummy with EVS/ESS waves to assess whether the regression coefficient changes over-time. In addition, we control for country differences in protest behavior through country dummies. For ease of presentation and

\footnotetext{
${ }^{11}$ Not all countries unfortunately participate in all ESS waves. The three waves we choose allow to compare the largest identical set of East European countries at different points in time.

${ }^{12}$ In the EVS, no time frame is given. Respondents are asked whether they have ever taken part in one of the studied protest activities. Since, in some cases, respondents may not remember their past protest behavior or subconsciously use a specific time frame when answering the question, the EVS protest variable needs to be interpreted with caution.

${ }^{13}$ The combination of the two items in a single measure presupposes that the two items constitute a single latent dimension of protest participation (Quaranta, 2015, chapter 2). To test this assumption empirically, we conducted a Mokken scale analysis (Mokken, 1971). The results fully support our empirical strategy. For each country under study, the scalability coefficient $H$ for a scale combining petitions and demonstrations is superior to 0.3 in both the EVS and ESS datasets. Please, note that our principal results hold when, instead of our preferred dichotomous operationalization, we use an additive scale that varies between 0 and 2 or when we analyze demonstrations and petitions separately. We show these robustness checks in the Electronic Appendix.

${ }^{14}$ The scales range from 1 to 10 (EVS) and 0 to 10 (EES) and left-wing respondents are thus who position themselves on 1 to 5 and 0 to 4 respectively. In the ESS analyses, the left-wing dummy is complemented with a centre dummy (to compare the left to the right), which corresponds to value 5 on the left-right scale.
} 
interpretation, we estimate separate models for the West and for the East. ${ }^{15}$ In this and the following analyses, we apply the survey design weights as recommended in the EVS and ESS codebooks and robust standard errors. ${ }^{16}$

In the next step (Step 2), we explore the variation within the two regions. We first conduct an analysis of the West and the three sub-regions of the East summarized in Table 1: those with the Western, Eastern, and mixed patterns of party competition. Subsequently, we break down the analysis by individual countries. Given its analytically advantageous, clearly defined, time frame (last 12 months) and dense coverage of the recent period (surveys conducted periodically every two years), we employ the ESS (waves 1-7). The dependent and main independent variables are the same as in Step 1. However, in addition to country and ESS wave dummies, we also control for the effects of resources (gender, age, education, interest in politics),${ }^{17}$ dissatisfaction (satisfaction with democracy) ${ }^{18}$ and mobilization (membership of a trade union or "similar organization"). ${ }^{19}$ In addition, we include a variable Ideological opponent of the incumbent that captures whether there is a difference between the respondent's ideology and the colour of the incumbent cabinet. The variable draws on the Parlegov dataset (Döring and Manow, 2016), which uses the 0-10 left-right scale to classify political parties and which we merged with the ESS data. We matched all ESS respondents with their countries' cabinet(s) that governed in the 12 months preceding the ESS interview. The ideological position of each cabinet is the average position of all the constitutive parties on the left-right scale weighted by their seat share in the lower (or only) chamber of national parliament. ${ }^{20}$ The resulting dummy is coded as 1 if the cabinet's position clearly differs from that of the respondent. ${ }^{21}$ We expect that individuals whose ideology is clearly non-congruent with that of the incumbent cabinet are more active protesters (e.g. Meer

\footnotetext{
${ }^{15}$ This way, we always compare the Western left to the Western right and the Eastern left to the Eastern right. Simultaneously, the slopes of all included variables may differ between the East and the West. If, instead, we used a single model, this could be achieved only through a multitude of interactions whose interpretation is much less intuitive for non-linear regression models (e.g. Ai and Norton, 2003; Mood, 2010; Karaca-Mandic, Norton, and Dowd, 2012).

${ }^{16}$ As we include country and survey wave fixed effects and do not expect heterogeneous treatment effects (i.e. we divided the sample into groups of countries based on expected heterogeneity in the treatment effect), clustering of standard errors is not justified (Abadie, Athey, Imbens, and Wooldridge, 2017). This being said, we show in the Electronic Appendix that the use of clustered standard errors yields the same substantive findings.

${ }^{17}$ Variables Age and Education correspond to the number of years of age and years in full time education respectively. We use dummy variables to operationalize gender (Female) and different levels of interest in politics (Very interested, Quite interested, and Hardly interested).

${ }^{18}$ The variable Democratic satisfaction is a scale that varies from 0 (extremely dissatisfied) to 10 (extremely satisfied).

${ }^{19}$ The variable $T U$ member is coded as 1 for trade union members and 0 for non-members.

${ }^{20}$ If two or more cabinets governed during the 12-month period, we use their average ideological position weighted by their respective duration.

${ }^{21}$ We code the dummy as one for left-wingers, right-wingers and centrists when the cabinet's position is higher than 5, lower than 5, or not in the 3.5-6.5 interval respectively. We opt for these cutting points since they allow to identify clear non-congruence between respondents' and cabinets' ideological positions. However, using alternative operationalizations leads to similar results.
} 
et al., 2009; Torcal et al., 2016).

Finally, the exploration of left-right attitudes (Step 3) is executed in two stages. First, we incorporate cultural liberalism in the analysis of protest behaviour to ascertain whether, as hypothesized, it drives the relationship between left-right attitudes and protesting. The measure of cultural liberalism is a continuous scale that combines attitudes on immigration and attitudes towards gays and lesbians, and which varies between 0 (the most culturally conservative) and 1 (the most culturally liberal). ${ }^{22}$ Second, we run an OLS regression to find out how left-right attitudes (the dependent variable) relate to cultural and economic stances (the independent variables). The former corresponds to cultural liberalism and the latter to support for redistribution, which also varies from 0 (no support) to 1 (full support). ${ }^{23}$ All descriptive statistics are available in the Electronic Appendix.

\section{Findings}

\subsection{Ideology and Protest Participation: Aggregated Analysis Over Time}

To assess the relationship between ideology and protest participation we start out by analyzing data spanning more than two-decades of post-1989 politics, demonstrating temporal consistency in Western Europe, and over-time variance in the East. Figure 1 presents the results of the logistic regression of the EVS and ESS data ${ }^{24}$ in terms of the predicted probability to protest. ${ }^{25}$ It reveals two striking differences between the West and the East.

First, as reported in the existing literature, protest participation is substantially stronger in the West than in the East regardless of ideological orientation (or survey used). Second, the impact of ideology on protest participation is also different. In the West, left-wing individuals' probability to engage in protest activities was by approxi-

\footnotetext{
${ }^{22}$ The measure is an additive Likert scale (Cronbach's alpha $=0.6$ ) that combines the standardized versions of the three following variables from ESS: imueclt ("Country's cultural life undermined or enriched by immigrants"), imdfetn ("Allow many/few immigrants of different race/ethnic group from majority"), and freehms ("Gays and lesbians free to live life as they wish"). We rescaled the index to make it vary between 0 and 1.

${ }^{23}$ Support for redistribution is measured via responses to the statement "The government should take measures to reduce differences in income levels." We recoded the variable so that it varies from 0 (strong disagreement) to 1 (strong agreement).

${ }^{24}$ Full results are available in the Electronic Appendix (EA) in Tables EA1 \& EA2.

${ }^{25}$ The predicted probabilities are calculated using the average marginal effects (AME), which indicate average changes in the probability of the outcome that result from a one-unit change in the independent variable and that are estimated across all observations. In the calculation of an average marginal effect, the observations keep their original values on all other independent variables (Bartus, 2005). Contrary to logit coefficients, AME are intuitive and, more importantly, they can be compared across models and samples (Mood, 2010).
} 
Figure 1: Evolution of the Effect of Ideology on Protesting 1990-2012 (EVS \& ESS)
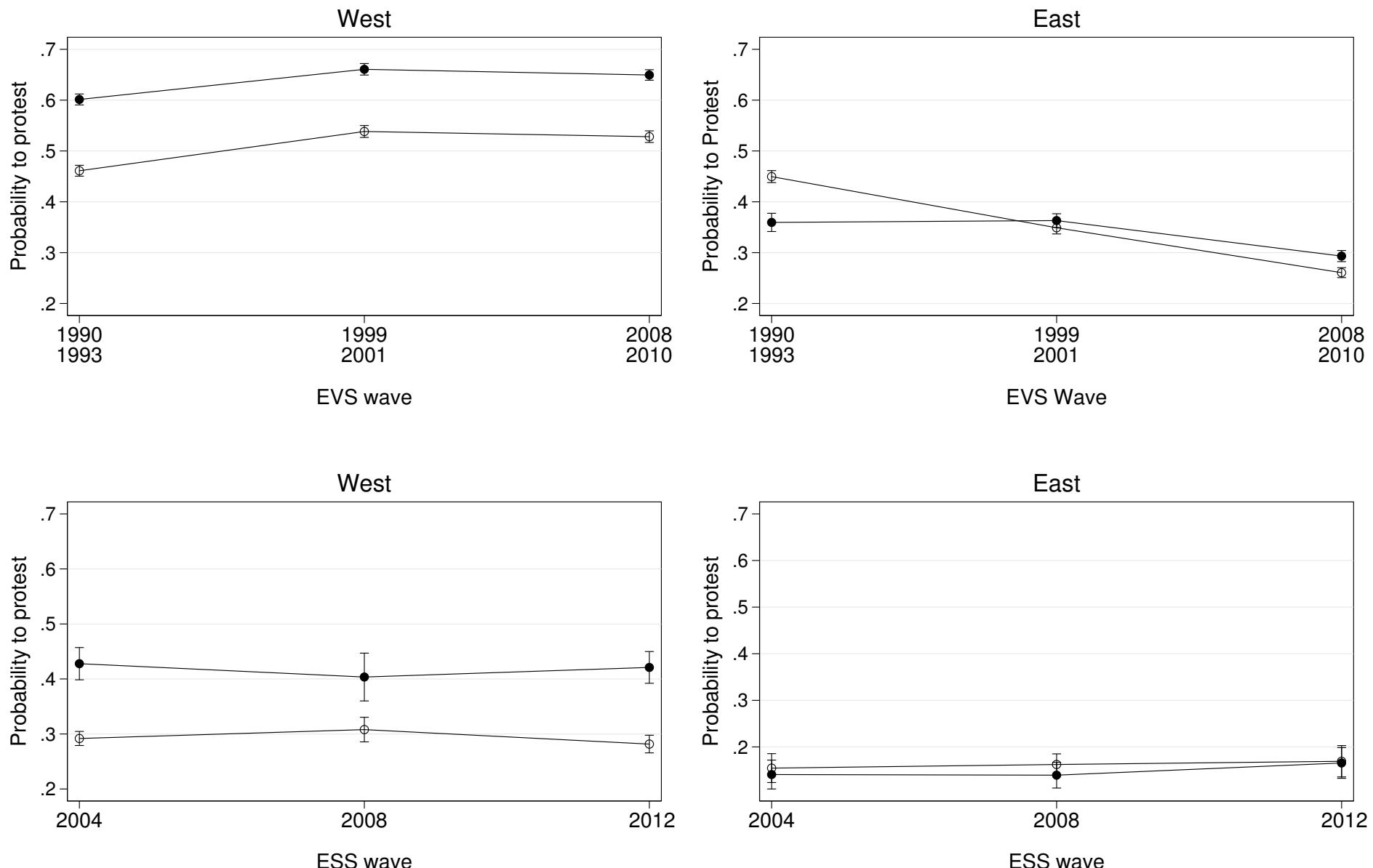

Right-wing

$\longrightarrow$ Left-wing

Note: $95 \%$ confidence intervals. Based on Tables EA1 \& EA2. 
mately 12 percentage points higher than that of right-wing individuals in both datasets. This left-right gap in protesting remained strong and remarkably stable throughout the period at hand, as predicted by Hypothesis 1. In contrast, in the East, the relationship between ideology and protesting evolved over time. In the early 1990s, it was exactly the opposite of the Western pattern. In line with the historical legacy account (Hypothesis 2), left-wing individuals were roughly 9 percentage points less likely to protest than right-wing individuals. Nevertheless, later on, the gap disappeared. In all the post-early 1990s surveys, the difference in the propensity to demonstrate between the left and the right in post-communist countries was substantively negligible, and statistically generally insignificant.

The non-emergence of a clear Western-type association between ideology and protesting invalidates the conventional expectation that left-wing ideology naturally connects to protest behavior. It raises a question whether ideology has no discernible ${ }^{26}$ impact on protest participation in the East, or whether, as Hypothesis 3 suggests, the aggregated analysis conceals heterogeneous patterns of the relationship that co-exist in the region (and cancel out in the aggregate). We explore this in the next sub-section.

\subsection{Ideology and Protest Participation: Intra-Regional Variation}

We now turn to address the relationship between ideology and protest participation within each region, demonstrating its homogeneity across the West, and heterogeneity across the East. At this stage of the analysis, to control for potential cross-pressures that would conceal the effect of ideology, we include all the control variables relative to resources, mobilization, dissatisfaction, and the political color of the incumbent in addition to the ESS wave and country dummies. We first analyze the four groups of countries suggested by Hypothesis 3 (the West and the three sub-regions in the East) and, subsequently, each country separately.

Table 2 and Figure 2 present the results of the aggregated analyses and strongly support Hypothesis 3. They show that, in the West, even when the control variables are included, left-wingers are still much more likely to protest than right-wingers. But, in the East, there is variation in the effect. Left-wingers participate more in protests than right-wingers in CEE countries with the Western pattern of party competition (CEE-WP countries), they participate less in Eastern pattern countries (CEE-EP countries), and there is no statistically significant difference in mixed cases (CEE-MP countries). As an aside, the direction of all the other associations is similar in the West and East although,

\footnotetext{
${ }^{26}$ The absence of an observable relationship does not necessarily mean that ideology does not matter. The effect of ideology may simply be cross-pressured by some of the other factors that also affect participation and that we include in the following analyses.
} 
Table 2: Ideology and Protest Participation (ESS 1-7)

\begin{tabular}{|c|c|c|c|c|}
\hline & $\begin{array}{c}(1) \\
\text { West } \\
\mathrm{b}\end{array}$ & $\begin{array}{c}(2) \\
\text { East: WP } \\
\text { b }\end{array}$ & $\begin{array}{c}(3) \\
\text { East: EP } \\
\text { b }\end{array}$ & $\begin{array}{c}(4) \\
\text { East: MP } \\
\text { b }\end{array}$ \\
\hline Left-wing & $\begin{array}{c}0.45^{* * *} \\
(0.01)\end{array}$ & $\begin{array}{c}0.15^{*} \\
(0.07)\end{array}$ & $\begin{array}{c}-0.27^{* * *} \\
(0.05)\end{array}$ & $\begin{array}{c}-0.03 \\
(0.08)\end{array}$ \\
\hline Center & $\begin{array}{c}0.09^{* * *} \\
(0.02)\end{array}$ & $\begin{array}{l}-0.15^{*} \\
(0.06)\end{array}$ & $\begin{array}{c}-0.42^{* * *} \\
(0.05)\end{array}$ & $\begin{array}{l}-0.09 \\
(0.08)\end{array}$ \\
\hline Female & $\begin{array}{c}0.25^{* * *} \\
(0.01)\end{array}$ & $\begin{array}{c}0.21^{* * *} \\
(0.05)\end{array}$ & $\begin{array}{c}0.06 \\
(0.04)\end{array}$ & $\begin{array}{l}0.10^{+} \\
(0.06)\end{array}$ \\
\hline Age & $\begin{array}{c}-0.01^{* * *} \\
(0.00)\end{array}$ & $\begin{array}{c}-0.02^{* * *} \\
(0.00)\end{array}$ & $\begin{array}{c}-0.02^{* * *} \\
(0.00)\end{array}$ & $\begin{array}{c}-0.02^{* * *} \\
(0.00)\end{array}$ \\
\hline Education (in years) & $\begin{array}{c}0.07^{* * *} \\
(0.00)\end{array}$ & $\begin{array}{c}0.11^{* * *} \\
(0.01)\end{array}$ & $\begin{array}{c}0.13^{* * *} \\
(0.01)\end{array}$ & $\begin{array}{c}0.08^{* * *} \\
(0.01)\end{array}$ \\
\hline Very interested in politics & $\begin{array}{l}1.36^{* * *} \\
(0.03)\end{array}$ & $\begin{array}{l}1.46^{* * *} \\
(0.12)\end{array}$ & $\begin{array}{l}1.78^{* * *} \\
(0.09)\end{array}$ & $\begin{array}{l}1.15^{* * *} \\
(0.16)\end{array}$ \\
\hline Quite interested in politics & $\begin{array}{c}0.98^{* * *} \\
(0.02)\end{array}$ & $\begin{array}{c}1.15^{* * *} \\
(0.10)\end{array}$ & $\begin{array}{l}1.19^{* * *} \\
(0.07)\end{array}$ & $\begin{array}{c}0.89^{* * *} \\
(0.12)\end{array}$ \\
\hline Hardly interested in politics & $\begin{array}{c}0.51^{* * *} \\
(0.02)\end{array}$ & $\begin{array}{c}0.58^{* * *} \\
(0.10)\end{array}$ & $\begin{array}{c}0.61^{* * *} \\
(0.07)\end{array}$ & $\begin{array}{l}0.39^{* *} \\
(0.12)\end{array}$ \\
\hline TU member & $\begin{array}{c}0.32^{* * * *} \\
(0.01)\end{array}$ & $\begin{array}{c}0.36^{* * *} \\
(0.07)\end{array}$ & $\begin{array}{c}0.52^{* * *} \\
(0.06)\end{array}$ & $\begin{array}{c}0.43^{* * *} \\
(0.10)\end{array}$ \\
\hline Democratic satisfaction & $\begin{array}{c}-0.03^{* * *} \\
(0.00)\end{array}$ & $\begin{array}{c}0.00 \\
(0.01)\end{array}$ & $\begin{array}{c}-0.04^{* * *} \\
(0.01)\end{array}$ & $\begin{array}{c}-0.04^{* *} \\
(0.01)\end{array}$ \\
\hline Ideol. opponent of the incumbent & $\begin{array}{c}0.10^{* * *} \\
(0.01)\end{array}$ & $\begin{array}{c}0.04 \\
(0.07)\end{array}$ & $\begin{array}{l}0.08^{+} \\
(0.05)\end{array}$ & $\begin{array}{c}0.02 \\
(0.08)\end{array}$ \\
\hline Constant & $\begin{array}{c}-2.21^{* * *} \\
(0.05)\end{array}$ & $\begin{array}{c}-3.46^{* * *} \\
(0.20)\end{array}$ & $\begin{array}{c}-3.83^{* * *} \\
(0.15)\end{array}$ & $\begin{array}{c}-2.32^{* * *} \\
(0.25)\end{array}$ \\
\hline ESS wave dummies & Yes & Yes & Yes & Yes \\
\hline Country dummies & Yes & Yes & Yes & Yes \\
\hline Observations & 163830 & 16279 & 33781 & 10714 \\
\hline Pseudo $R^{2}$ & 0.10 & 0.11 & 0.10 & 0.06 \\
\hline
\end{tabular}

Note: Logistic regressions. Robust standard errors in parentheses. Significance levels: ${ }^{+} p<0.1,{ }^{*} p<0.05,{ }^{* *} p<0.01,{ }^{* * *} p<0.001$.

in the latter region, some of them lack statistical significance. For instance, those citizens who are younger, more educated, more interested in politics, dissatisfied with the way democracy works in their country, or ideologically opposed to the incumbent cabinet tend to protest more.

We replicated the present analysis for each country in turn and present the results in Figure $3 .^{27}$ In the West, without a single exception, left-wingers always have a stronger propensity to protest than right-wingers. The same is true of CEE-WP countries (Estonia, Croatia, and Slovenia). However, in the two CEE-MP cases (Lithuania and Slovakia), there is not a uniform relationship and, in the CEE-EP countries (Bulgaria, Czech Re-

\footnotetext{
${ }^{27}$ Given the large number of estimates, we opt for a scatter plot design instead of the bar plot in Figure 2 .
} 
Figure 2: Ideology and Protest Participation by Sub-Region

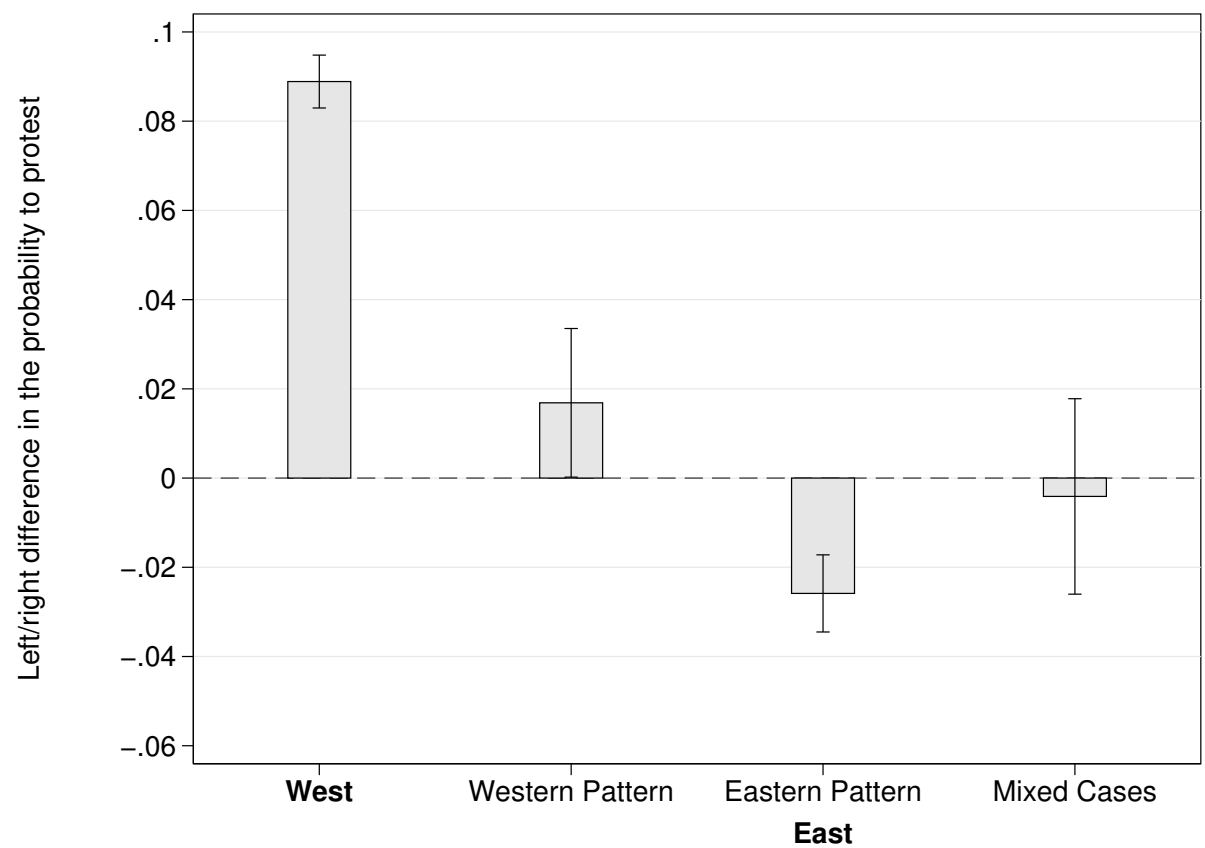

Note: Based on Table 2. Average marginal effects with $95 \%$ confidence intervals. Positive values indicate that left-wingers protest more than right-wingers. 
Figure 3: Ideology and Protest Participation by Country
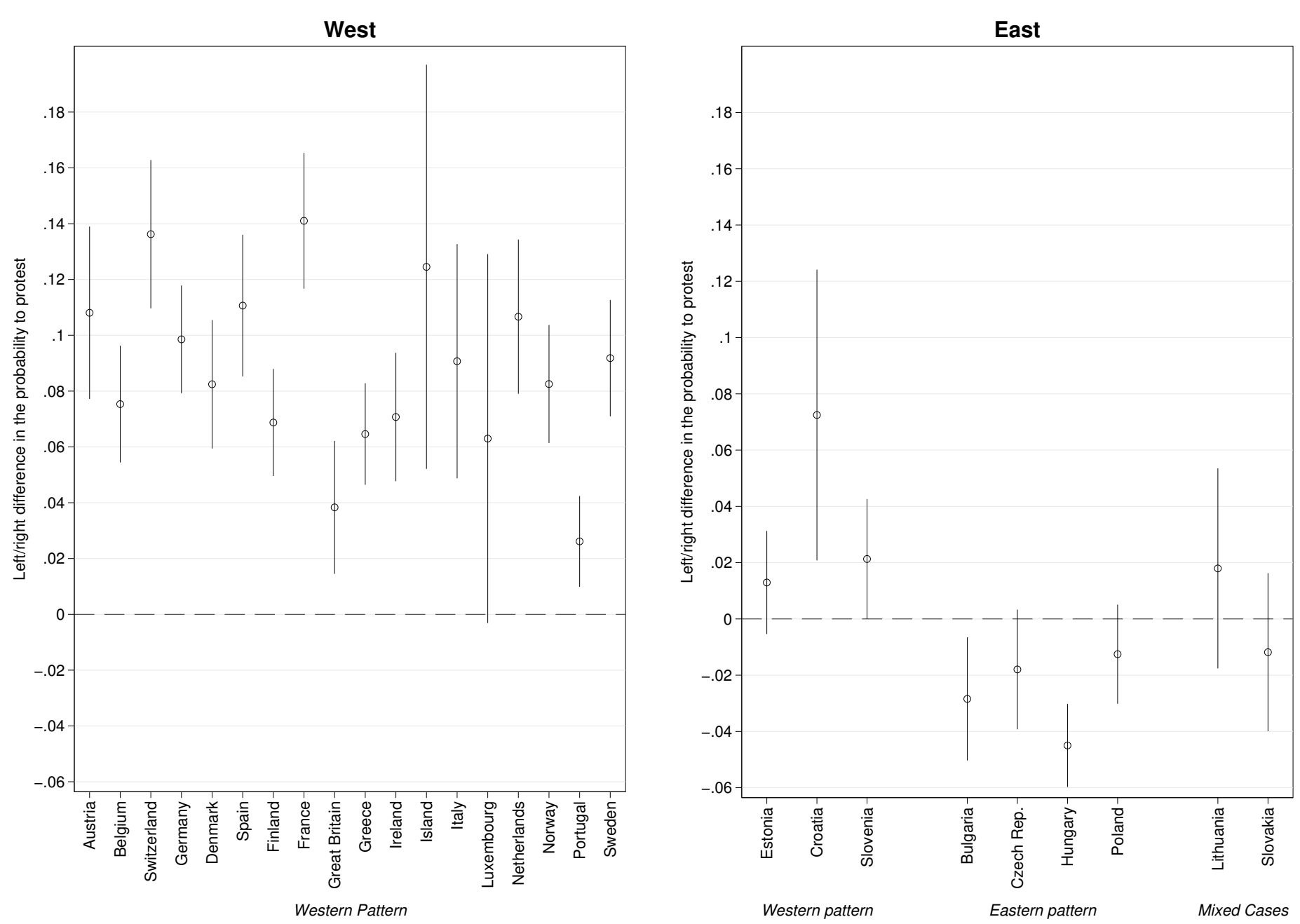

Note: The figure displays the results of the analysis from Table 2 replicated by country (for detailed results, see Tables EA3 to EA5). Average marginal effects with $95 \%$ confidence intervals. Positive values indicate that left-wingers protest more than right-wingers. 
public, Hungary, and Poland), the opposite is true: right-wingers protest more than leftwingers. This provides systematic evidence in favour of Hypothesis $3 .^{28}$ In the Electronic Appendix, we present additional robustness checks of models from Table 2 including alternative operationalizations of the left and the right (continuous left-right scale or special categories for ideological extremists), separate analysis for each type of protest behaviour, and alternative estimation strategies. All of them yield the same substantive findings.

\subsection{Meaning of Ideology: The Role of Cultural Liberalism}

The previous sub-section confirmed that there are distinct groups of post-communist countries that strongly differ in terms of the effect of left-right ideology on protest participation. We now explore whether the difference is due to cultural liberalism as Hypothesis 3 suggests.

We focus on the three main types of countries from the previous analyses (Western, CEE-WP and CEE-EP). We proceed in two stages. In the first analysis, presented in Table 4, we assess whether cultural liberalism predicts protest participation. To do so, we add the continuous variable Cultural liberalism and its interaction with the left-wing dummy to the models presented in the previous sub-section. ${ }^{29}$ This interaction term operationalizes the possibility that the relationship between ideology and protesting is conditioned by the broader context of political competition (see also Federico et al., 2017). It reflects our expectation that culturally liberal right-wingers are more active protesters than culturally conservative left-wingers. We expect that that the effect of cultural liberalism is stronger for those individuals whose positions reflect the ideological clustering in their respective political system. For ease of interpretation, we plot the results from Table 4 in Figure 4.

The figure shows that in all three types of countries cultural liberalism is positively associated with protesting. What differs is, however, how cultural liberalism interacts with left-right ideology. In Western Europe and in CEE-WP, the slope is significantly steeper (i.e. the effect on protesting is stronger) for left-wingers than right-wingers. In those countries, culturally conservative left-wingers are not more but less likely to protest than their right-wing counterparts that are equally conservative. This reveals that the positive effect of left-wing ideology in Western Europe and in CEE-WP is mainly driven by cultural liberalism.

\footnotetext{
${ }^{28}$ In Poland and Estonia, the average marginal effect is not statistically significant at the conventional levels (though by a relatively short margin, $\mathrm{p}<.17$ ). We believe that this is probably due to a smaller pool of protestors in those countries (approximately $11 \%$ of each country's sample) when compared to the other post-communist countries where the relationship is significant ( $15 \%$ of protestors on average). This difference in the overall degree of protest activity means that, with the same sample size and the same intensity of the relationship between ideology and protesting, the probability to observe no relationship by chance is significantly higher in Poland and Estonia than in the other countries.

${ }^{29}$ For parsimony and easier interpretation, we removed centrists (those who scored 5 on the continuous left-right scale) from the analysis.
} 
Table 3: Left-Wing Ideology, Cultural Liberalism and Protesting

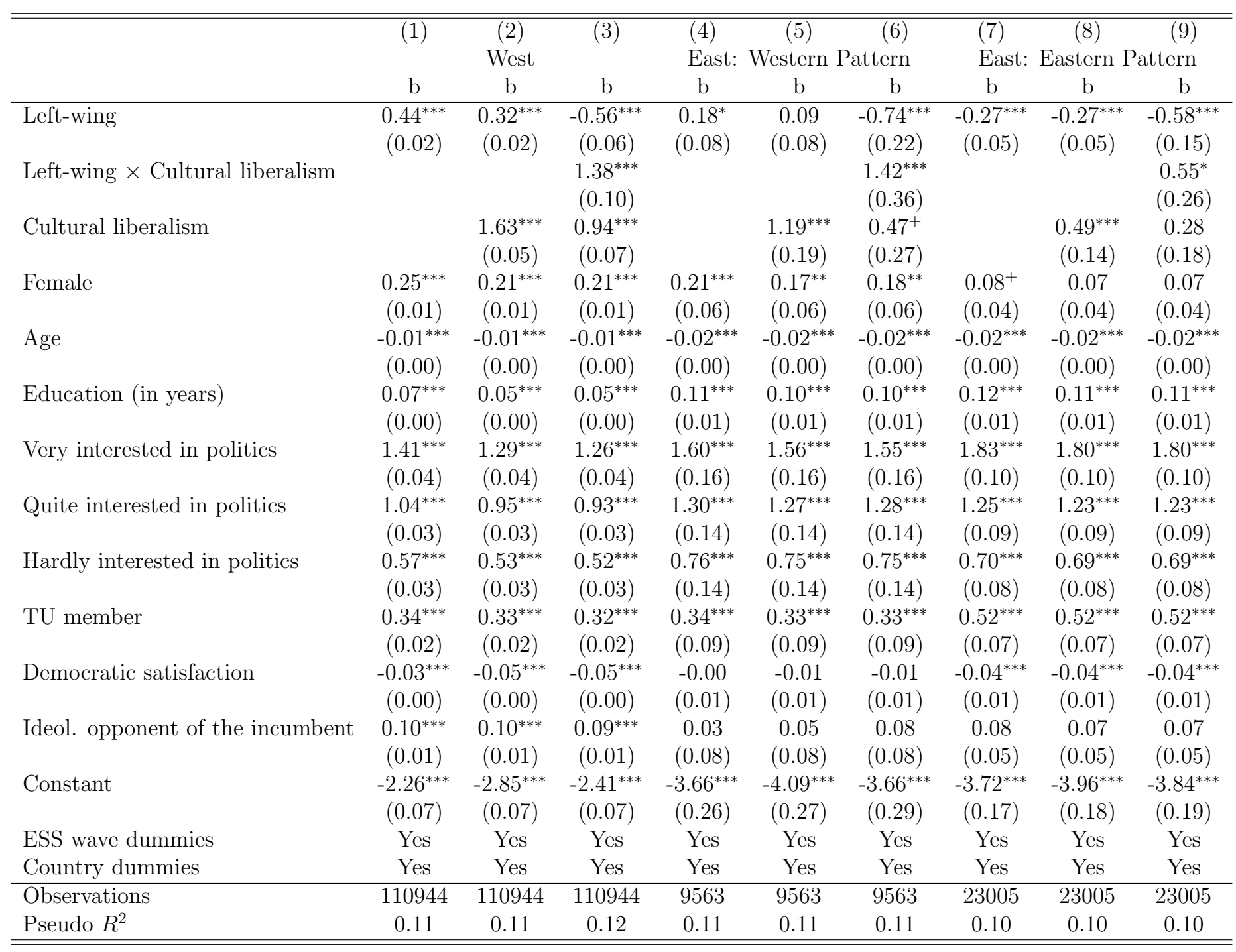

Note: Logistic regressions. Robust standard errors in parentheses. Significance levels: $+p<0.1,{ }^{*} p<0.05,{ }^{* *} p<0.01,{ }^{* * *} p<0.001$. 
Figure 4: The Effect of Cultural Liberalism
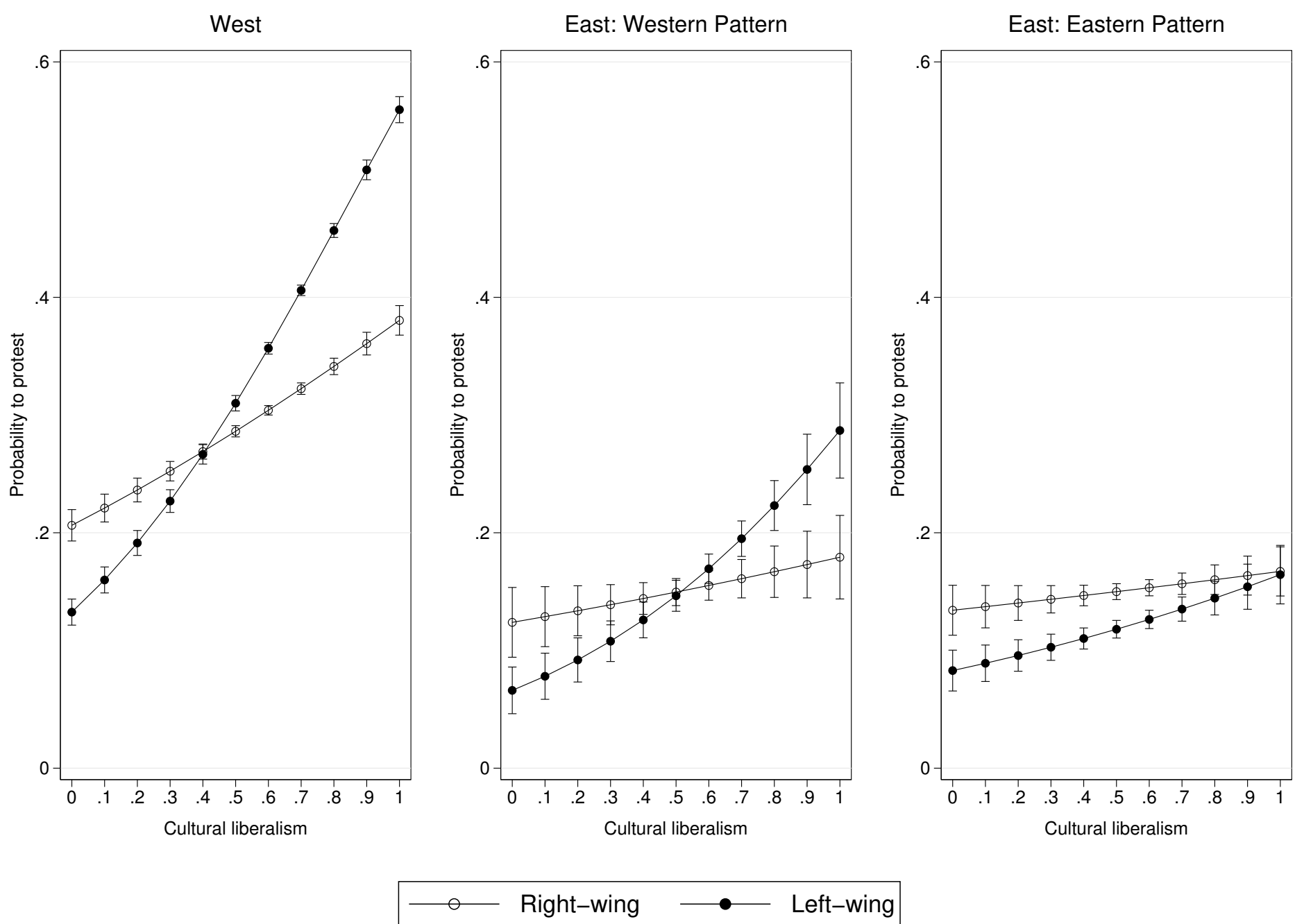

Note: Based on Table 4. $95 \%$ confidence intervals. 
In contrast, in CEE-EP, the difference in the positive effect of cultural liberalism on protesting between the left and the right is much smaller. ${ }^{30}$ In those countries, liberal right-wingers participate as much as liberal left-wingers and, therefore, cultural liberalism does not overcome the effect of the democratization legacy that is favourable to rightwingers' protest participation.

In the Electronic Appendix (Table EA12 and Figures EA1 \& EA2), we present additional analyses using, instead of the dichotomous left-right distinction, the continuous left-right scale ${ }^{31}$ and support for redistribution. The results remain substantively the same. First, they confirm the contrasting patterns between WE and CEE-WP on the one hand, and CEE-EP on the other. Second, they validate the greater propensity to protest of culturally liberal right-wingers (who oppose redistribution) when compared with culturally conservative left-wingers (who support redistribution).

So far, we have learned that cultural liberalism is the key driver of the relationship between ideology and protest behaviour in all regions. What remains to be explained is why it interacts more strongly with left-wing ideology in WE and CEE-WP countries, and less so in CEE-EP countries. Hypothesis 3 expects that this is due to different patterns of political competition and clustering between economic and cultural ideological attitudes. While in WE and CEE-WP countries, the left should be culturally more liberal, in CEEEP it should be more conservative. We explore the validity of this expectation through OLS regression analyses presented in Table 5, which regress the continuous left-right scale $^{32}$ on cultural and economic attitudes. The odd models test a linear version of the relationships (Models 1, 3, 5) while the even models $(2,4,6)$ allow for a curvilinear function by adding a squared form of cultural liberalism and support for redistribution.

Both model specifications support Hypothesis 3. While left-right ideology is strongly positively correlated with support for the reduction of income inequalities everywhere, the association with cultural liberalism varies. According to the linear models, the leftright scale is negatively correlated with cultural liberalism in Western Europe, as well as in CEE-WP countries. In contrast, the relationship between the left-right scale and

\footnotetext{
${ }^{30}$ The difference in the slope becomes statistically and substantively insignificant when Hungary is excluded from the analysis (see the results of an additional analysis plotted in Figure EA3 in the Electronic Appendix). In Hungary, cultural liberalism plays an ambiguous role, which is unparalleled in any other country. While, like in most other countries, cultural liberalism boosts protest-participation among leftwingers, it decreases participation among right-wingers. As a result, among culturally liberal individuals, it makes no difference for protesting whether once is left-wing or right-wing. However, among culturally conservative Hungarians, right-wingers protest much more than left-wingers. Culturally conservative right-wingers are, in fact, the most active group. This is presumably due to the augmented activism of radical right groups, which, among other actions, emulate the mobilization of paramilitary militias and extremist groupings from the interwar period. In the graphic representation of EP countries in Figure 6, Hungary's idiosyncratic relationship reduces the slope of the effect of cultural liberalism on right-wingers and, in consequence, makes look the effect stronger on the left.

${ }^{31}$ It could be objected that the interaction effects in Table 4 may translate the position on the left-right scale (as ideology is operationalized through a dummy variable). Our replication with the continuous left-right scale demonstrates that this is not the case.

${ }^{32}$ For presentation purposes, we divide the original 0-10 left-right scale by 10 .
} 
Table 4: Analysis of Left-Right Scale

\begin{tabular}{|c|c|c|c|c|c|c|}
\hline & (1) & $(2)$ & \multirow{3}{*}{$\begin{array}{c}(3) \\
\text { East: } \mathrm{W}\end{array}$} & $(4)$ & \multirow{3}{*}{$\begin{array}{c}(5) \\
\text { East: } 1 \\
\text { b }\end{array}$} & \multirow{3}{*}{$\begin{array}{c}(6) \\
\text { Eastern Pattern } \\
\text { b }\end{array}$} \\
\hline & \multicolumn{2}{|c|}{ West } & & Western Pattern & & \\
\hline & $\mathrm{b}$ & $\mathrm{b}$ & & b & & \\
\hline Reduce inequality & $0.173^{* * *}$ & $0.190^{* * *}$ & $0.094^{* * *}$ & $0.085^{* * *}$ & $0.144^{* * *}$ & * $\quad 0.088^{* * *}$ \\
\hline & $(0.002)$ & $(0.006)$ & $(0.008)$ & $(0.020)$ & $(0.006)$ & $(0.014)$ \\
\hline Cultural liberalism & $-0.273^{* * *}$ & $0.199 * * *$ & $-0.166^{* * *}$ & 0.092 & $0.028^{* *}$ & $0.221^{* * *}$ \\
\hline & $(0.003)$ & $(0.018)$ & $(0.011)$ & $(0.051)$ & $(0.009)$ & $(0.038)$ \\
\hline Reduce inequality $\times$ Reduce inequality & & $-0.024^{* * *}$ & & 0.012 & & $0.070^{* * *}$ \\
\hline & & $(0.007)$ & & $(0.025)$ & & $(0.017)$ \\
\hline Cultural liberalism $\times$ Cultural liberalism & & $-0.408^{* * *}$ & & $-0.253^{* * *}$ & & $-0.188^{* * *}$ \\
\hline & & $(0.015)$ & & $(0.048)$ & & $(0.036)$ \\
\hline Constant & $0.578^{* * *}$ & $0.452^{* * *}$ & $0.589^{* * *}$ & $0.531^{* * *}$ & $0.418^{* * *}$ & $0.380^{* * *}$ \\
\hline & $(0.003)$ & $(0.006)$ & $(0.009)$ & $(0.015)$ & $(0.008)$ & $(0.011)$ \\
\hline ESS wave dummies & Yes & Yes & Yes & Yes & Yes & Yes \\
\hline Country dummies & Yes & Yes & Yes & Yes & Yes & Yes \\
\hline Observations & 168730 & 168730 & 16841 & 16841 & 35098 & 35098 \\
\hline$R^{2}$ & 0.115 & 0.121 & 0.045 & 0.047 & 0.035 & 0.036 \\
\hline
\end{tabular}

Note: OLS regressions. Robust standard errors in parentheses. Significance levels: $+p<0.1,{ }^{*} p<0.05,{ }^{* *} p<0.01,{ }^{* * *} p<0.001$.

cultural liberalism is positive in CEE-EP countries. Both the magnitude of the regression coefficients from the odd models, and the visualization of the results from the even models presented in Figure 5 demonstrate that the relationship between the left-right scale and cultural liberalism is the strongest in the West and the weakest in CEE-EP countries. In the latter group, cultural liberalism discriminates relatively weekly in terms of left-right ideology. This clarifies why, in most of these countries, cultural liberalism has a similar effect on protest participation of both left-wingers and right-wingers. On the contrary, in Western Europe and, to a lesser extent in the CEE-EP countries, the relationship is strong, presenting more coherent ideological packaging of the economic and cultural dimensions. Consequently, the association between cultural liberalism and protesting is much more natural on the left than on the right. 
Figure 5: Left-Right Ideology: Economic and Cultural Attitudes
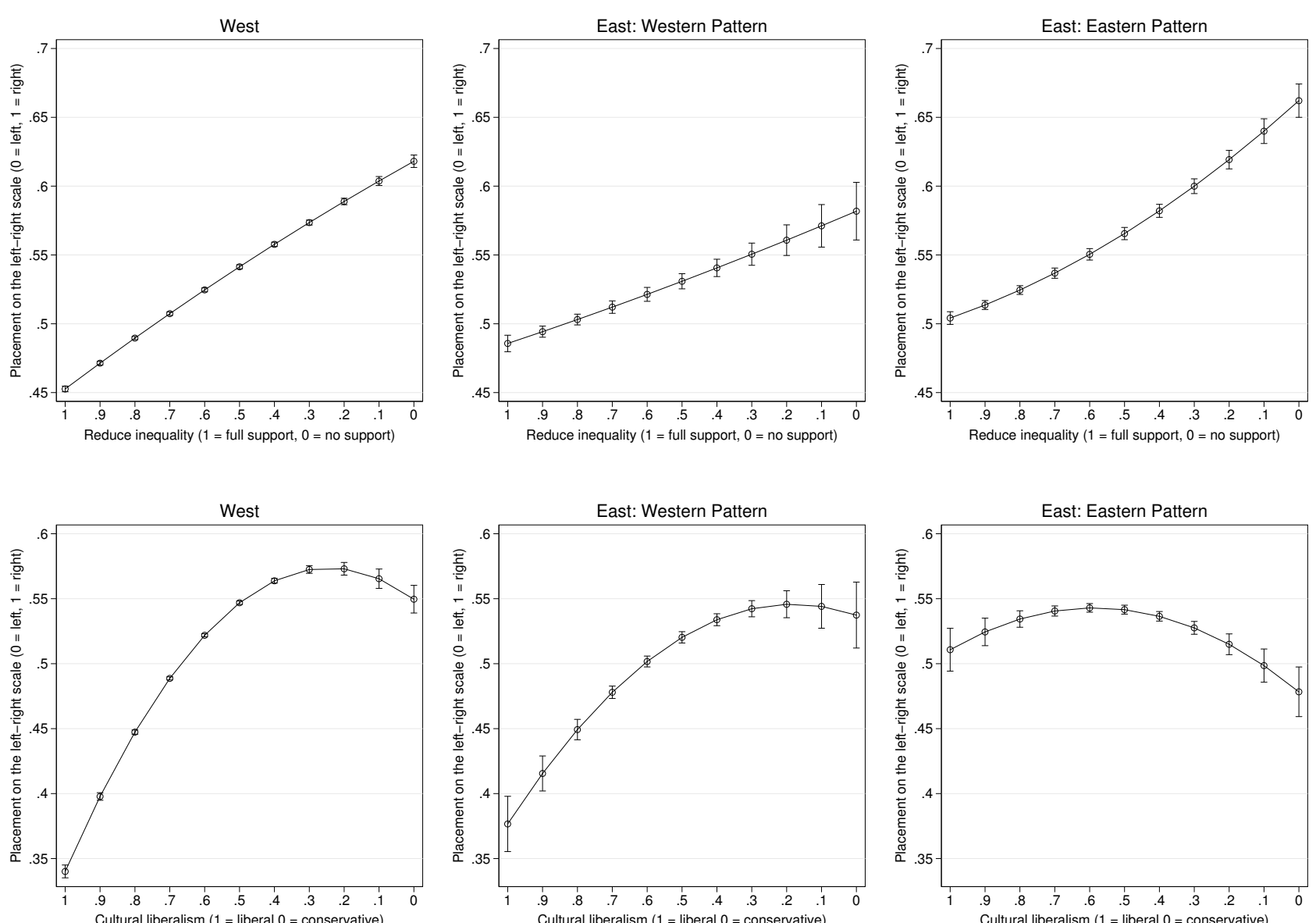

Note: Based on Table 4. $95 \%$ confidence intervals. The orientation of X-axes ensures that, in the West, culturally liberal and economically redistributive attitudes match left-wing positions on the left-right scale. 


\section{Conclusion}

This article addressed the relationship between ideology and protest participation in established and new democracies. By extending our sample beyond established democracies to countries with more diverse ideological patterning, the article disentangles three arguments proposed by the prominent works in the field: one focusing on historical legacies, one on general left-right ideology, and one on cultural liberalism. While these coincide in Western Europe, where the left historically challenged the established order, while furthering economic egalitarianism and cultural liberalism, they differ across Eastern European countries. By bringing these cases into the analysis, this article highlights the particular role of historical legacies and the cultural domain as the driving mechanisms for protest participation in old and new democracies alike.

Our theory and analyses demonstrate that it is not the left, primarily defined in economic terms, that engenders protest. Instead, we isolate the importance, and complementary role of two remaining ideology-related factors: historical legacy, which principally reflects the initial context in which protest participation emerged, and cultural liberalism.

First, in terms of historical legacy, our findings show that those forces that challenge the pre-democratic order and bring about democratization become associated with protest activity. In the East, with its historical legacy of democratization from communist dictatorship, protesting is positively associated with right-wing ideology in the early years of democracy - an outcome we attribute to the right's role in opposing communist rule. Over time, the role of this historical legacy nevertheless weakens, and the cultural component of left-right ideology comes to the forefront as the decisive ideological factor behind protest participation. In the West, the two factors overlap and protest participation has been consistently and strongly positively associated with left-wing ideology thanks to the left's historical association both with alternative forms of political participation, and cultural liberalism.

Second, cultural liberalism is the primary driver of protest participation. In those countries where cultural liberalism associates with the left, protesting is more common among left-wingers, be it in the West or in the East. In those post-communist democracies, where cultural liberalism is not associated with the left, but (albeit more weakly) with the right, cultural liberalism preserves the initial effect of the historical legacy and right-wingers participate in protest more than left-wingers.

With these analyses, the present article contributes to our understanding of individual political behavior, by underlining the ideological basis of protest participation. It provides a general theory of the ideology-participation nexus that can be applied to other democratic regions.

This article also underlines the importance of dimensional considerations that unpack the meaning of the general left-right divide. It shows that considering the particular 
packaging of economic and cultural issues may be of vital importance not only for party competition but also for political participation.

Finally, this article provides further documentation of ideological structuration of East European politics and the importance of historical legacies (e.g. Kitschelt, Mansfeldova, Markowski, and Toka, 1999; Ekiert and Hanson, 2003; Wittenberg, 2015; Pop-Eleches and Tucker, 2017). Far from being a tabula rasa (Kitschelt, 1992), East European politics have been, and continue to be underpinned by consistent ideological patterning. While in the early years of post-communist democracy it was the (anti-communist) right that tended to fuel political protests, later years gave way to political protest being associated with culturally liberal outlooks, no matter which side of the political spectrum espoused them. Protest participation in the East and West is thus continuously ideologically enveloped.

\section{References}

Abadie, A., Athey, S., Imbens, G., \& Wooldridge, J. (2017). When Should You Adjust Standard Errors for Clustering? arXiv:1710.02926 [econ, math, stat]. Retrieved February 8, 2018, from http://arxiv.org/abs/1710.02926

Achen, C. H. \& Bartels, L. M. (2017). Democracy for Realists: Why Elections Do Not Produce Responsive Government. Princeton: Princeton University Press.

Ai, C. \& Norton, E. C. (2003). Interaction terms in logit and probit models. Economics Letters, 80 (1), 123-129. doi:10.1016/S0165-1765(03)00032-6

Bakker, R., Jolly, S., \& Polk, J. (2012). Complexity in the european party space: Exploring dimensionality with experts. European Union Politics, 13(2), 219-245. doi:10.1177/ 1465116512436995

Bakker, R., De Vries, C., Edwards, E., Hooghe, L., Jolly, S., Marks, G., .. Vachudova, M. A. (2015). Measuring party positions in europe: The chapel hill expert survey trend file, 1999-2010. Party Politics, 21 (1), 143-152.

Barnes, S. H. \& Simon, J. (1998). The postcommunist citizen. Budapest: Erasmus Foundation.

Barnes, S. H., Kaase, M., Allerbeck, K. R., Farah, B. G., Heunks, F., Inglehart, R., ... Rosenmayr, L. (1979). Political action : Mass participation in five western democracies. Beverly Hills, Calif. : Sage Publications.

Bartus, T. (2005). Estimation of marginal effects using margeff. The Stata Journal, 5 (3), 309-329.

Bernhagen, P. \& Marsh, M. (2007). Voting and protesting: Explaining citizen participation in old and new european democracies. Democratization, $14(1)$, 44-72. doi:10. $1080 / 13510340601024298$ 
Blais, A., Blake, D., \& Dion, S. (1993). Do parties make a difference? parties and the size of government in liberal democracies. American Journal of Political Science, 37(1), 40-62. doi:10.2307/2111523

Careja, R. \& Emmenegger, P. (2009). The politics of public spending in post-communist countries. East European Politics ES Societies, 23(2), 165-184. doi:10.1177/0888325408328748

Clark, W. R., Golder, M., \& Golder, S. N. (2002). Fiscal policy and the democratic process in the european union. European Union Politics, 3(2), 205-230. doi:10. $1177 / 1465116502003002004$

Coffé, H. \& Lippe, T. v. d. (2010). Citizenship norms in eastern europe. Social Indicators Research, 96 (3), 479-496. doi:10.1007/s11205-009-9488-8

Dalton, R. J. (1988). Citizen politics in western democracies: Public opinion and political parties in the united states, great britain, west germany, and france. Chatham House Publishers.

Dalton, R. J. (2008). Citizenship norms and the expansion of political participation. Political Studies, 56(1), 76-98. Retrieved April 10, 2012, from http://dx.doi.org/ 10.1111/j.1467-9248.2007.00718.x

Dalton, R. J. (2006). Social Modernization and the End of Ideology Debate: Patterns of Ideological Polarization. Japanese Journal of Political Science, 7(1), 1-22. doi:10. 1017/S1468109905002045

Dalton, R. J. \& Welzel, C. (2014). Political culture and value change. In R. J. Dalton \& C. Welzel (Eds.), The civic culture transformed: From allegiant to assertive citizens (pp. 1-18). New York: Cambridge University Press.

Döring, H. \& Manow, P. (2016). Parliaments and governments database (ParlGov): Information on parties, elections and cabinets in modern democracies. Development version. Retrieved from http://www.parlgov.org/

Ekiert, G. \& Hanson. (2003). Introduction. In G. Ekiert \& S. E. Hanson (Eds.), Capitalism and democracy in central and eastern europe: Assessing the legacy of communist rule (pp. 1-11). Cambridge: Cambridge University Press.

Ekiert, G. \& Kubik, J. (1998). Contentious politics in new democracies: East germany, hungary, poland, and slovakia, 198993. World Politics, 50(4), 547-581. doi:10.1017/ S004388710000736X

ESS. (2016). European Social Survey Cumulative File, ESS 1-7 (Data file edition 1.0). NSD - Norwegian Centre for Research Data.

EVS. (2015). European values study longitudinal data file 1981-2008 (evs 1981-2008) (Version 3.0.0). GESIS Data Archive, Cologne. Retrieved from http://dx.doi.org/ $10.4232 / 1.12253$

Fairfield, T. \& Garay, C. (2017). Redistribution Under the Right in Latin America: Electoral Competition and Organized Actors in Policymaking. Comparative Political Studies, 50(14), 1871-1906. doi:10.1177/0010414017695331 
Federico, C. M., Fisher, E. L., \& Deason, G. (2017). The Authoritarian Left Withdraws from Politics: Ideological Asymmetry in the Relationship between Authoritarianism and Political Engagement. The Journal of Politics, 79(3), 1010-1023. doi:10.1086/ 692126

Grzymala-Busse, A. M. (2002). Redeeming the communist past: The regeneration of communist parties in east central europe. Cambridge University Press.

Gurr, T. R. (1970). Why men rebel. Princenton: Princeton University Press.

Gurin, D., Petry, F., \& Crte, J. (2004). Tolerance, protest and democratic transition: Survey evidence from 13 post-communist countries. European Journal of Political Research, 43(3), 371-395. Retrieved August 28, 2016, from http://onlinelibrary. wiley.com/doi/10.1111/j.1475-6765.2004.00158.x/full

Hooghe, L., Marks, G., \& Wilson, C. J. (2002). Does Left/Right Structure Party Positions on European Integration? Comparative Political Studies, 35(8), 965-989. doi:10. $1177 / 001041402236310$

Hooghe, M. \& Quintelier, E. (2014). Political participation in european countries: The effect of authoritarian rule, corruption, lack of good governance and economic downturn. Comparative European Politics, 12(2), 209-232. doi:10.1057/cep.2013.3

Huntington, S. P. (1991). The third wave: Democratization in the late 20th century. Norman: University of Oklahoma Press.

Hutter, S. \& Kriesi, H. (2013). Movements of the left, movements of the right reconsidered. In J. van Stekelenburg, C. Roggeband, \& B. Klandermans (Eds.), The future of social movement research: Dynamics, mechanisms, and processes (pp. 281-298). Minnesota: University of Minnesota Press. Retrieved from http://www.jstor.org/ stable/10.5749/j.ctt46npj4.20

Inglehart, R. (1990). Culture shift in advanced industrial society. Princenton: Princeton University Press.

Inglehart, R. (1979). Political action: The impact of values, cognitive level, and social background. In Political action : Mass participation in five western democracies (pp. 306-343). Beverly Hills, Calif. : Sage Publications.

Inglehart, R. (1977). Silent revolution: Changing values and political styles among western publics. Princenton: Princeton Univ Press.

Inglehart, R. \& Catterberg, G. (2002). Trends in political action: The developmental trend and the post-honeymoon decline. International Journal of Comparative Sociology, 43(3), 300-316. doi:10.1177/002071520204300305

Jakobsen, T. G. \& Listhaug, O. (2014). Social change and the politics of protest. In R. J. Dalton \& C. Welzel (Eds.), The civic culture transformed: From allegiant to assertive citizens (pp. 213-239). New York: Cambridge University Press.

Jou, W. \& Dalton, R. J. (2017). Left-Right Orientations and Voting Behavior. Oxford Research Encyclopedia of Politics. doi:10.1093/acrefore/9780190228637.013.581 
Jowitt, K. (1992). New world disorder: The leninist extinction. Berkeley: University of California Press.

Karaca-Mandic, P., Norton, E. C., \& Dowd, B. (2012). Interaction Terms in Nonlinear Models. Health Services Research, 47(1), 255-274. doi:10.1111/j.1475-6773.2011. 01314.x

Kitschelt, H. (1992). The formation of party systems in east central europe. Politics $\&$ Society, 20(1), 7-50. doi:10.1177/0032329292020001003

Kitschelt, H. (1994). The Transformation of European Social Democracy. Cambridge: Cambridge University Press.

Kitschelt, H., Mansfeldova, Z., Markowski, R., \& Toka, G. (1999). Post-communist party systems: Competition, representation, and inter-party cooperation. Cambridge: Cambridge University Press.

Klingemann, H.-D. (1979). Ideological conceptualization and political action. In Political action: Mass participation in five western democracies (pp. 279-304). Beverly Hills, Calif. : Sage Publications.

Klingemann, H.-D. \& Toka, G. (1998). 1994 hungarian election - post-election study 1994. GESIS Data Archive, ZA3057 Data file Version 1.0.0.

Klingemann, H.-D., Fuchs, D., \& Zielonka, J. (2006). Introduction: Support for democracy and autocracy in eastern europe. In H.-D. Klingemann, D. Fuchs, \& J. Zielonka (Eds.), Democracy and political culture in eastern europe (pp. 1-22). Routledge.

Kopstein, J. (2003). Postcommunist Democracy: Legacies and Outcomes. Comparative Politics, 35(2), 231-250. doi:10.2307/4150153

Kostelka, F. (2017). Does democratic consolidation lead to a decline in voter turnout? global evidence since 1939. American Political Science Review, 111(4), 653-667. doi:10.1017/S0003055417000259

Kostelka, F. (2014). The state of political participation in post-communist democracies: Low but surprisingly little biased citizen engagement. Europe-Asia Studies, 66 (6), 945-968. doi:10.1080/09668136.2014.905386

Kostelka, F. (2015). To mobilise and demobilise: The puzzling decline of voter turnout in post-communist democracies (Doctoral dissertation, Paris, Institut d'tudes politiques). Retrieved April 22, 2016, from http://www.theses.fr/2015IEPP0022

Kuran, T. (1991). Now out of never: The element of surprise in the east european revolution of 1989. World Politics, 44 (1), 7-48. doi:10.2307/2010422

Letki, N. (2004). Socialization for participation? trust, membership, and democratization in east-central europe. Political Research Quarterly, 57(4), 665-679. doi:10.2307/ 3219827

Marks, G., Hooghe, L., Nelson, M., \& Edwards, E. (2006). Party competition and european integration in the east and west different structure, same causality. Comparative Political Studies, 39(2), 155-175. doi:10.1177/0010414005281932 
Marsh, A. (1977). Protest and political consciousness. Beverly Hills, Calif.: Sage Publications.

Mason, D. S. (1995). Attitudes toward the market and political participation in the postcommunist states. Slavic Review, 54 (2), 385-406. Retrieved December 29, 2012, from http://works.bepress.com/david_mason/44

Mayer, N. (2004). Le temps des manifestations. Revue europenne des sciences sociales. European Journal of Social Sciences, XLII-129, 219-224. doi:10.4000/ress.410

Mayer, N. (2010). Sociologie des comportements politiques. Paris: Armand Colin.

Mayer, N. \& Perrineau, P. (1992). Les comportements politiques. Paris: A. Colin.

McCarthy, J. D. \& Zald, M. N. (1977). Resource mobilization and social movements: A partial theory. American Journal of Sociology, 82(6), 1212-1241. Retrieved July 24, 2016, from http://www.jstor.org/stable/2777934

Meer, T. W.G.v. d., Deth, J. W. v., \& Scheepers, P. L. H. (2009). The Politicized Participant: Ideology and Political Action in 20 Democracies. Comparative Political Studies, 42(11), 1426-1457. doi:10.1177/0010414009332136

Miller, R. F. (1992). Concluding essay. In The development of civil society in communist systems (pp. 130-147). Sydney: Allen \& Unwin.

Mokken, R. J. (1971). A Theory and Procedure of Scale Analysis, With Applications in Political Research (Reprint 2011). Berlin, Boston: De Gruyter Mouton. doi:10.1515/ 9783110813203

Mood, C. (2010). Logistic regression: Why we cannot do what we think we can do, and what we can do about it. European Sociological Review, 26(1), 67-82. doi:10.1093/ esr /jcp006

Norris, P. (2002). Democratic phoenix: Reinventing political activism. Cambridge: Cambridge University Press.

Nový, M. (2014). Electoral and non-electoral participation in the visegrad countries complements or substitutes? East European Politics 8 Societies, 28(4), 863-886. doi:10. $1177 / 0888325414532496$

O’Donnell, G. \& Schmitter, P. C. (1986). Transitions from authoritarian rule, vol. 4: Tentative conclusions about uncertain democracies. Baltimore: The Johns Hopkins University Press.

Polk, J., Rovny, J., Bakker, R., Edwards, E., Hooghe, L., Jolly, S., .. Zilovic, M. (2017). Explaining the salience of anti-elitism and reducing political corruption for political parties in europe with the 2014 chapel hill expert survey data. Research $\&$ Politics, 4 (1), 1-9. doi:10.1177/2053168016686915

Pop-Eleches, G. \& Tucker, J. A. (2010). After the party: Legacies and left-right distinctions in post-communist countries. The 2010 American Political Science Association Meeting. Washington, D.C. 
Pop-Eleches, G. \& Tucker, J. A. (2013). Associated with the past? communist legacies and civic participation in post-communist countries. East European Politics ES Societies, 27(1), 45-68. doi:10.1177/0888325412465087

Pop-Eleches, G. \& Tucker, J. A. (2017). Communism's Shadow: Historical Legacies and Contemporary Political Attitudes. Google-Books-ID: yUtaDgAAQBAJ. Princenton: Princeton University Press.

Quaranta, M. (2015). Political Protest in Western Europe: Exploring the Role of Context in Political Action. Springer.

Rosenstone, S. J. \& Hansen, J. M. (1993). Mobilization, participation, and democracy in america. New York: Longman.

Rovny, J. (2014). Communism, federalism, and ethnic minorities: Explaining party competition patterns in eastern europe. World Politics, 66 (4), 669-708. doi:10.1017/ S0043887114000227

Rovny, J. (2015). Party competition structure in eastern europe aggregate uniformity versus idiosyncratic diversity? East European Politics \& Societies, 29(1), 40-60. doi:10.1177/0888325414567535

Rovny, J. \& Edwards, E. E. (2012). Struggle over dimensionality party competition in western and eastern europe. East European Politics 6 Societies, 26(1), 56-74. doi:10.1177/0888325410387635

Rucht, D. (2007). 38. the spread of protest politics. In R. J. Dalton \& H.-D. Klingemann (Eds.), The oxford handbook of political behavior (1st ed., Vol. 1, pp. 708-720). Oxford, England: Oxford University Press. Retrieved February 10, 2012, from http: / / www . oxfordhandbooks.com / oso / public/ content/oho_politics / 9780199270125/ oxfordhb-9780199270125-chapter-033.html

Rueschemeyer, D., Stephens, E. H., Huber, E., \& Stephens, J. D. (1992). Capitalist Development and Democracy. Cambridge: University of Chicago Press.

Stockemer, D. (2014). What drives unconventional political participation? a two level study. The Social Science Journal, 51 (2), 201-211. doi:10.1016/j.soscij.2013.10.012

Sztompka, P. (1993). Civilizational incompetence: The trap of post-communist societies. Zeitschrift fr Soziologie, 22(2), 85-95. Retrieved from http://www.zfs-online.org/ index.php/zfs/article/viewFile/2822/2359

Sztompka, P. (1996). Looking back: The year 1989 as a cultural and civilizational break. Communist and Post-Communist Studies, 29(2), 115-129. doi:10.1016 / S0967067X(96)80001-8

Tătar, M. I. (2015). Selective or generic activism? types of participants, political action repertoires and mobilisation capacity in a post-communist society. Europe-Asia Studies, 67(8), 1251-1281. doi:10.1080/09668136.2015.1075191 
Tavits, M. \& Letki, N. (2009). When left is right: Party ideology and policy in postcommunist europe. American Political Science Review, 103(4), 555-569. doi:10. $1017 /$ S0003055409990220

Tilly, C. (1975). Revolutions and collective violence. In F. I. Greenstein \& N. W. Polsby (Eds.), Handbook of political science: Macropolitical theory (Vol. 3, pp. 483-555). Reading: Addison-Wesley.

Tilly, C. (1983). Speaking your mind without elections, surveys, or social movements. The Public Opinion Quarterly, 47(4), 461-478. Retrieved August 29, 2016, from http://www.jstor.org/stable/2748659

Torcal, M., Rodon, T., \& Hierro, M. J. (2016). Word on the street: The persistence of leftist-dominated protest in europe. West European Politics, 39(2), 326-350. doi:10.1080/01402382.2015.1068525

Vachudova, M. A. \& Hooghe, L. (2009). Postcommunist politics in a magnetic field: How transition and EU accession structure party competition on european integration. Comparative European Politics, 7(2), 179-212. doi:10.1057/cep.2008.9

Vanhuysse, P. (2006). Divide and pacify: Strategic social policies and political protests in post-communist democracies. Budapest: Central European University Press.

Verba, S., Schlozman, K. L., \& Brady, H. (1995). Voice and equality: Civic voluntarism in american politics (Abridged edition). Cambridge, Mass: Harvard University Press.

Volkens, A., Lehmann, P., Matthie, T., Merz, N., Regel, S., \& Weels, B. (2018). The manifesto data collection. manifesto project ( $\mathrm{mrg} / \mathrm{cmp} /$ marpor). Wissenschaftszentrum Berlin fr Sozialforschung (WZB).

Vráblíková, K. (2014). How context matters? mobilization, political opportunity structures, and nonelectoral political participation in old and new democracies. Comparative Political Studies, 47(2), 203-229. doi:10.1177/0010414013488538

Vries, C. E. d., Hakhverdian, A., \& Lancee, B. (2013). The dynamics of voters left/right identification: The role of economic and cultural attitudes. Political Science Research and Methods, 1(2), 223-238. doi:10.1017/psrm.2013.4

Wittenberg, J. (2015). Conceptualizing Historical Legacies. East European Politics and Societies, 29(2), 366-378. doi:10.1177/0888325415577864 
These are the Electronic Appendices for the paper "It's not the Left: Ideology and Protest Participation in Old and New Democracies"

\section{Contents}

Regression tables for Figures $1 \& \mathbf{3} \ldots \ldots \ldots \ldots$

Robustness checks: Table $2 \ldots \ldots$. . . . . . . . . . . 7

Continuous L $/ \mathrm{R}$ scale . . . . . . . . . . . . . . . . 7

Demonstrations only . . . . . . . . . . . . . . . . 8

Petitions only . . . . . . . . . . . . . . . . . . 9

Cumulative scale (petitions + demonstrations) . . . . . . . . 10

Controlling for ideological extremism . . . . . . . . . . . . . 11

Clustered standard errors . . . . . . . . . . . . . . . . . . 12

Robustness checks: Table $\mathbf{3}$ and Figure 4 . . . . . . . . . 13

Table 3: Continuous L/R scale, reduction of income inequalities . . 13

Figure 4: Continuous L/R scale . . . . . . . . . . . . . . . . 14

Figure 4: Reduction of income inequalities . . . . . . . . . . . 15

Figure 4: EP without Hungary . . . . . . . . . . . . . 16

Mokken scale analysis . . . . . . . . . . . . . . . 17

Descriptive statistics . . . . . . . . . . . . . . . . . . . 18

EVS data . . . . . . . . . . . . . . . . . . . . . . . . 18

ESS data . . . . . . . . . . . . . . . . . . . . . . 18

Political patterning in Hungary and Poland . . . . . . . . 19 
Table EA1: Evolution of the Effect of Ideology on Protesting 1990-2010 (EVS)

\begin{tabular}{lcc}
\hline \hline & $(1)$ & $(2)$ \\
& West & East \\
& $\mathrm{b}$ & $\mathrm{b}$ \\
\hline Left-wing & $0.60^{* * *}$ & $-0.40^{* * *}$ \\
& $(0.03)$ & $(0.05)$ \\
EVS wave 1999-2001 × Left-wing & -0.06 & $0.47^{* * *}$ \\
& $(0.05)$ & $(0.07)$ \\
EVS wave 2008-2010 × Left-wing & -0.07 & $0.57^{* * *}$ \\
& $(0.05)$ & $(0.06)$ \\
EVS wave 1999-2001 & $0.33^{* * *}$ & $-0.45^{* * *}$ \\
& $(0.03)$ & $(0.04)$ \\
EVS wave 2008-2010 & $0.29^{* * *}$ & $-0.89^{* * *}$ \\
& $(0.03)$ & $(0.04)$ \\
Constant & $-0.40^{* * *}$ & $-0.94^{* * *}$ \\
& $(0.04)$ & $(0.05)$ \\
Country dummies & Yes & Yes \\
\hline Observations & 52683 & 37279 \\
Pseudo $R^{2}$ & 0.06 & 0.07 \\
\hline \hline
\end{tabular}

Note: Logistic regressions. Robust standard errors in parentheses. Significance levels: ${ }^{+} p<0.1,{ }^{*} p<0.05,{ }^{* *} p<0.01,{ }^{* * *} p<0.001$. West: Austria, Belgium, Denmark, Spain, Finland, France, Germany, Great Britain, Ireland, Iceland, Netherlands, Portugal, Sweden. East: Bulgaria, Croatia, Czech Republic, Estonia, Hungary, Latvia, Lithuania, Poland, Romania, Slovakia, Slovenia. 
Table EA2: Evolution of the Effect of Ideology on Protesting 2004-2012 (ESS)

\begin{tabular}{lcc}
\hline \hline & $(1)$ & $(2)$ \\
& West & East \\
& $\mathrm{b}$ & $\mathrm{b}$ \\
\hline Left-wing & $0.62^{* * *}$ & -0.11 \\
& $(0.09)$ & $(0.15)$ \\
ESS wave $4 \times$ Left-wing & -0.18 & -0.07 \\
& $(0.11)$ & $(0.21)$ \\
ESS wave $6 \times$ Left-wing & 0.02 & 0.09 \\
& $(0.08)$ & $(0.23)$ \\
Center & -0.04 & $-0.41^{* *}$ \\
& $(0.05)$ & $(0.15)$ \\
ESS wave $4 \times$ Center & 0.01 & -0.18 \\
& $(0.06)$ & $(0.13)$ \\
ESS wave $6 \times$ Center & 0.02 & 0.08 \\
& $(0.05)$ & $(0.05)$ \\
ESS wave 4 & $0.08^{+}$ & 0.06 \\
ESS wave 6 & $(0.05)$ & $(0.10)$ \\
& -0.05 & 0.11 \\
Constant & $(0.05)$ & $(0.23)$ \\
Country dummies & $-1.20^{* * *}$ & $-1.42^{* * *}$ \\
\hline Observations & $(0.03)$ & $(0.11)$ \\
Pseudo $R^{2}$ & Yes & Yes \\
\hline \hline
\end{tabular}

Note: Logistic regressions. Robust standard errors in parentheses. Significance levels: ${ }^{+} p<0.1,{ }^{*} p<0.05,{ }^{* *} p<0.01,{ }^{* * *} p<0.001$. West: Belgium, Switzerland, Germany, Denmark, Spain, Finland, France, Great Britain, Ireland, Netherlands, Norway, Portugal, Sweden. East: Czech Republic, Estonia, Hungary, Poland, Slovakia, Slovenia. 
Table EA3: Ideology and Protest Participation by Country (West 1)

\begin{tabular}{|c|c|c|c|c|c|c|c|c|c|}
\hline & $\begin{array}{c}(1) \\
\text { Austria } \\
\text { b }\end{array}$ & $\begin{array}{c}(2) \\
\text { Belgium } \\
\text { b }\end{array}$ & $\begin{array}{c}(3) \\
\text { Switzerland } \\
\mathrm{b}\end{array}$ & $\begin{array}{c}(4) \\
\text { Germany } \\
b\end{array}$ & $\begin{array}{c}(5) \\
\text { Denmark } \\
b\end{array}$ & $\begin{array}{c}(6) \\
\text { Spain } \\
b\end{array}$ & $\begin{array}{c}(7) \\
\text { Finland } \\
\text { b }\end{array}$ & $\begin{array}{c}(8) \\
\text { France } \\
\text { b }\end{array}$ & $\begin{array}{c}(9) \\
\text { Great Britain } \\
\text { b }\end{array}$ \\
\hline Left-wing & $\begin{array}{c}0.57^{* * *} \\
(0.08)\end{array}$ & $\begin{array}{c}0.41^{* * *} \\
(0.06)\end{array}$ & $\begin{array}{c}0.62^{* * *} \\
(0.06)\end{array}$ & $\begin{array}{c}0.47^{* * *} \\
(0.05)\end{array}$ & $\begin{array}{c}0.41^{* * *} \\
(0.06)\end{array}$ & $\begin{array}{c}0.57^{* * *} \\
(0.07)\end{array}$ & $\begin{array}{c}0.38^{* * *} \\
(0.05)\end{array}$ & $\begin{array}{c}0.69^{* * *} \\
(0.06)\end{array}$ & $\begin{array}{l}0.18^{* *} \\
(0.06)\end{array}$ \\
\hline Center & $\begin{array}{l}0.16^{+} \\
(0.09)\end{array}$ & $\begin{array}{c}0.06 \\
(0.07)\end{array}$ & $\begin{array}{l}-0.01 \\
(0.06)\end{array}$ & $\begin{array}{c}0.02 \\
(0.05)\end{array}$ & $\begin{array}{c}0.07 \\
(0.06)\end{array}$ & $\begin{array}{l}0.23^{* *} \\
(0.08)\end{array}$ & $\begin{array}{l}0.12^{*} \\
(0.06)\end{array}$ & $\begin{array}{l}0.22^{* *} \\
(0.07)\end{array}$ & $\begin{array}{l}-0.02 \\
(0.06)\end{array}$ \\
\hline Female & $\begin{array}{l}0.18^{* *} \\
(0.07)\end{array}$ & $\begin{array}{c}0.22^{* * *} \\
(0.05)\end{array}$ & $\begin{array}{l}0.13^{* *} \\
(0.05)\end{array}$ & $\begin{array}{c}0.28^{* * *} \\
(0.04)\end{array}$ & $\begin{array}{c}0.46^{* * *} \\
(0.05)\end{array}$ & $\begin{array}{c}0.19^{* * *} \\
(0.05)\end{array}$ & $\begin{array}{c}0.63^{* * *} \\
(0.04)\end{array}$ & $\begin{array}{l}0.16^{* *} \\
(0.05)\end{array}$ & $\begin{array}{c}0.38^{* * *} \\
(0.04)\end{array}$ \\
\hline Age & $\begin{array}{c}-0.01^{* * *} \\
(0.00)\end{array}$ & $\begin{array}{c}-0.02^{* * *} \\
(0.00)\end{array}$ & $\begin{array}{c}-0.01^{* * *} \\
(0.00)\end{array}$ & $\begin{array}{c}-0.01^{* * *} \\
(0.00)\end{array}$ & $\begin{array}{c}-0.03^{* * *} \\
(0.00)\end{array}$ & $\begin{array}{c}-0.01^{* * *} \\
(0.00)\end{array}$ & $\begin{array}{c}-0.03^{* * *} \\
(0.00)\end{array}$ & $\begin{array}{c}-0.01^{* * *} \\
(0.00)\end{array}$ & $\begin{array}{c}-0.00^{* * *} \\
(0.00)\end{array}$ \\
\hline Education (in years) & $\begin{array}{c}0.07^{* * *} \\
(0.01)\end{array}$ & $\begin{array}{c}0.08^{* * *} \\
(0.01)\end{array}$ & $\begin{array}{c}0.08^{* * *} \\
(0.01)\end{array}$ & $\begin{array}{c}0.10^{* * *} \\
(0.01)\end{array}$ & $\begin{array}{c}0.03^{* * *} \\
(0.01)\end{array}$ & $\begin{array}{c}0.06^{* * *} \\
(0.01)\end{array}$ & $\begin{array}{c}0.08^{* * *} \\
(0.01)\end{array}$ & $\begin{array}{c}0.08^{* * *} \\
(0.01)\end{array}$ & $\begin{array}{c}0.06^{* * *} \\
(0.01)\end{array}$ \\
\hline Very interested in politics & $\begin{array}{c}1.55^{* * *} \\
(0.15)\end{array}$ & $\begin{array}{c}1.44^{* * *} \\
(0.10)\end{array}$ & $\begin{array}{c}1.16^{* * *} \\
(0.12)\end{array}$ & $\begin{array}{c}1.32^{* * *} \\
(0.12)\end{array}$ & $\begin{array}{c}1.09^{* * *} \\
(0.16)\end{array}$ & $\begin{array}{c}1.51^{* * *} \\
(0.11)\end{array}$ & $\begin{array}{l}1.11^{* * *} \\
(0.11)\end{array}$ & $\begin{array}{c}1.18^{* * *} \\
(0.10)\end{array}$ & $\begin{array}{c}1.57^{* * *} \\
(0.09)\end{array}$ \\
\hline Quite interested in politics & $\begin{array}{l}1.10^{* * *} \\
(0.14)\end{array}$ & $\begin{array}{c}0.95^{* * *} \\
(0.08)\end{array}$ & $\begin{array}{c}0.84^{* * *} \\
(0.11)\end{array}$ & $\begin{array}{c}1.05^{* * *} \\
(0.11)\end{array}$ & $\begin{array}{c}0.88^{* * *} \\
(0.16)\end{array}$ & $\begin{array}{c}1.26^{* * *} \\
(0.08)\end{array}$ & $\begin{array}{c}0.74^{* * *} \\
(0.09)\end{array}$ & $\begin{array}{c}0.84^{* * *} \\
(0.08)\end{array}$ & $\begin{array}{c}1.13^{* * *} \\
(0.07)\end{array}$ \\
\hline Hardly interested & $\begin{array}{c}0.59^{* * *} \\
(0.14)\end{array}$ & $\begin{array}{c}0.48^{* * *} \\
(0.08)\end{array}$ & $\begin{array}{l}0.35^{* *} \\
(0.11)\end{array}$ & $\begin{array}{c}0.56^{* * *} \\
(0.11)\end{array}$ & $\begin{array}{c}0.54^{* * *} \\
(0.16)\end{array}$ & $\begin{array}{c}0.57^{* * *} \\
(0.07)\end{array}$ & $\begin{array}{c}0.35^{* * *} \\
(0.09)\end{array}$ & $\begin{array}{c}0.34^{* * *} \\
(0.08)\end{array}$ & $\begin{array}{c}0.66^{* * *} \\
(0.08)\end{array}$ \\
\hline TU member & $\begin{array}{c}0.27^{* * *} \\
(0.07)\end{array}$ & $\begin{array}{c}0.17^{* * *} \\
(0.05)\end{array}$ & $\begin{array}{c}0.60^{* * *} \\
(0.07)\end{array}$ & $\begin{array}{c}0.41^{* * *} \\
(0.05)\end{array}$ & $\begin{array}{l}0.14^{* *} \\
(0.05)\end{array}$ & $\begin{array}{c}0.64^{* * *} \\
(0.08)\end{array}$ & $\begin{array}{c}0.04 \\
(0.04)\end{array}$ & $\begin{array}{c}1.08^{* * *} \\
(0.09)\end{array}$ & $\begin{array}{c}0.40^{* * *} \\
(0.06)\end{array}$ \\
\hline Democratic satisfaction & $\begin{array}{c}-0.03^{*} \\
(0.01)\end{array}$ & $\begin{array}{l}-0.00 \\
(0.01)\end{array}$ & $\begin{array}{l}-0.01 \\
(0.01)\end{array}$ & $\begin{array}{c}-0.02^{* *} \\
(0.01)\end{array}$ & $\begin{array}{l}-0.03^{*} \\
(0.01)\end{array}$ & $\begin{array}{c}-0.06^{* * *} \\
(0.01)\end{array}$ & $\begin{array}{l}-0.03^{*} \\
(0.01)\end{array}$ & $\begin{array}{c}-0.04^{* * *} \\
(0.01)\end{array}$ & $\begin{array}{c}-0.03^{* * *} \\
(0.01)\end{array}$ \\
\hline Ideological opponent of the incumbent cabinet & $\begin{array}{c}0.00 \\
(.)\end{array}$ & $\begin{array}{c}0.05 \\
(0.06)\end{array}$ & $\begin{array}{c}0.02 \\
(0.06)\end{array}$ & $\begin{array}{c}0.03 \\
(0.05)\end{array}$ & $\begin{array}{c}0.19^{* * *} \\
(0.06)\end{array}$ & $\begin{array}{l}0.19^{* *} \\
(0.07)\end{array}$ & $\begin{array}{l}0.16^{* *} \\
(0.05)\end{array}$ & $\begin{array}{l}0.12^{+} \\
(0.06)\end{array}$ & $\begin{array}{l}0.09^{+} \\
(0.05)\end{array}$ \\
\hline Constant & $\begin{array}{c}-2.34^{* * *} \\
(0.23)\end{array}$ & $\begin{array}{c}-1.88^{* * *} \\
(0.17)\end{array}$ & $\begin{array}{c}-1.60^{* * *} \\
(0.18)\end{array}$ & $\begin{array}{c}-2.69^{* * *} \\
(0.16)\end{array}$ & $\begin{array}{c}-1.10^{* * *} \\
(0.21)\end{array}$ & $\begin{array}{c}-1.65^{* * *} \\
(0.19)\end{array}$ & $\begin{array}{c}-1.56^{* * *} \\
(0.17)\end{array}$ & $\begin{array}{c}-1.80^{* * *} \\
(0.17)\end{array}$ & $\begin{array}{c}-1.93^{* * *} \\
(0.15)\end{array}$ \\
\hline ESS wave dummies & Yes & Yes & Yes & Yes & Yes & Yes & Yes & Yes & Yes \\
\hline Observations & 6469 & 10397 & 9582 & 17063 & 9398 & 8419 & 12200 & 10929 & 12626 \\
\hline Pseudo $R^{2}$ & 0.07 & 0.08 & 0.07 & 0.07 & 0.07 & 0.12 & 0.11 & 0.11 & 0.07 \\
\hline
\end{tabular}

Note: Logistic regressions. Robust standard errors in parentheses. Significance levels: ${ }^{+} p<0.1,{ }^{*} p<0.05,{ }^{* *} p<0.01,{ }^{* * *} p<0.001$. 
Table EA4: Ideology and Protest Participation by Country (West 2)

\begin{tabular}{|c|c|c|c|c|c|c|c|c|c|}
\hline & $\begin{array}{c}(1) \\
\text { Greece } \\
\text { b }\end{array}$ & $\begin{array}{c}(2) \\
\text { Ireland } \\
\text { b }\end{array}$ & $\begin{array}{c}(3) \\
\text { Island } \\
\text { b }\end{array}$ & $\begin{array}{c}(4) \\
\text { Italy } \\
\text { b }\end{array}$ & $\begin{array}{c}(5) \\
\text { Luxembourg } \\
b\end{array}$ & $\begin{array}{c}(6) \\
\text { Netherlands } \\
b\end{array}$ & $\begin{array}{c}(7) \\
\text { Norway } \\
\text { b }\end{array}$ & $\begin{array}{c}(8) \\
\text { Portugal } \\
\text { b }\end{array}$ & $\begin{array}{c}(9) \\
\text { Sweden } \\
\text { b }\end{array}$ \\
\hline Left-wing & $\begin{array}{c}0.82^{* * *} \\
(0.12)\end{array}$ & $\begin{array}{c}0.39^{* * *} \\
(0.07)\end{array}$ & $\begin{array}{c}0.54^{* * *} \\
(0.16)\end{array}$ & $\begin{array}{c}0.55^{* * *} \\
(0.13)\end{array}$ & $\begin{array}{l}0.30^{+} \\
(0.16)\end{array}$ & $\begin{array}{c}0.60^{* * *} \\
(0.08)\end{array}$ & $\begin{array}{c}0.37^{* * *} \\
(0.05)\end{array}$ & $\begin{array}{l}0.34^{* *} \\
(0.11)\end{array}$ & $\begin{array}{c}0.39^{* * *} \\
(0.05)\end{array}$ \\
\hline Center & $\begin{array}{c}0.01 \\
(0.14)\end{array}$ & $\begin{array}{l}-0.03 \\
(0.06)\end{array}$ & $\begin{array}{c}0.15 \\
(0.18)\end{array}$ & $\begin{array}{c}0.14 \\
(0.15)\end{array}$ & $\begin{array}{c}0.13 \\
(0.15)\end{array}$ & $\begin{array}{l}0.12^{+} \\
(0.07)\end{array}$ & $\begin{array}{c}0.02 \\
(0.06)\end{array}$ & $\begin{array}{c}0.01 \\
(0.14)\end{array}$ & $\begin{array}{l}0.18^{* *} \\
(0.06)\end{array}$ \\
\hline Female & $\begin{array}{l}0.17^{+} \\
(0.10)\end{array}$ & $\begin{array}{c}0.27^{* * *} \\
(0.05)\end{array}$ & $\begin{array}{c}0.30^{*} \\
(0.14)\end{array}$ & $\begin{array}{c}0.04 \\
(0.10)\end{array}$ & $\begin{array}{l}-0.08 \\
(0.13)\end{array}$ & $\begin{array}{c}0.27^{* * *} \\
(0.05)\end{array}$ & $\begin{array}{c}0.25^{* * *} \\
(0.04)\end{array}$ & $\begin{array}{c}-0.33^{* * *} \\
(0.09)\end{array}$ & $\begin{array}{c}0.29^{* * *} \\
(0.04)\end{array}$ \\
\hline Age & $\begin{array}{c}-0.02^{* * *} \\
(0.00)\end{array}$ & $\begin{array}{c}-0.02^{* * *} \\
(0.00)\end{array}$ & $\begin{array}{c}-0.02^{* * *} \\
(0.00)\end{array}$ & $\begin{array}{c}-0.02^{* * *} \\
(0.00)\end{array}$ & $\begin{array}{c}-0.01^{* * *} \\
(0.00)\end{array}$ & $\begin{array}{c}-0.01^{* * *} \\
(0.00)\end{array}$ & $\begin{array}{c}-0.02^{* * *} \\
(0.00)\end{array}$ & $\begin{array}{l}-0.01^{*} \\
(0.00)\end{array}$ & $\begin{array}{c}-0.01^{* * *} \\
(0.00)\end{array}$ \\
\hline Education (in years) & $\begin{array}{c}0.09^{* * *} \\
(0.01)\end{array}$ & $\begin{array}{c}0.06^{* * *} \\
(0.01)\end{array}$ & $\begin{array}{c}0.01 \\
(0.02)\end{array}$ & $\begin{array}{c}0.05^{* * *} \\
(0.01)\end{array}$ & $\begin{array}{c}0.06^{* * *} \\
(0.02)\end{array}$ & $\begin{array}{c}0.07^{* * *} \\
(0.01)\end{array}$ & $\begin{array}{l}0.04^{* * *} \\
(0.01)\end{array}$ & $\begin{array}{c}0.14^{* * *} \\
(0.01)\end{array}$ & $\begin{array}{c}0.02^{* * *} \\
(0.01)\end{array}$ \\
\hline Very interested in politics & $\begin{array}{c}2.12^{* * *} \\
(0.17)\end{array}$ & $\begin{array}{l}1.48^{* * *} \\
(0.09)\end{array}$ & $\begin{array}{l}0.70^{*} \\
(0.32)\end{array}$ & $\begin{array}{c}2.14^{* * *} \\
(0.22)\end{array}$ & $\begin{array}{c}1.08^{* * *} \\
(0.23)\end{array}$ & $\begin{array}{c}1.33^{* * *} \\
(0.14)\end{array}$ & $\begin{array}{c}1.11^{* * *} \\
(0.12)\end{array}$ & $\begin{array}{c}1.53^{* * *} \\
(0.18)\end{array}$ & $\begin{array}{c}1.19^{* * *} \\
(0.10)\end{array}$ \\
\hline Quite interested in politics & $\begin{array}{c}1.21^{* * *} \\
(0.15)\end{array}$ & $\begin{array}{c}1.00^{* * *} \\
(0.08)\end{array}$ & $\begin{array}{c}0.38 \\
(0.29)\end{array}$ & $\begin{array}{c}1.24^{* * *} \\
(0.19)\end{array}$ & $\begin{array}{l}0.43^{*} \\
(0.21)\end{array}$ & $\begin{array}{c}1.06^{* * *} \\
(0.13)\end{array}$ & $\begin{array}{c}0.88^{* * *} \\
(0.11)\end{array}$ & $\begin{array}{c}0.73^{* * *} \\
(0.14)\end{array}$ & $\begin{array}{c}0.79^{* * *} \\
(0.09)\end{array}$ \\
\hline Hardly interested & $\begin{array}{c}0.53^{* * *} \\
(0.15)\end{array}$ & $\begin{array}{c}0.31^{* * *} \\
(0.08)\end{array}$ & $\begin{array}{c}0.07 \\
(0.30)\end{array}$ & $\begin{array}{c}0.70^{* * *} \\
(0.19)\end{array}$ & $\begin{array}{c}0.13 \\
(0.21)\end{array}$ & $\begin{array}{c}0.61^{* * *} \\
(0.13)\end{array}$ & $\begin{array}{c}0.52^{* * *} \\
(0.11)\end{array}$ & $\begin{array}{c}0.24 \\
(0.15)\end{array}$ & $\begin{array}{c}0.51^{* * *} \\
(0.09)\end{array}$ \\
\hline TU member & $\begin{array}{c}0.73^{* * *} \\
(0.13)\end{array}$ & $\begin{array}{c}0.36^{* * *} \\
(0.06)\end{array}$ & $\begin{array}{l}0.35^{*} \\
(0.15)\end{array}$ & $\begin{array}{c}0.73^{* * *} \\
(0.13)\end{array}$ & $\begin{array}{c}0.42^{* * *} \\
(0.13)\end{array}$ & $\begin{array}{c}0.36^{* * *} \\
(0.06)\end{array}$ & $\begin{array}{c}0.16^{* * *} \\
(0.04)\end{array}$ & $\begin{array}{c}0.76^{* * *} \\
(0.14)\end{array}$ & $\begin{array}{c}0.20^{* * *} \\
(0.04)\end{array}$ \\
\hline Democratic satisfaction & $\begin{array}{c}-0.07^{* * *} \\
(0.02)\end{array}$ & $\begin{array}{c}-0.02^{*} \\
(0.01)\end{array}$ & $\begin{array}{c}-0.06^{+} \\
(0.03)\end{array}$ & $\begin{array}{l}-0.03 \\
(0.02)\end{array}$ & $\begin{array}{c}0.01 \\
(0.03)\end{array}$ & $\begin{array}{l}-0.01 \\
(0.01)\end{array}$ & $\begin{array}{c}-0.02^{+} \\
(0.01)\end{array}$ & $\begin{array}{l}-0.02 \\
(0.02)\end{array}$ & $\begin{array}{c}-0.04^{* * *} \\
(0.01)\end{array}$ \\
\hline Ideological opponent of the incumbent cabinet & $\begin{array}{l}-0.12 \\
(0.12)\end{array}$ & $\begin{array}{c}0.00 \\
(.)\end{array}$ & $\begin{array}{c}0.16 \\
(0.16)\end{array}$ & $\begin{array}{l}-0.11 \\
(0.13)\end{array}$ & $\begin{array}{c}0.00 \\
(.)\end{array}$ & $\begin{array}{c}0.01 \\
(0.08)\end{array}$ & $\begin{array}{c}0.04 \\
(0.05)\end{array}$ & $\begin{array}{c}0.23^{*} \\
(0.11)\end{array}$ & $\begin{array}{c}0.06 \\
(0.04)\end{array}$ \\
\hline Constant & $\begin{array}{c}-3.31^{* * *} \\
(0.34)\end{array}$ & $\begin{array}{c}-1.46^{* * *} \\
(0.17)\end{array}$ & $\begin{array}{l}-0.02 \\
(0.48)\end{array}$ & $\begin{array}{c}-2.10^{* * *} \\
(0.32)\end{array}$ & $\begin{array}{c}-1.21^{* *} \\
(0.44)\end{array}$ & $\begin{array}{c}-3.17^{* * *} \\
(0.19)\end{array}$ & $\begin{array}{c}-0.88^{* * *} \\
(0.16)\end{array}$ & $\begin{array}{c}-3.68^{* * *} \\
(0.31)\end{array}$ & $\begin{array}{c}-1.00^{* * *} \\
(0.15)\end{array}$ \\
\hline ESS wave dummies & Yes & Yes & Yes & Yes & Yes & Yes & Yes & Yes & Yes \\
\hline Observations & 7107 & 11712 & 1058 & 2698 & 1893 & 12061 & 10267 & 8863 & 11088 \\
\hline Pseudo $R^{2}$ & 0.17 & 0.08 & 0.05 & 0.13 & 0.06 & 0.06 & 0.05 & 0.18 & 0.04 \\
\hline
\end{tabular}


Table EA5: Ideology and Protest Participation by Country (East)

\begin{tabular}{|c|c|c|c|c|c|c|c|c|c|}
\hline & \multicolumn{3}{|c|}{ Western Pattern } & \multicolumn{4}{|c|}{ Eastern Pattern } & \multicolumn{2}{|c|}{ Mixed Pattern } \\
\hline & $(1)$ & $(2)$ & $(3)$ & $(4)$ & $(5)$ & $(6)$ & $(7)$ & (8) & (9) \\
\hline & Estonia & Croatia & Slovenia & Bulgaria & Czech Republic & Hungary & Poland & Lithuania & Slovakia \\
\hline & b & b & $\mathrm{b}$ & $\mathrm{b}$ & $\mathrm{b}$ & $\mathrm{b}$ & b & b & b \\
\hline \multirow[t]{2}{*}{ Left-wing } & 0.14 & $0.41^{* *}$ & $0.20^{+}$ & $-0.33^{*}$ & $-0.12^{+}$ & $-0.72^{* * *}$ & -0.14 & 0.17 & -0.07 \\
\hline & $(0.10)$ & $(0.15)$ & $(0.10)$ & $(0.13)$ & $(0.08)$ & $(0.12)$ & $(0.10)$ & $(0.18)$ & $(0.08)$ \\
\hline \multirow[t]{2}{*}{ Center } & $-0.29^{* * *}$ & 0.07 & -0.07 & $-0.50^{* * *}$ & $-0.28^{* *}$ & $-0.88^{* * *}$ & $-0.28^{* * *}$ & 0.19 & $-0.18^{*}$ \\
\hline & $(0.09)$ & $(0.15)$ & $(0.12)$ & $(0.14)$ & $(0.09)$ & $(0.14)$ & $(0.08)$ & $(0.20)$ & $(0.09)$ \\
\hline \multirow[t]{2}{*}{ Female } & $0.30^{* * *}$ & -0.03 & $0.25^{* * *}$ & -0.10 & $0.12^{*}$ & -0.00 & 0.07 & $0.35^{*}$ & 0.01 \\
\hline & $(0.08)$ & $(0.12)$ & $(0.08)$ & $(0.10)$ & $(0.06)$ & $(0.09)$ & $(0.07)$ & $(0.15)$ & $(0.07)$ \\
\hline \multirow[t]{2}{*}{ Age } & $-0.02^{* * *}$ & $-0.01^{* *}$ & $-0.03^{* * *}$ & $-0.02^{* * *}$ & $-0.02^{* * *}$ & $-0.02^{* * *}$ & $-0.02^{* * *}$ & $-0.01^{* *}$ & $-0.02^{* * *}$ \\
\hline & $(0.00)$ & $(0.00)$ & $(0.00)$ & $(0.00)$ & $(0.00)$ & $(0.00)$ & $(0.00)$ & $(0.00)$ & $(0.00)$ \\
\hline \multirow[t]{2}{*}{ Education (in years) } & $0.12^{* * *}$ & $0.12^{* * *}$ & $0.09^{* * *}$ & $0.15^{* * *}$ & $0.10^{* * *}$ & $0.11^{* * *}$ & $0.15^{* * *}$ & $0.13^{* * *}$ & $0.06^{* * *}$ \\
\hline & $(0.01)$ & $(0.02)$ & $(0.01)$ & $(0.02)$ & $(0.01)$ & $(0.01)$ & $(0.01)$ & $(0.03)$ & $(0.01)$ \\
\hline \multirow[t]{2}{*}{ Very interested in politics } & $1.42^{* * *}$ & $1.59^{* * *}$ & $1.46^{* * *}$ & $1.34^{* * *}$ & $1.67^{* * *}$ & $2.36^{* * *}$ & $1.68^{* * *}$ & $0.95^{* *}$ & $1.28^{* * *}$ \\
\hline & $(0.22)$ & $(0.22)$ & $(0.19)$ & $(0.23)$ & $(0.15)$ & $(0.26)$ & $(0.18)$ & $(0.36)$ & $(0.17)$ \\
\hline \multirow[t]{2}{*}{ Quite interested in politics } & $1.22^{* * *}$ & $1.02^{* * *}$ & $1.15^{* * *}$ & $0.65^{* *}$ & $1.13^{* * *}$ & $1.90^{* * *}$ & $1.09^{* * *}$ & $0.63^{*}$ & $1.03^{* * *}$ \\
\hline & $(0.19)$ & $(0.17)$ & $(0.16)$ & $(0.20)$ & $(0.10)$ & $(0.24)$ & $(0.15)$ & $(0.25)$ & $(0.14)$ \\
\hline \multirow[t]{2}{*}{ Hardly interested } & $0.62^{* *}$ & $0.59^{* * *}$ & $0.54^{* * *}$ & $0.45^{*}$ & $0.65^{* * *}$ & $0.84^{* * *}$ & $0.44^{* *}$ & 0.21 & $0.51^{* * *}$ \\
\hline & $(0.19)$ & $(0.17)$ & $(0.16)$ & $(0.21)$ & $(0.09)$ & $(0.24)$ & $(0.15)$ & $(0.23)$ & $(0.14)$ \\
\hline \multirow[t]{2}{*}{ TU member } & $0.52^{* * *}$ & $0.27^{+}$ & $0.29^{* *}$ & $0.70^{* * *}$ & $0.35^{* * *}$ & $0.42^{* *}$ & $0.68^{* * *}$ & $0.56^{*}$ & $0.39^{* * *}$ \\
\hline & $(0.13)$ & $(0.16)$ & $(0.09)$ & $(0.16)$ & $(0.11)$ & $(0.15)$ & $(0.11)$ & $(0.27)$ & $(0.11)$ \\
\hline \multirow[t]{2}{*}{ Democratic satisfaction } & 0.03 & -0.00 & -0.03 & -0.02 & $-0.03^{+}$ & $-0.08^{* * *}$ & -0.02 & -0.01 & $-0.05^{* *}$ \\
\hline & $(0.02)$ & $(0.03)$ & $(0.02)$ & $(0.02)$ & $(0.01)$ & $(0.02)$ & $(0.02)$ & $(0.03)$ & $(0.02)$ \\
\hline \multirow[t]{2}{*}{ Ideological opponent of the incumbent cabinet } & 0.00 & 0.00 & 0.03 & $0.25^{*}$ & 0.03 & $0.20^{+}$ & -0.09 & 0.03 & 0.01 \\
\hline & $()$. & $()$. & $(0.10)$ & $(0.12)$ & $(0.07)$ & $(0.12)$ & $(0.10)$ & $(0.17)$ & $(0.08)$ \\
\hline \multirow[t]{2}{*}{ Constant } & $-4.60^{* * *}$ & $-2.85^{* * *}$ & $-2.51^{* * *}$ & $-4.03^{* * *}$ & $-2.66^{* * *}$ & $-4.04^{* * *}$ & $-4.23^{* * *}$ & $-3.25^{* * *}$ & $-1.51^{* * *}$ \\
\hline & $(0.30)$ & $(0.38)$ & $(0.28)$ & $(0.35)$ & $(0.24)$ & $(0.34)$ & $(0.25)$ & $(0.54)$ & $(0.24)$ \\
\hline ESS wave dummies & Yes & Yes & Yes & Yes & Yes & Yes & Yes & Yes & Yes \\
\hline Observations & 7588 & 2166 & 6525 & 5770 & 10138 & 8691 & 9182 & 3744 & 6970 \\
\hline Pseudo $R^{2}$ & 0.09 & 0.09 & 0.09 & 0.09 & 0.06 & 0.14 & 0.11 & 0.08 & 0.04 \\
\hline
\end{tabular}

Note: Logistic regressions. Robust standard errors in parentheses. Significance levels: ${ }^{+} p<0.1,{ }^{*} p<0.05,{ }^{* *} p<0.01,{ }^{* * *} p<0.001$. 
Table EA6: Replication of Table 2: Continuous L/R Scale

\begin{tabular}{|c|c|c|c|c|}
\hline & $\begin{array}{c}(1) \\
\text { West } \\
b\end{array}$ & $\begin{array}{c}(2) \\
\text { East: WP } \\
\text { b }\end{array}$ & $\begin{array}{c}(3) \\
\text { East: EP } \\
\text { b }\end{array}$ & $\begin{array}{c}(4) \\
\text { East: MP } \\
\text { b }\end{array}$ \\
\hline $\mathrm{L} / \mathrm{R}$ scale & $\begin{array}{c}-0.10^{* * *} \\
(0.00)\end{array}$ & $\begin{array}{c}-0.02^{*} \\
(0.01)\end{array}$ & $\begin{array}{c}0.06^{* * *} \\
(0.01)\end{array}$ & $\begin{array}{l}-0.00 \\
(0.01)\end{array}$ \\
\hline Center & $\begin{array}{c}-0.13^{* * *} \\
(0.02)\end{array}$ & $\begin{array}{c}-0.22^{* * *} \\
(0.06)\end{array}$ & $\begin{array}{c}-0.27^{* * *} \\
(0.05)\end{array}$ & $\begin{array}{l}-0.08 \\
(0.08)\end{array}$ \\
\hline Female & $\begin{array}{c}0.25^{* * *} \\
(0.01)\end{array}$ & $\begin{array}{c}0.21^{* * *} \\
(0.05)\end{array}$ & $\begin{array}{c}0.06 \\
(0.04)\end{array}$ & $\begin{array}{l}0.10^{+} \\
(0.06)\end{array}$ \\
\hline Age & $\begin{array}{c}-0.01^{* * *} \\
(0.00)\end{array}$ & $\begin{array}{c}-0.02^{* * *} \\
(0.00)\end{array}$ & $\begin{array}{c}-0.02^{* * *} \\
(0.00)\end{array}$ & $\begin{array}{c}-0.02^{* * *} \\
(0.00)\end{array}$ \\
\hline Education (in years) & $\begin{array}{c}0.07^{* * *} \\
(0.00)\end{array}$ & $\begin{array}{c}0.11^{* * *} \\
(0.01)\end{array}$ & $\begin{array}{c}0.13^{* * *} \\
(0.01)\end{array}$ & $\begin{array}{c}0.08^{* * *} \\
(0.01)\end{array}$ \\
\hline Very interested in politics & $\begin{array}{c}1.36^{* * *} \\
(0.03)\end{array}$ & $\begin{array}{c}1.46^{* * *} \\
(0.12)\end{array}$ & $\begin{array}{c}1.77^{* * * *} \\
(0.09)\end{array}$ & $\begin{array}{c}1.15^{* * *} \\
(0.16)\end{array}$ \\
\hline Quite interested in politics & $\begin{array}{c}0.98^{* * *} \\
(0.02)\end{array}$ & $\begin{array}{c}1.15^{* * *} \\
(0.10)\end{array}$ & $\begin{array}{c}1.18^{* * *} \\
(0.07)\end{array}$ & $\begin{array}{c}0.89^{* * *} \\
(0.12)\end{array}$ \\
\hline Hardly interested & $\begin{array}{c}0.52^{* * *} \\
(0.02)\end{array}$ & $\begin{array}{c}0.58^{* * *} \\
(0.10)\end{array}$ & $\begin{array}{c}0.60^{* * *} \\
(0.07)\end{array}$ & $\begin{array}{l}0.39^{* *} \\
(0.12)\end{array}$ \\
\hline TU member & $\begin{array}{c}0.32^{* * *} \\
(0.01)\end{array}$ & $\begin{array}{c}0.36^{* * *} \\
(0.07)\end{array}$ & $\begin{array}{c}0.52^{* * *} \\
(0.06)\end{array}$ & $\begin{array}{c}0.43^{* * *} \\
(0.10)\end{array}$ \\
\hline Democratic satisfaction & $\begin{array}{c}-0.03^{* * *} \\
(0.00)\end{array}$ & $\begin{array}{c}0.00 \\
(0.01)\end{array}$ & $\begin{array}{c}-0.04^{* * *} \\
(0.01)\end{array}$ & $\begin{array}{c}-0.04^{* *} \\
(0.01)\end{array}$ \\
\hline Ideol. opponent of the incumbent & $\begin{array}{c}0.11^{* * *} \\
(0.01)\end{array}$ & $\begin{array}{c}0.06 \\
(0.07)\end{array}$ & $\begin{array}{l}0.08^{+} \\
(0.05)\end{array}$ & $\begin{array}{c}0.01 \\
(0.08)\end{array}$ \\
\hline Constant & $\begin{array}{c}-1.53^{* * *} \\
(0.05)\end{array}$ & $\begin{array}{c}-3.27^{* * *} \\
(0.21)\end{array}$ & $\begin{array}{c}-4.26^{* * *} \\
(0.15)\end{array}$ & $\begin{array}{c}-2.34^{* * *} \\
(0.25)\end{array}$ \\
\hline ESS wave dummies & Yes & Yes & Yes & Yes \\
\hline Country dummies & Yes & Yes & Yes & Yes \\
\hline Observations & 163830 & 16279 & 33781 & 10714 \\
\hline Pseudo $R^{2}$ & 0.10 & 0.11 & 0.11 & 0.06 \\
\hline
\end{tabular}


Table EA7: Replication of Table 2: Demonstrations Only

\begin{tabular}{|c|c|c|c|c|}
\hline & $\begin{array}{c}(1) \\
\text { West } \\
b\end{array}$ & $\begin{array}{c}(2) \\
\text { East: WP } \\
\text { b }\end{array}$ & $\begin{array}{c}(3) \\
\text { East: EP } \\
\text { b }\end{array}$ & $\begin{array}{c}(4) \\
\text { East: MP } \\
\text { b }\end{array}$ \\
\hline Left-wing & $\begin{array}{c}0.94^{* * *} \\
(0.03)\end{array}$ & $\begin{array}{c}0.47^{* *} \\
(0.14)\end{array}$ & $\begin{array}{c}-0.31^{* * *} \\
(0.08)\end{array}$ & $\begin{array}{c}-0.16 \\
(0.18)\end{array}$ \\
\hline Center & $\begin{array}{c}0.24^{* * *} \\
(0.03)\end{array}$ & $\begin{array}{l}-0.11 \\
(0.11)\end{array}$ & $\begin{array}{c}-0.60^{* * *} \\
(0.09)\end{array}$ & $\begin{array}{l}-0.11 \\
(0.19)\end{array}$ \\
\hline Female & $\begin{array}{c}0.01 \\
(0.02)\end{array}$ & $\begin{array}{l}-0.10 \\
(0.09)\end{array}$ & $\begin{array}{c}-0.33^{* * *} \\
(0.07)\end{array}$ & $\begin{array}{l}-0.03 \\
(0.14)\end{array}$ \\
\hline Age & $\begin{array}{c}-0.02^{* * *} \\
(0.00)\end{array}$ & $\begin{array}{c}-0.02^{* * *} \\
(0.00)\end{array}$ & $\begin{array}{c}-0.02^{* * *} \\
(0.00)\end{array}$ & $\begin{array}{l}-0.00 \\
(0.00)\end{array}$ \\
\hline Education (in years) & $\begin{array}{c}0.05^{* * *} \\
(0.00)\end{array}$ & $\begin{array}{c}0.09^{* * *} \\
(0.01)\end{array}$ & $\begin{array}{c}0.09^{* * *} \\
(0.01)\end{array}$ & $\begin{array}{c}0.09^{* * *} \\
(0.02)\end{array}$ \\
\hline Very interested in politics & $\begin{array}{c}1.67^{* * *} \\
(0.05)\end{array}$ & $\begin{array}{c}1.71^{* * *} \\
(0.19)\end{array}$ & $\begin{array}{c}1.83^{* * *} \\
(0.14)\end{array}$ & $\begin{array}{l}0.77^{*} \\
(0.34)\end{array}$ \\
\hline Quite interested in politics & $\begin{array}{c}1.03^{* * *} \\
(0.05)\end{array}$ & $\begin{array}{c}1.03^{* * *} \\
(0.18)\end{array}$ & $\begin{array}{c}1.13^{* * *} \\
(0.12)\end{array}$ & $\begin{array}{l}0.77^{* *} \\
(0.29)\end{array}$ \\
\hline Hardly interested & $\begin{array}{c}0.43^{* * *} \\
(0.05)\end{array}$ & $\begin{array}{c}0.60^{* * *} \\
(0.18)\end{array}$ & $\begin{array}{c}0.45^{* * *} \\
(0.12)\end{array}$ & $\begin{array}{c}0.27 \\
(0.28)\end{array}$ \\
\hline TU member & $\begin{array}{c}0.56^{* * *} \\
(0.03)\end{array}$ & $\begin{array}{c}0.66^{* * *} \\
(0.11)\end{array}$ & $\begin{array}{c}0.72^{* * *} \\
(0.10)\end{array}$ & $\begin{array}{c}0.28 \\
(0.22)\end{array}$ \\
\hline Democratic satisfaction & $\begin{array}{c}-0.05^{* * *} \\
(0.00)\end{array}$ & $\begin{array}{l}-0.02 \\
(0.02)\end{array}$ & $\begin{array}{c}-0.05^{* *} \\
(0.02)\end{array}$ & $\begin{array}{c}-0.05^{+} \\
(0.03)\end{array}$ \\
\hline Ideol. opponent of the incumbent & $\begin{array}{c}0.09^{* * *} \\
(0.02)\end{array}$ & $\begin{array}{l}-0.18 \\
(0.14)\end{array}$ & $\begin{array}{l}0.14^{+} \\
(0.08)\end{array}$ & $\begin{array}{l}-0.10 \\
(0.18)\end{array}$ \\
\hline Constant & $\begin{array}{c}-3.72^{* * *} \\
(0.09)\end{array}$ & $\begin{array}{c}-4.78^{* * *} \\
(0.37)\end{array}$ & $\begin{array}{c}-3.77^{* * *} \\
(0.24)\end{array}$ & $\begin{array}{c}-4.31^{* * *} \\
(0.56)\end{array}$ \\
\hline ESS wave dummies & Yes & Yes & Yes & Yes \\
\hline Country dummies & Yes & Yes & Yes & Yes \\
\hline Observations & 163736 & 16256 & 33731 & 10701 \\
\hline Pseudo $R^{2}$ & 0.14 & 0.10 & 0.09 & 0.03 \\
\hline
\end{tabular}


Table EA8: Replication of Table 2: Petitions Only

\begin{tabular}{lcccc}
\hline \hline & $(1)$ & $(2)$ & $(3)$ & $(4)$ \\
& West & East: WP & East: EP & East: MP \\
& $\mathrm{b}$ & $\mathrm{b}$ & $\mathrm{b}$ & $\mathrm{b}$ \\
\hline Left-wing & $0.39^{* * *}$ & 0.11 & $-0.25^{* * *}$ & -0.03 \\
Center & $(0.02)$ & $(0.08)$ & $(0.05)$ & $(0.08)$ \\
& $0.08^{* * *}$ & $-0.18^{* *}$ & $-0.36^{* * *}$ & -0.09 \\
Female & $(0.02)$ & $(0.07)$ & $(0.05)$ & $(0.08)$ \\
& $0.28^{* * *}$ & $0.26^{* * *}$ & $0.11^{* *}$ & $0.12^{+}$ \\
Age & $(0.01)$ & $(0.05)$ & $(0.04)$ & $(0.06)$ \\
& $-0.01^{* * *}$ & $-0.02^{* * *}$ & $-0.02^{* * *}$ & $-0.02^{* * *}$ \\
Education (in years) & $(0.00)$ & $(0.00)$ & $(0.00)$ & $(0.00)$ \\
& $0.07^{* * *}$ & $0.12^{* * *}$ & $0.13^{* * *}$ & $0.08^{* * *}$ \\
Very interested in politics & $(0.00)$ & $(0.01)$ & $(0.01)$ & $(0.01)$ \\
& $1.30^{* * *}$ & $1.45^{* * *}$ & $1.76^{* * *}$ & $1.16^{* * *}$ \\
Quite interested in politics & $(0.03)$ & $(0.12)$ & $(0.09)$ & $(0.16)$ \\
& $0.95^{* * *}$ & $1.15^{* * *}$ & $1.18^{* * *}$ & $0.87^{* * *}$ \\
Hardly interested & $(0.03)$ & $(0.10)$ & $(0.08)$ & $(0.13)$ \\
TU member & $0.51^{* * *}$ & $0.57^{* * *}$ & $0.63^{* * *}$ & $0.39^{* *}$ \\
Democratic satisfaction & $(0.03)$ & $(0.10)$ & $(0.07)$ & $(0.12)$ \\
& $0.30^{* * *}$ & $0.28^{* * *}$ & $0.47^{* * *}$ & $0.45^{* * *}$ \\
Ideol. opponent of the incumbent & $(0.01)$ & $(0.07)$ & $(0.07)$ & $(0.11)$ \\
Constant & $-0.03^{* * *}$ & 0.01 & $-0.03^{* * *}$ & $-0.04^{*}$ \\
ESS wave dummies & $(0.00)$ & $(0.01)$ & $(0.01)$ & $(0.01)$ \\
Country dummies & $(0.01)$ & $(0.08)$ & $(0.05)$ & $(0.08)$ \\
Pbservations $R^{2}$ & $-2.38^{* * *}$ & $-3.67^{* * *}$ & $-4.22^{* * *}$ & $-2.42^{* * *}$ \\
\hline \hline & $(0.05)$ & $(0.21)$ & $(0.16)$ & $(0.25)$ \\
& Yes & Yes & Yes & Yes \\
& Yes & Yes & Yes & Yes \\
\hline Logdo & 163342 & 16249 & 33726 & 10669 \\
& 0.11 & 0.11 & 0.11 & 0.07 \\
\hline
\end{tabular}

Note: Logistic regressions. $\quad$ Robust standard errors in parentheses. Significance levels:

${ }^{+} p<0.1,{ }^{*} p<0.05,{ }^{* *} p<0.01,{ }^{* * *} p<0.001$. 
Table EA9: Replication of Table 2: Cumulative Scale (DV = Petitions + Demonstrations)

\begin{tabular}{|c|c|c|c|c|}
\hline & $\begin{array}{c}(1) \\
\text { West } \\
\mathrm{b}\end{array}$ & $\begin{array}{c}(2) \\
\text { East: WP } \\
\text { b }\end{array}$ & $\begin{array}{c}(3) \\
\text { East: EP } \\
\text { b }\end{array}$ & $\begin{array}{c}(4) \\
\text { M4 } \\
\mathrm{b}\end{array}$ \\
\hline Left-wing & $\begin{array}{c}0.45^{* * *} \\
(0.04)\end{array}$ & $\begin{array}{l}0.14^{* *} \\
(0.05)\end{array}$ & $\begin{array}{c}-0.27^{*} \\
(0.13)\end{array}$ & $\begin{array}{l}-0.03 \\
(0.08)\end{array}$ \\
\hline Center & $\begin{array}{c}0.09^{* * *} \\
(0.02)\end{array}$ & $\begin{array}{l}-0.16 \\
(0.10)\end{array}$ & $\begin{array}{c}-0.42^{* *} \\
(0.13)\end{array}$ & $\begin{array}{l}-0.10 \\
(0.12)\end{array}$ \\
\hline Female & $\begin{array}{c}0.25^{* * *} \\
(0.03)\end{array}$ & $\begin{array}{l}0.21^{*} \\
(0.09)\end{array}$ & $\begin{array}{c}0.05 \\
(0.04)\end{array}$ & $\begin{array}{c}0.10 \\
(0.13)\end{array}$ \\
\hline Age & $\begin{array}{c}-0.01^{* * *} \\
(0.00)\end{array}$ & $\begin{array}{c}-0.02^{* * *} \\
(0.01)\end{array}$ & $\begin{array}{c}-0.02^{* * *} \\
(0.00)\end{array}$ & $\begin{array}{c}-0.02^{* * *} \\
(0.00)\end{array}$ \\
\hline Education (in years) & $\begin{array}{c}0.07^{* * *} \\
(0.01)\end{array}$ & $\begin{array}{c}0.11^{* * *} \\
(0.01)\end{array}$ & $\begin{array}{c}0.13^{* * *} \\
(0.02)\end{array}$ & $\begin{array}{l}0.08^{* *} \\
(0.03)\end{array}$ \\
\hline Very interested in politics & $\begin{array}{c}1.36^{* * *} \\
(0.05)\end{array}$ & $\begin{array}{c}1.47^{* * *} \\
(0.06)\end{array}$ & $\begin{array}{c}1.79^{* * *} \\
(0.15)\end{array}$ & $\begin{array}{c}1.18^{* * *} \\
(0.14)\end{array}$ \\
\hline Quite interested in politics & $\begin{array}{c}0.98^{* * *} \\
(0.04)\end{array}$ & $\begin{array}{c}1.15^{* * *} \\
(0.02)\end{array}$ & $\begin{array}{c}1.19^{* * *} \\
(0.18)\end{array}$ & $\begin{array}{c}0.91^{* * *} \\
(0.16)\end{array}$ \\
\hline Hardly interested in politics & $\begin{array}{c}0.51^{* * *} \\
(0.04)\end{array}$ & $\begin{array}{c}0.58^{* * *} \\
(0.03)\end{array}$ & $\begin{array}{c}0.62^{* * *} \\
(0.06)\end{array}$ & $\begin{array}{l}0.41^{* *} \\
(0.13)\end{array}$ \\
\hline TU member & $\begin{array}{c}0.33^{* * *} \\
(0.05)\end{array}$ & $\begin{array}{c}0.36^{* * *} \\
(0.07)\end{array}$ & $\begin{array}{c}0.53^{* * *} \\
(0.10)\end{array}$ & $\begin{array}{c}0.42^{* * *} \\
(0.04)\end{array}$ \\
\hline Democratic satisfaction & $\begin{array}{c}-0.03^{* * *} \\
(0.00)\end{array}$ & $\begin{array}{c}0.00 \\
(0.02)\end{array}$ & $\begin{array}{c}-0.04^{* *} \\
(0.01)\end{array}$ & $\begin{array}{l}-0.04^{*} \\
(0.01)\end{array}$ \\
\hline Ideol. opponent of the incumbent & $\begin{array}{c}0.10^{* * *} \\
(0.02)\end{array}$ & $\begin{array}{c}0.04 \\
(0.04)\end{array}$ & $\begin{array}{c}0.08 \\
(0.06)\end{array}$ & $\begin{array}{l}0.02^{+} \\
(0.01)\end{array}$ \\
\hline Constant & $\begin{array}{c}-2.22^{* * *} \\
(0.16)\end{array}$ & $\begin{array}{c}-3.45^{* * *} \\
(0.48)\end{array}$ & $\begin{array}{c}-3.83^{* * *} \\
(0.20)\end{array}$ & $\begin{array}{c}-2.33^{* * *} \\
(0.43)\end{array}$ \\
\hline ESS wave dummies & Yes & Yes & Yes & Yes \\
\hline Country dummies & Yes & Yes & Yes & Yes \\
\hline Observations & 163248 & 16226 & 33676 & 10656 \\
\hline Pseudo $R^{2}$ & 0.10 & 0.11 & 0.10 & 0.06 \\
\hline
\end{tabular}

Note: Logistic regressions. Robust standard errors in parentheses. Significance levels: $+p<0.1,{ }^{*} p<0.05,{ }^{* *} p<0.01,{ }^{* * *} p<0.001$. 
Table EA10: Replication of Table 2: Ideological Extremes

\begin{tabular}{|c|c|c|c|c|}
\hline & $\begin{array}{c}(1) \\
\text { West } \\
b\end{array}$ & $\begin{array}{c}(2) \\
\text { East: WP } \\
b\end{array}$ & $\begin{array}{c}(3) \\
\text { East: EP } \\
b\end{array}$ & $\begin{array}{c}(4) \\
\text { East: MP } \\
\text { b }\end{array}$ \\
\hline Left-wing & $\begin{array}{c}0.43^{* * *} \\
(0.02)\end{array}$ & $\begin{array}{l}0.13^{+} \\
(0.08)\end{array}$ & $\begin{array}{c}-0.22^{* * *} \\
(0.05)\end{array}$ & $\begin{array}{c}-0.06 \\
(0.08)\end{array}$ \\
\hline Left-wing extremist & $\begin{array}{c}0.23^{* * *} \\
(0.04)\end{array}$ & $\begin{array}{c}0.01 \\
(0.11)\end{array}$ & $\begin{array}{c}0.03 \\
(0.11)\end{array}$ & $\begin{array}{c}0.55^{* * *} \\
(0.14)\end{array}$ \\
\hline Center & $\begin{array}{c}0.08^{* * *} \\
(0.02)\end{array}$ & $\begin{array}{c}-0.17^{* *} \\
(0.06)\end{array}$ & $\begin{array}{c}-0.37^{* * *} \\
(0.05)\end{array}$ & $\begin{array}{l}-0.07 \\
(0.09)\end{array}$ \\
\hline Right-wing extremist & $\begin{array}{l}-0.03 \\
(0.04)\end{array}$ & $\begin{array}{l}-0.12 \\
(0.13)\end{array}$ & $\begin{array}{c}0.28^{* * *} \\
(0.07)\end{array}$ & $\begin{array}{c}0.18 \\
(0.15)\end{array}$ \\
\hline Female & $\begin{array}{c}0.25^{* * *} \\
(0.01)\end{array}$ & $\begin{array}{c}0.21^{* * *} \\
(0.05)\end{array}$ & $\begin{array}{c}0.06 \\
(0.04)\end{array}$ & $\begin{array}{l}0.11^{+} \\
(0.06)\end{array}$ \\
\hline Age & $\begin{array}{c}-0.01^{* * *} \\
(0.00)\end{array}$ & $\begin{array}{c}-0.02^{* * *} \\
(0.00)\end{array}$ & $\begin{array}{c}-0.02^{* * *} \\
(0.00)\end{array}$ & $\begin{array}{c}-0.02^{* * *} \\
(0.00)\end{array}$ \\
\hline Education (in years) & $\begin{array}{c}0.07^{* * *} \\
(0.00)\end{array}$ & $\begin{array}{c}0.11^{* * *} \\
(0.01)\end{array}$ & $\begin{array}{c}0.13^{* * *} \\
(0.01)\end{array}$ & $\begin{array}{c}0.08^{* * *} \\
(0.01)\end{array}$ \\
\hline Very interested in politics & $\begin{array}{c}1.35^{* * *} \\
(0.03)\end{array}$ & $\begin{array}{c}1.47^{* * *} \\
(0.12)\end{array}$ & $\begin{array}{c}1.75^{* * *} \\
(0.09)\end{array}$ & $\begin{array}{c}1.11^{* * *} \\
(0.16)\end{array}$ \\
\hline Quite interested in politics & $\begin{array}{c}0.98^{* * *} \\
(0.02)\end{array}$ & $\begin{array}{c}1.15^{* * *} \\
(0.10)\end{array}$ & $\begin{array}{c}1.18^{* * *} \\
(0.07)\end{array}$ & $\begin{array}{c}0.90^{* * *} \\
(0.12)\end{array}$ \\
\hline Hardly interested & $\begin{array}{c}0.52^{* * *} \\
(0.02)\end{array}$ & $\begin{array}{c}0.58^{* * *} \\
(0.10)\end{array}$ & $\begin{array}{c}0.61^{* * *} \\
(0.07)\end{array}$ & $\begin{array}{c}0.40^{* * *} \\
(0.12)\end{array}$ \\
\hline TU member & $\begin{array}{c}0.32^{* * *} \\
(0.01)\end{array}$ & $\begin{array}{c}0.36^{* * *} \\
(0.07)\end{array}$ & $\begin{array}{c}0.52^{* * *} \\
(0.06)\end{array}$ & $\begin{array}{c}0.43^{* * *} \\
(0.10)\end{array}$ \\
\hline Democratic satisfaction & $\begin{array}{c}-0.03^{* * *} \\
(0.00)\end{array}$ & $\begin{array}{c}0.00 \\
(0.01)\end{array}$ & $\begin{array}{c}-0.04^{* * *} \\
(0.01)\end{array}$ & $\begin{array}{l}-0.03^{*} \\
(0.01)\end{array}$ \\
\hline Ideol. opponent of the incumbent & $\begin{array}{c}0.10^{* * *} \\
(0.01)\end{array}$ & $\begin{array}{c}0.04 \\
(0.07)\end{array}$ & $\begin{array}{l}0.08^{+} \\
(0.05)\end{array}$ & $\begin{array}{c}0.01 \\
(0.08)\end{array}$ \\
\hline Constant & $\begin{array}{c}-2.22^{* * *} \\
(0.05)\end{array}$ & $\begin{array}{c}-3.45^{* * *} \\
(0.20)\end{array}$ & $\begin{array}{c}-3.88^{* * *} \\
(0.15)\end{array}$ & $\begin{array}{c}-2.37^{* * *} \\
(0.25)\end{array}$ \\
\hline ESS wave dummies & Yes & Yes & Yes & Yes \\
\hline Country dummies & Yes & Yes & Yes & Yes \\
\hline Observations & 163830 & 16279 & 33781 & 10714 \\
\hline Pseudo $R^{2}$ & 0.10 & 0.11 & 0.11 & 0.06 \\
\hline
\end{tabular}


Table EA11: Replication of Table 2: Clustered Standard Errors

\begin{tabular}{|c|c|c|c|c|}
\hline & \multirow{3}{*}{$\begin{array}{c}(1) \\
\text { West } \\
b\end{array}$} & (2) & (3) & \multirow{3}{*}{$\begin{array}{c}(4) \\
\text { East: MP } \\
\text { b }\end{array}$} \\
\hline & & East: WP & East: EP & \\
\hline & & b & b & \\
\hline \multirow[t]{2}{*}{ Left-wing } & $0.45^{* * *}$ & $0.15^{* *}$ & $-0.27^{*}$ & -0.03 \\
\hline & $(0.04)$ & $(0.05)$ & $(0.13)$ & $(0.07)$ \\
\hline \multirow[t]{2}{*}{ Center } & $0.09^{* * *}$ & -0.15 & $-0.42^{* * *}$ & -0.09 \\
\hline & $(0.02)$ & $(0.11)$ & $(0.13)$ & $(0.13)$ \\
\hline \multirow[t]{2}{*}{ Female } & $0.25^{* * *}$ & $0.21^{*}$ & 0.06 & 0.10 \\
\hline & $(0.04)$ & $(0.09)$ & $(0.04)$ & $(0.13)$ \\
\hline \multirow[t]{2}{*}{ Age } & $-0.01^{* * *}$ & $-0.02^{* * *}$ & $-0.02^{* * *}$ & $-0.02^{* * *}$ \\
\hline & $(0.00)$ & $(0.01)$ & $(0.00)$ & $(0.00)$ \\
\hline \multirow[t]{2}{*}{ Education (in years) } & $0.07^{* * *}$ & $0.11^{* * *}$ & $0.13^{* * *}$ & $0.08^{* *}$ \\
\hline & $(0.01)$ & $(0.01)$ & $(0.02)$ & $(0.03)$ \\
\hline \multirow[t]{2}{*}{ Very interested in politics } & $1.36^{* * *}$ & $1.46^{* * *}$ & $1.78^{* * *}$ & $1.15^{* * *}$ \\
\hline & $(0.05)$ & $(0.06)$ & $(0.15)$ & $(0.16)$ \\
\hline \multirow[t]{2}{*}{ Quite interested in politics } & $0.98^{* * *}$ & $1.15^{* * *}$ & $1.19^{* * *}$ & $0.89^{* * *}$ \\
\hline & $(0.04)$ & $(0.02)$ & $(0.17)$ & $(0.18)$ \\
\hline \multirow[t]{2}{*}{ Hardly interested } & $0.51^{* * *}$ & $0.58^{* * *}$ & $0.61^{* * *}$ & $0.39^{*}$ \\
\hline & $(0.04)$ & $(0.03)$ & $(0.06)$ & $(0.15)$ \\
\hline \multirow[t]{2}{*}{ TU member } & $0.32^{* * *}$ & $0.36^{* * *}$ & $0.52^{* * *}$ & $0.43^{* * *}$ \\
\hline & $(0.05)$ & $(0.07)$ & $(0.10)$ & $(0.07)$ \\
\hline \multirow[t]{2}{*}{ Democratic satisfaction } & $-0.03^{* * *}$ & 0.00 & $-0.04^{* *}$ & $-0.04^{* *}$ \\
\hline & $(0.00)$ & $(0.02)$ & $(0.01)$ & $(0.01)$ \\
\hline \multirow[t]{2}{*}{ Ideol. opponent of the incumbent } & $0.10^{* * *}$ & 0.04 & 0.08 & $0.02^{+}$ \\
\hline & $(0.02)$ & $(0.04)$ & $(0.06)$ & $(0.01)$ \\
\hline \multirow[t]{2}{*}{ Constant } & $-2.21^{* * *}$ & $-3.46^{* * *}$ & $-3.83^{* * *}$ & $-2.32^{* * *}$ \\
\hline & $(0.16)$ & $(0.47)$ & $(0.20)$ & $(0.42)$ \\
\hline ESS wave dummies & Yes & Yes & Yes & Yes \\
\hline Country dummies & Yes & Yes & Yes & Yes \\
\hline Observations & 163830 & 16279 & 33781 & 10714 \\
\hline Pseudo $R^{2}$ & 0.10 & 0.11 & 0.10 & 0.06 \\
\hline
\end{tabular}

Note: Logistic regressions. Clustered standard errors in parentheses. Significance levels:

${ }^{+} p<0.1,{ }^{*} p<0.05,{ }^{* *} p<0.01,{ }^{* * *} p<0.001$. 
Table EA12: Replication of Table 3: Continuous L/R scale, reduction of inc. inequalities

\begin{tabular}{|c|c|c|c|c|c|c|}
\hline & \multicolumn{2}{|c|}{ West } & \multirow{2}{*}{$\begin{array}{c}\text { East: V } \\
(3)\end{array}$} & \multirow{3}{*}{$\begin{array}{c}\text { Western Pattern } \\
(4) \\
\text { b }\end{array}$} & \multirow{3}{*}{$\begin{array}{c}\text { East: } \mathrm{E} \\
\quad(5) \\
\text { b }\end{array}$} & \multirow{3}{*}{$\begin{array}{c}\text { Eastern Pattern } \\
(6) \\
\mathrm{b}\end{array}$} \\
\hline & $(1)$ & $(2)$ & & & & \\
\hline & $\mathrm{b}$ & $\mathrm{b}$ & b & & & \\
\hline \multirow[t]{2}{*}{$\mathrm{L} / \mathrm{R}$ scale } & $0.11^{* * *}$ & & $0.12^{* * *}$ & & $0.12^{* * *}$ & \\
\hline & $(0.01)$ & & $(0.04)$ & & $(0.03)$ & \\
\hline \multirow[t]{2}{*}{$\mathrm{L} / \mathrm{R}$ scale $\times$ Cultural liberalism } & $-0.29^{* * *}$ & & $-0.23^{* * *}$ & & $-0.10^{*}$ & \\
\hline & $(0.02)$ & & $(0.06)$ & & $(0.04)$ & \\
\hline \multirow[t]{2}{*}{ Reduce inequality } & & $0.47^{* * *}$ & & 0.55 & & -0.09 \\
\hline & & $(0.11)$ & & $(0.47)$ & & $(0.26)$ \\
\hline \multirow{2}{*}{ Reduce inequality $\times$ Cultural liberalism } & & $-1.44^{* * *}$ & & -1.11 & & 0.53 \\
\hline & & $(0.17)$ & & $(0.75)$ & & $(0.43)$ \\
\hline \multirow[t]{2}{*}{ Cultural liberalism } & $3.01^{* * *}$ & $2.25^{* * *}$ & $2.35^{* * *}$ & $1.52^{* * *}$ & $1.10^{* * *}$ & $0.32^{+}$ \\
\hline & $(0.11)$ & $(0.07)$ & $(0.35)$ & $(0.27)$ & $(0.29)$ & $(0.18)$ \\
\hline \multirow[t]{2}{*}{ Female } & $0.21^{* * *}$ & $0.21^{* * *}$ & $0.18^{* *}$ & $0.17^{* *}$ & 0.07 & 0.07 \\
\hline & $(0.01)$ & $(0.01)$ & $(0.06)$ & $(0.06)$ & $(0.04)$ & $(0.04)$ \\
\hline \multirow[t]{2}{*}{ Age } & $-0.01^{* * *}$ & $-0.01^{* * *}$ & $-0.02^{* * *}$ & $-0.02^{* * *}$ & $-0.02^{* * *}$ & $-0.02^{* * *}$ \\
\hline & $(0.00)$ & $(0.00)$ & $(0.00)$ & $(0.00)$ & $(0.00)$ & $(0.00)$ \\
\hline \multirow[t]{2}{*}{ Education (in years) } & $0.05^{* * *}$ & $0.05^{* * *}$ & $0.10^{* * *}$ & $0.10^{* * *}$ & $0.11^{* * *}$ & $0.11^{* * *}$ \\
\hline & $(0.00)$ & $(0.00)$ & $(0.01)$ & $(0.01)$ & $(0.01)$ & $(0.01)$ \\
\hline \multirow[t]{2}{*}{ Very interested in politics } & $1.25^{* * *}$ & $1.27^{* * *}$ & $1.55^{* * *}$ & $1.57^{* * *}$ & $1.78^{* * *}$ & $1.79^{* * * *}$ \\
\hline & $(0.04)$ & $(0.04)$ & $(0.16)$ & $(0.16)$ & $(0.10)$ & $(0.10)$ \\
\hline \multirow[t]{2}{*}{ Quite interested in politics } & $0.94^{* * *}$ & $0.93^{* * *}$ & $1.28^{* * *}$ & $1.29^{* * *}$ & $1.22^{* * *}$ & $1.22^{* * *}$ \\
\hline & $(0.03)$ & $(0.03)$ & $(0.14)$ & $(0.14)$ & $(0.09)$ & $(0.09)$ \\
\hline \multirow[t]{2}{*}{ Hardly interested in politics } & $0.53^{* * *}$ & $0.51^{* * *}$ & $0.76^{* * *}$ & $0.77^{* * *}$ & $0.68^{* * *}$ & $0.68^{* * *}$ \\
\hline & $(0.03)$ & $(0.03)$ & $(0.14)$ & $(0.14)$ & $(0.08)$ & $(0.08)$ \\
\hline \multirow[t]{2}{*}{ TU member } & $0.32^{* * *}$ & $0.33^{* * *}$ & $0.33^{* * *}$ & $0.32^{* * *}$ & $0.52^{* * *}$ & $0.51^{* * *}$ \\
\hline & $(0.02)$ & $(0.02)$ & $(0.09)$ & $(0.09)$ & $(0.07)$ & $(0.07)$ \\
\hline \multirow[t]{2}{*}{ Democratic satisfaction } & $-0.05^{* * *}$ & $-0.05^{* * *}$ & -0.01 & -0.01 & $-0.04^{* * *}$ & $-0.04^{* * *}$ \\
\hline & $(0.00)$ & $(0.00)$ & $(0.01)$ & $(0.01)$ & $(0.01)$ & $(0.01)$ \\
\hline \multirow[t]{2}{*}{ Ideol. opponent of the incumbent } & $0.09^{* * *}$ & $0.14^{* * *}$ & 0.09 & 0.10 & 0.07 & 0.05 \\
\hline & $(0.01)$ & $(0.01)$ & $(0.07)$ & $(0.06)$ & $(0.05)$ & $(0.04)$ \\
\hline \multirow[t]{2}{*}{ Constant } & $-3.27^{* * *}$ & $-2.92^{* * *}$ & $-4.65^{* * *}$ & $-4.25^{* * *}$ & $-4.71^{* * *}$ & $-3.96^{* * *}$ \\
\hline & $(0.09)$ & $(0.08)$ & $(0.33)$ & $(0.29)$ & $(0.24)$ & $(0.19)$ \\
\hline ESS wave dummies & Yes & Yes & Yes & Yes & Yes & Yes \\
\hline Country dummies & Yes & Yes & Yes & Yes & Yes & Yes \\
\hline Observations & 110944 & 110089 & 9563 & 9475 & 23005 & 22748 \\
\hline Pseudo $R^{2}$ & 0.12 & 0.11 & 0.11 & 0.11 & 0.10 & 0.10 \\
\hline
\end{tabular}

Note: Logistic regressions. Robust standard errors in parentheses. Significance levels: ${ }^{+} p<0.1,{ }^{*} p<0.05,{ }^{* *} p<0.01,{ }^{* * *} p<0.001$. For a visual presentation of the results see Figures EA2 \& EA3. 
Figure EA1: Replication of Figure 4 (Continuous L/R scale)
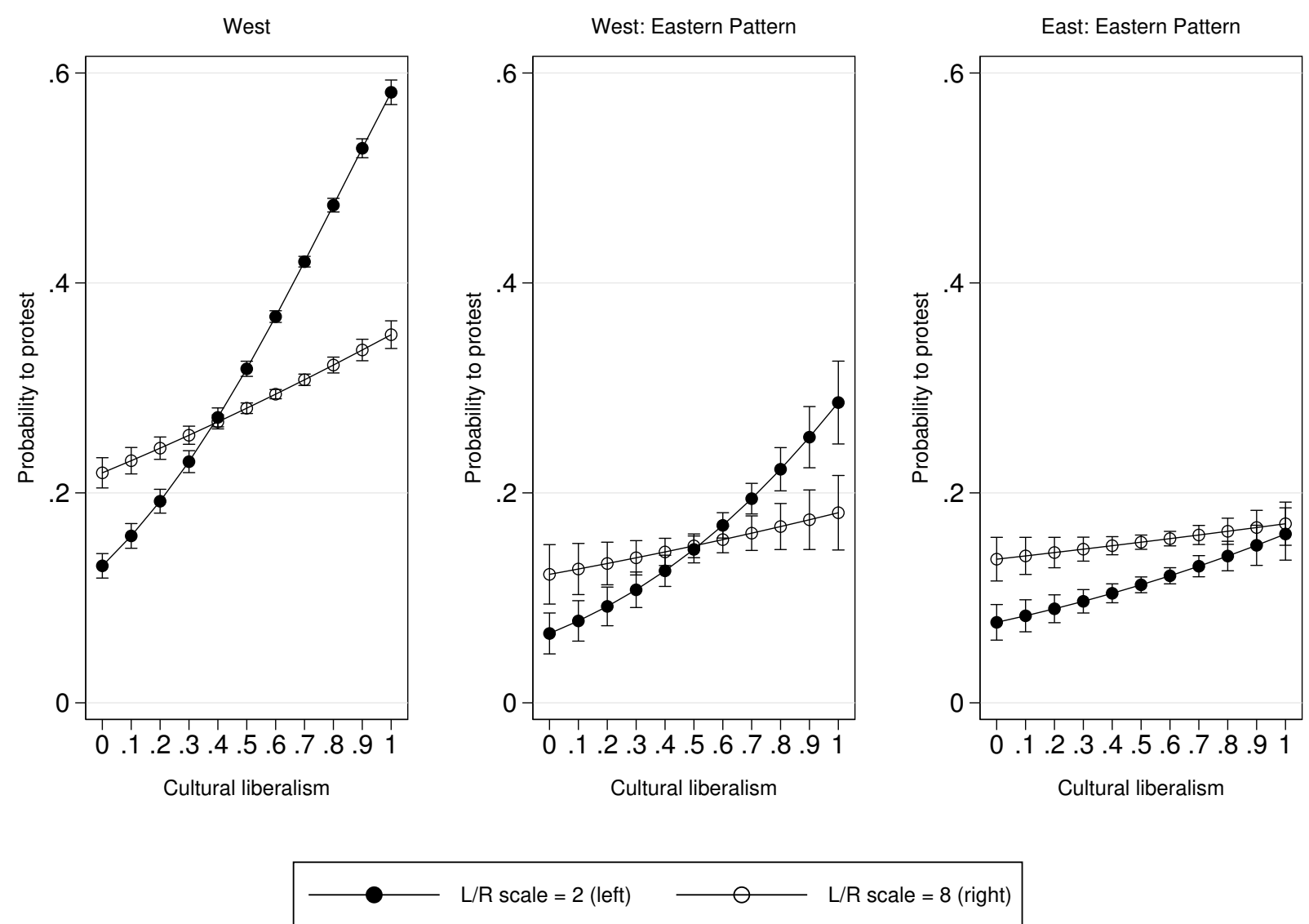

Note: Replication of Figure 4 using the continuous version of L/R scale. Based on Table EA6. $95 \%$ confidence intervals. 
Figure EA2: Replication of Figure 4 (Support for reduction of income inequalities)
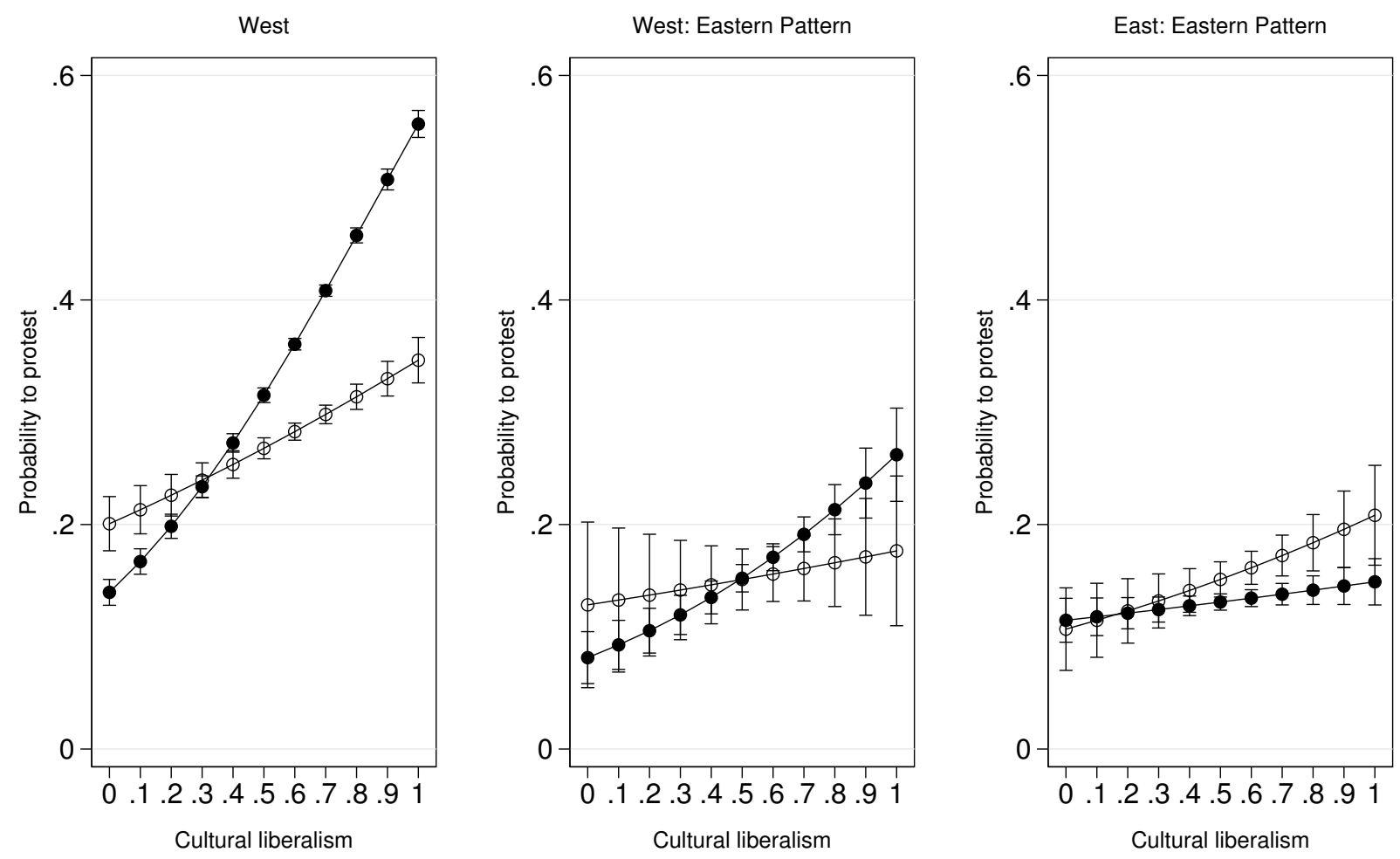

$\longrightarrow$ Reduce ineq. $=1$ (left) $\longrightarrow$ Reduce ineq. $=0$ (right)

Note: Replication of Figure 4 using support for reduction of income inequalities instead of the left/right categories. Based on Table EA12. $95 \%$ confidence intervals. 
Figure EA3: Replication of Figure 4 (EP pattern without Hungary)

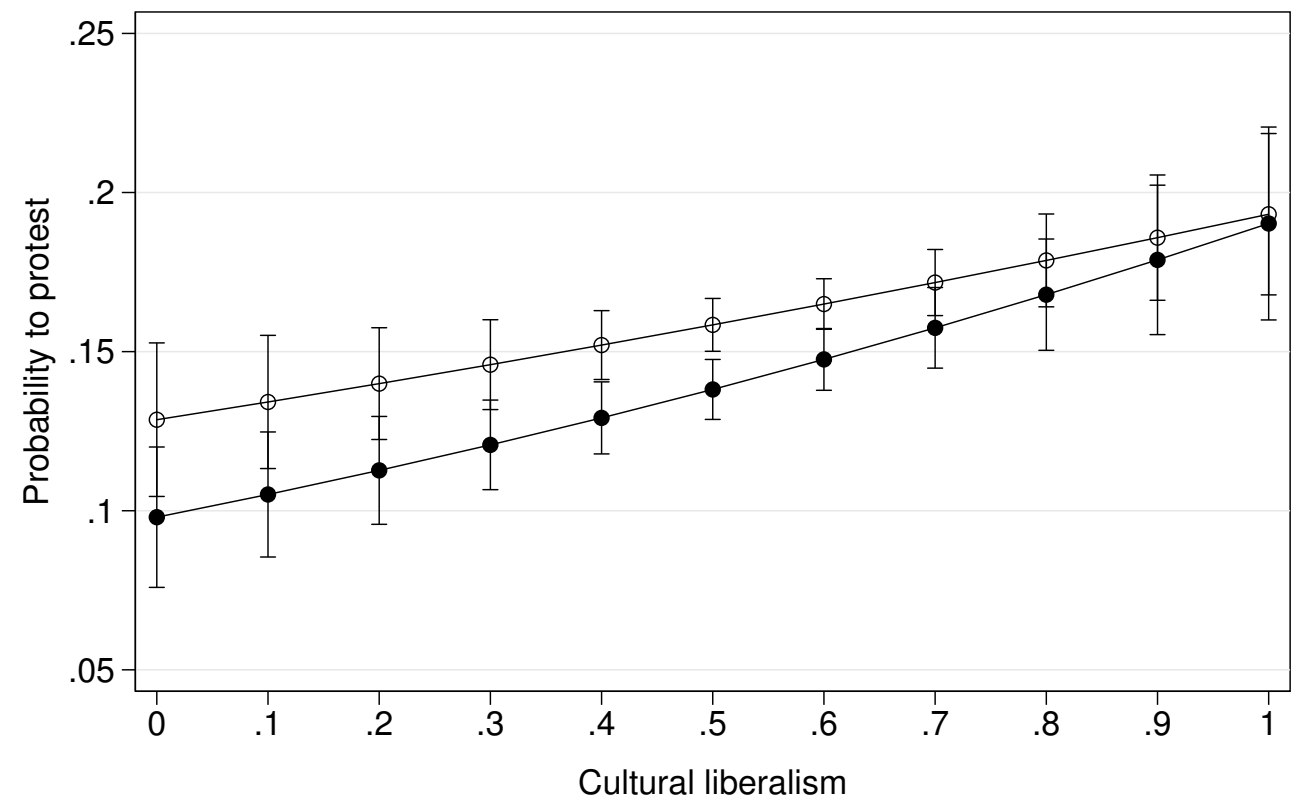

$\longrightarrow$ Right-wing $\longrightarrow$ Left-wing

Note: Replication of Figure 4 (East: EP) without Hungary. $95 \%$ confidence intervals. 
Table EA13: Scalability coefficient $H$ by country (ESS and EVS Data)

\begin{tabular}{lcc}
\hline Country & ESS & EVS \\
\hline Austria & 0.56 & 0.73 \\
Belgium & 0.56 & 0.70 \\
Bulgaria & 0.58 & 0.40 \\
Croatia & 0.80 & 0.79 \\
Czech Rep. & 0.67 & 0.65 \\
Denmark & 0.57 & 0.56 \\
Estonia & 0.40 & 0.41 \\
Spain & 0.50 & 0.46 \\
Finland & 0.72 & 0.71 \\
France & 0.60 & 0.69 \\
Germany & 0.58 & 0.69 \\
Great Britain & 0.78 & 0.85 \\
Greece & 0.47 & $\mathrm{NA}$ \\
Hungary & 0.47 & 0.72 \\
Ireland & 0.64 & 0.75 \\
Iceland & 0.59 & 0.68 \\
Italy & 0.51 & $\mathrm{NA}$ \\
Latvia & $\mathrm{NA}$ & 0.40 \\
Lithuania & 0.49 & 0.56 \\
Luxembourg & 0.45 & $\mathrm{NA}$ \\
Netherlands & 0.59 & 0.72 \\
Norway & 0.60 & $\mathrm{NA}$ \\
Poland & 0.57 & 0.49 \\
Portugal & 0.44 & 0.54 \\
Romania & $\mathrm{NA}$ & 0.34 \\
Sweden & 0.65 & 0.70 \\
Switzerland & 0.74 & $\mathrm{NA}$ \\
Slovenia & 0.46 & 0.56 \\
Slovakia & 0.66 & 0.66 \\
\hline
\end{tabular}

Note: "NA" means that the country was not used in the analysis due to missing data in (some or all) waves of the given survey. 
Table EA14: Descriptive statistics: EVS

\begin{tabular}{lccccc}
\hline Variable & $\mathrm{N}$ & Mean & SD & Min & Max \\
\hline Protest participation & 234347 & 0.270 & 0.440 & 0 & 1 \\
Left-wing & 234796 & 0.320 & 0.470 & 0 & 1 \\
Center & 234796 & 0.330 & 0.470 & 0 & 1 \\
L/R scale & 234796 & 5.090 & 2.170 & 0 & 10 \\
Reduce inequality & 232169 & 0.290 & 0.260 & 0 & 1 \\
Female & 234561 & 0.520 & 0.500 & 0 & 1 \\
Age & 233873 & 49.96 & 17.32 & 18 & 123 \\
Education (in years) & 232736 & 12.55 & 4.090 & 0 & 56 \\
Democratic satisfaction & 230586 & 5.320 & 2.440 & 0 & 10 \\
Very interested in politics & 234345 & 0.120 & 0.320 & 0 & 1 \\
Quite interested in politics & 234345 & 0.390 & 0.490 & 0 & 1 \\
Hardly interested in politics & 234345 & 0.350 & 0.480 & 0 & 1 \\
Not at all interested in politics & 234345 & 0.140 & 0.350 & 0 & 1 \\
TU member & 232108 & 0.210 & 0.410 & 0 & 1 \\
Ideological opponent of the incumbent cabinet & 234793 & 0.320 & 0.470 & 0 & 1 \\
\hline
\end{tabular}

Table EA15: Descriptive statistics: ESS

\begin{tabular}{lccccc}
\hline Variable & $\mathrm{N}$ & Mean & SD & Min & Max \\
\hline Protest participation & 102112 & 0.470 & 0.500 & 0 & 1 \\
Left-wing & 106869 & 0.460 & 0.500 & 0 & 1 \\
\hline
\end{tabular}




\section{Note on the Political Patterning in Hungary and Poland}

The political spaces of Poland and Hungary were in flux in the 1990s, but stabilized towards the end of the decade. We assess this development by considering party and voter placement on economic and cultural issues among the most significant parties of Hungary and Poland, using the Manifesto Project Data (Volkens et al., 2018), the Chapel Hill Expert Survey (CHES) data (Bakker et al., 2015, Polk et al., 2017), World and European Values Surveys, and the 1994 Hungarian Election Study (Klingemann and Toka, 1998).

Figures EA4 and EA5 show the over-time positional change of Hungarian and Polish parties. On economic issues, the dispersion of party placements decreases dramatically over the 1990s. This is particularly pronounced in Hungary, where by 2005 economic positions of major parties are hardly distinguishable. By the 2000s, the major right-wing competitors (Fidesz in Hungary, and PiS in Poland) are frequently to the left of the major left-wing parties (MSzP in Hungary, and SLD in Poland). 
Figure EA4: Hungarian party developments

\section{Hungary}

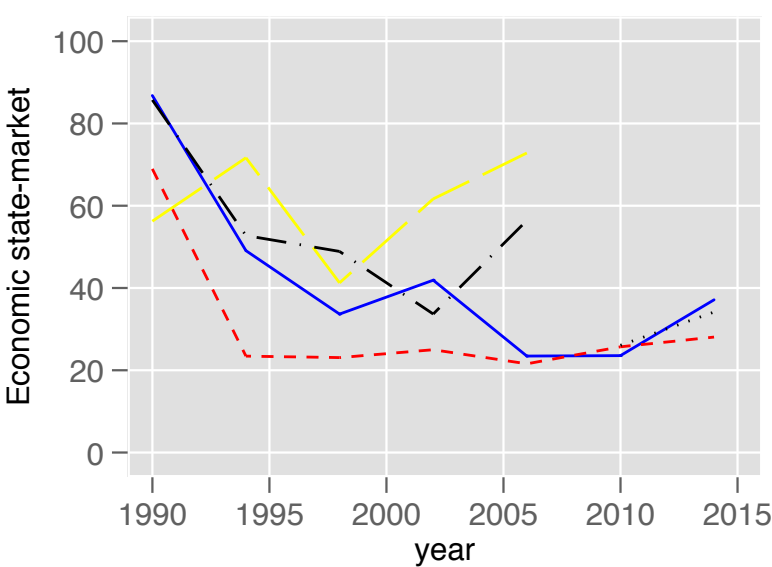

Manifestos

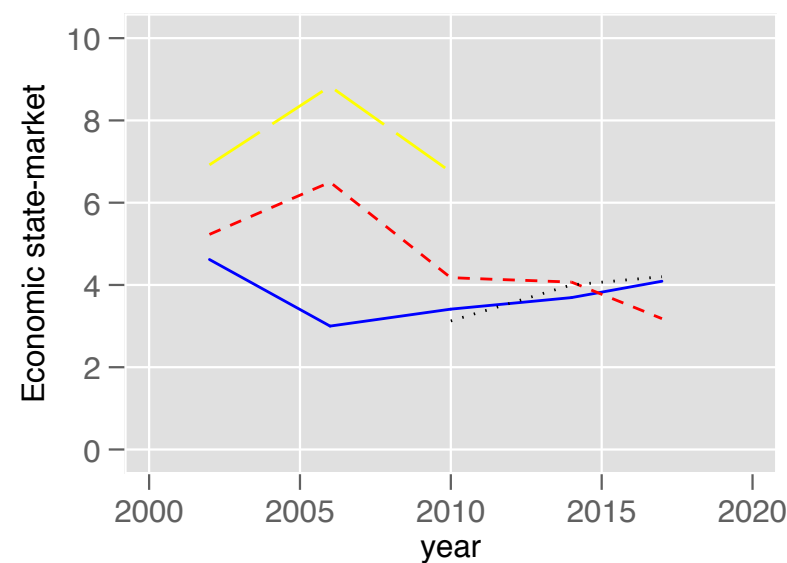

CHES

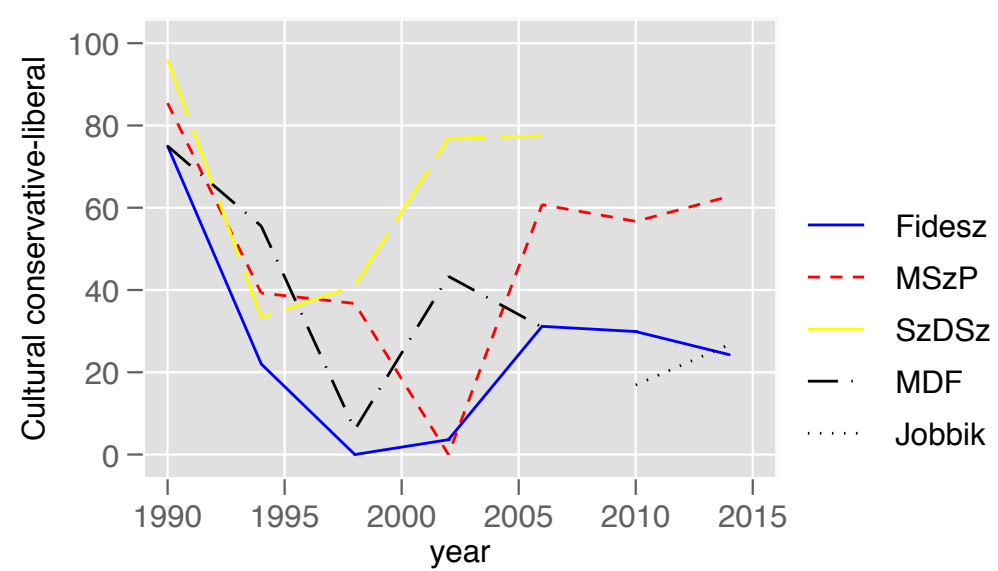

Manifestos

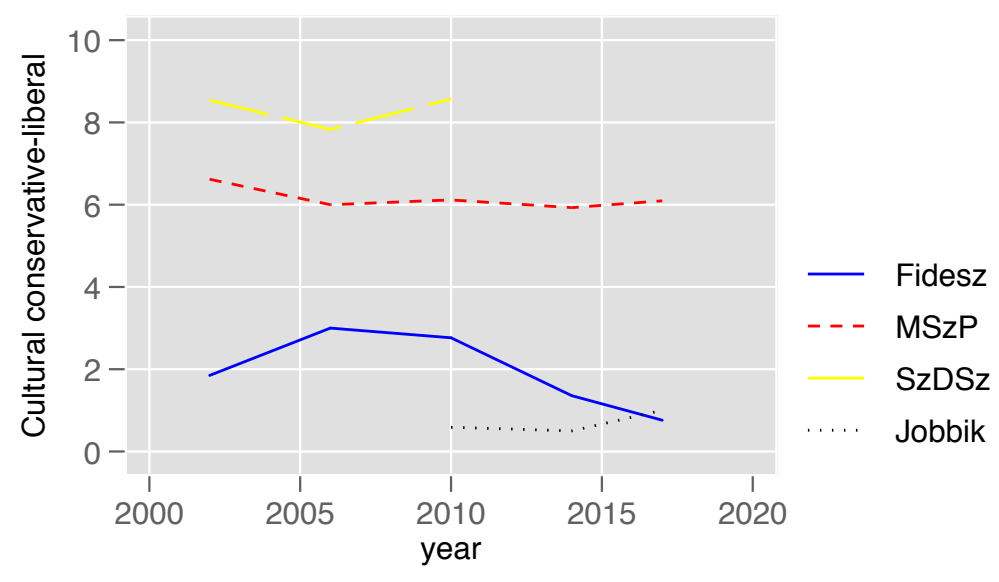

CHES 
Figure EA5: Polish party developments

\section{Poland}
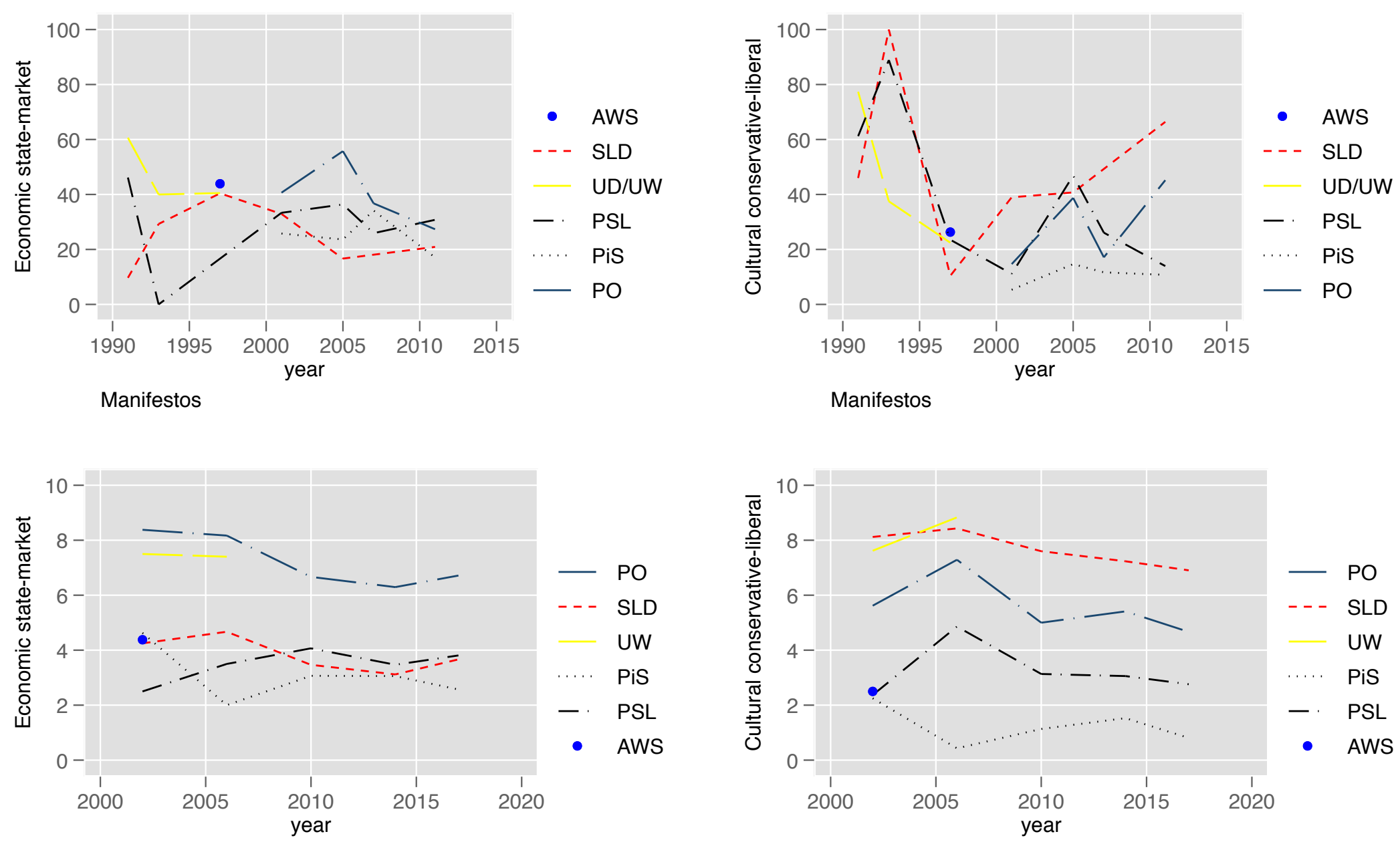

CHES 
On the cultural dimension, both countries manifest an initial spike in cultural liberalism (among almost all major parties) in the early 1990s, followed by a significant shift to cultural conservatism by the second half of the decade. This shift is, however, most significant and lasting on the part of the right-wing parties. By the 2000s, it is the left parties (MSzP and SLD) that dominate the culturally liberal pole, while the major rightwing competitors (Fidesz and PiS) dominate the culturally conservative end of the spectrum.

We can also see the formation of this space by examining the placement of parties and mean voters on the economic and cultural dimensions, depicted in figures EA4 and EA5. Here we see that in both countries the major left and liberal parties remain consistently placed. The ex-communist parties (MSzP and SLD) take statist and culturally moderately liberal positions, while liberal parties ( $\mathrm{SzDSz}$ and UD/UW) take up market economic and culturally liberal stances. 
Figure EA6: Hungarian political space

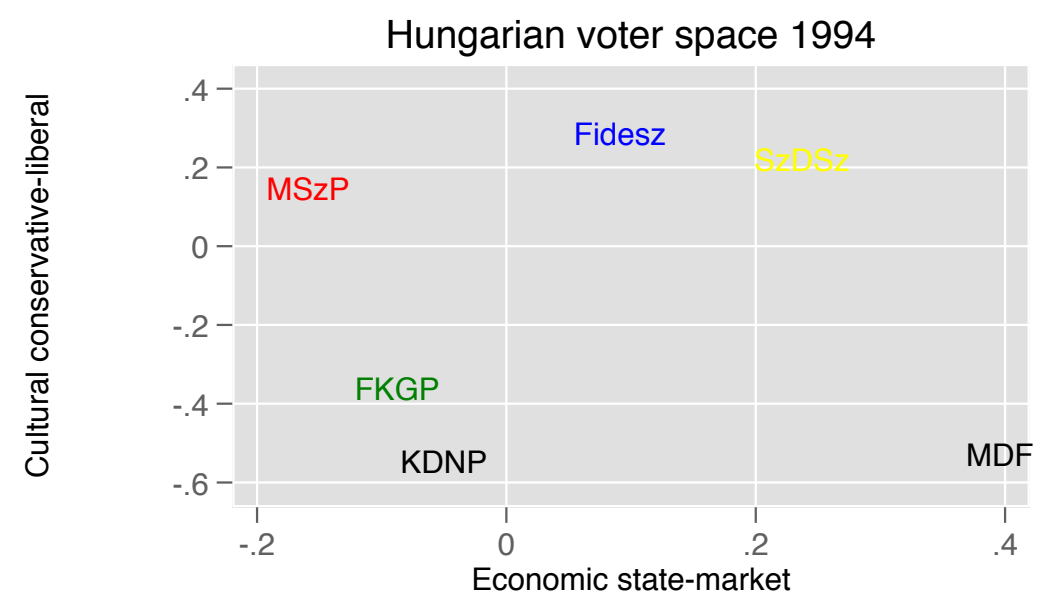

HU Election Study

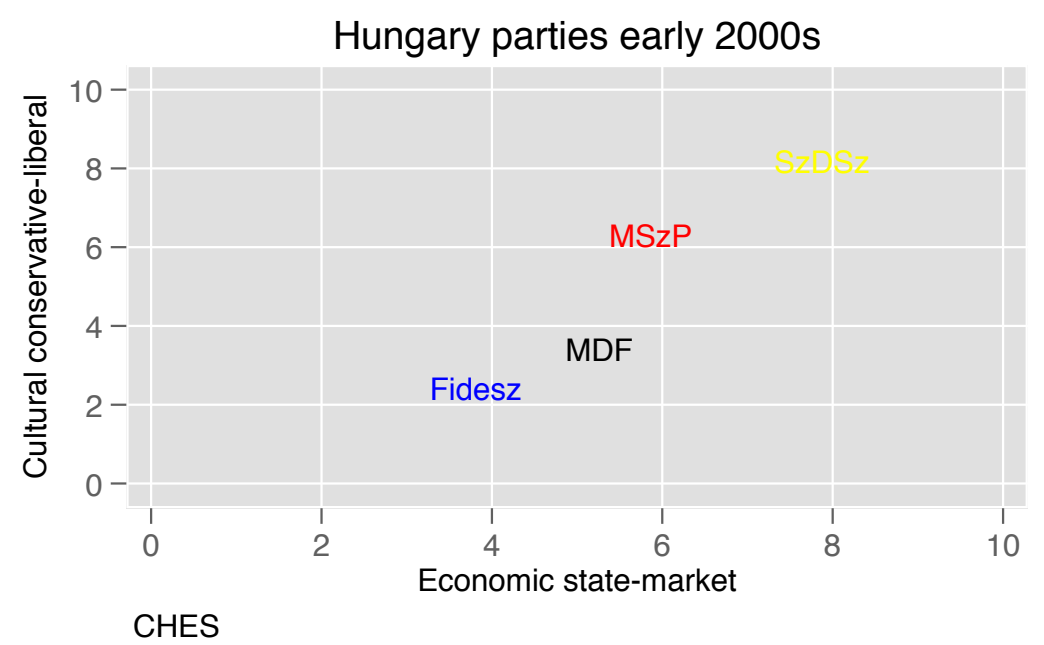

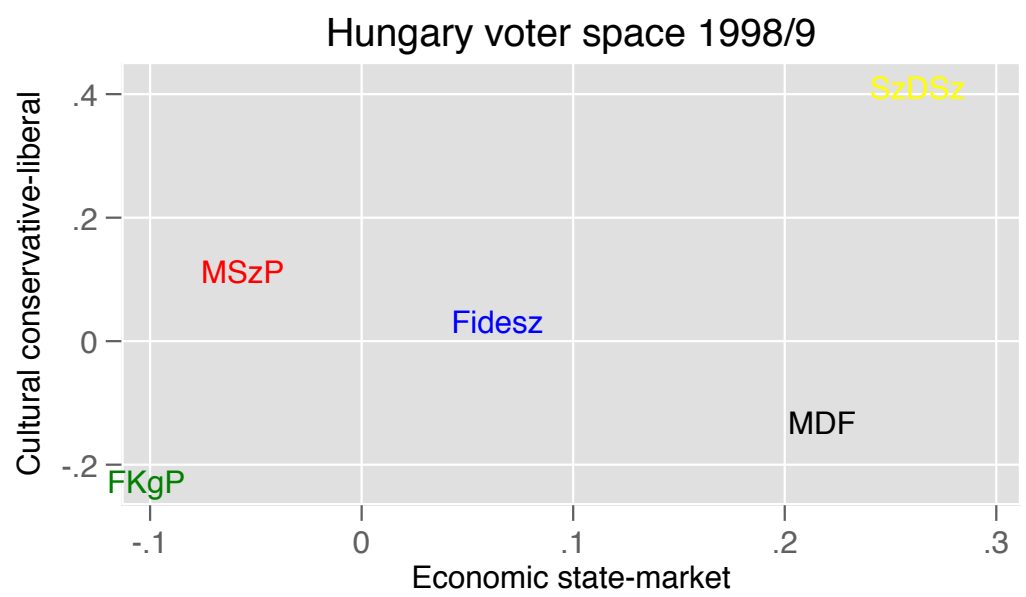

WVS, EVS

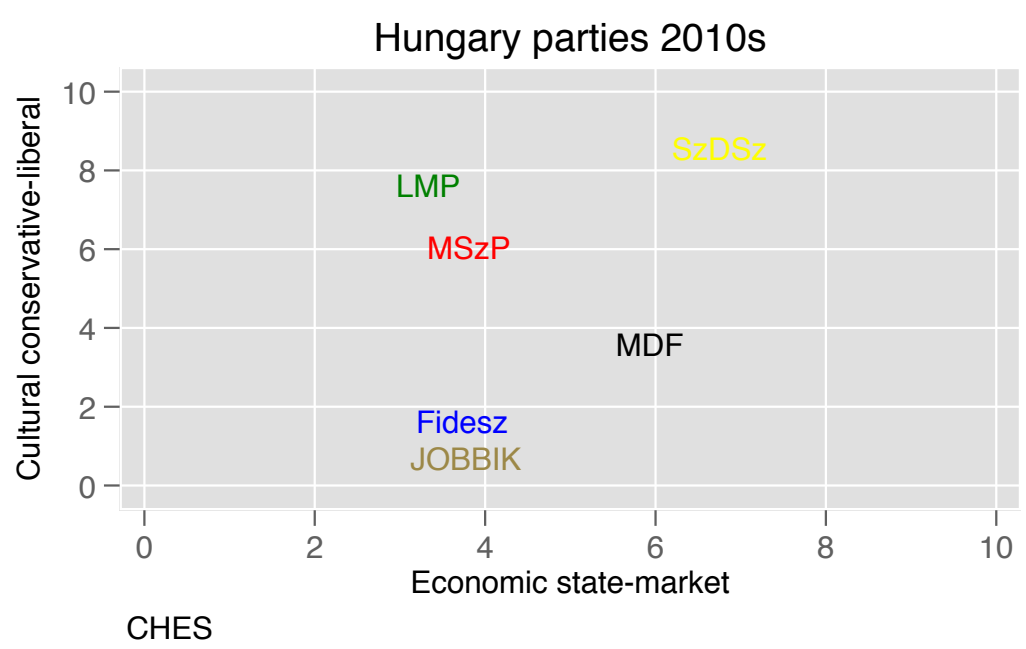


Figure EA7: Polish political space
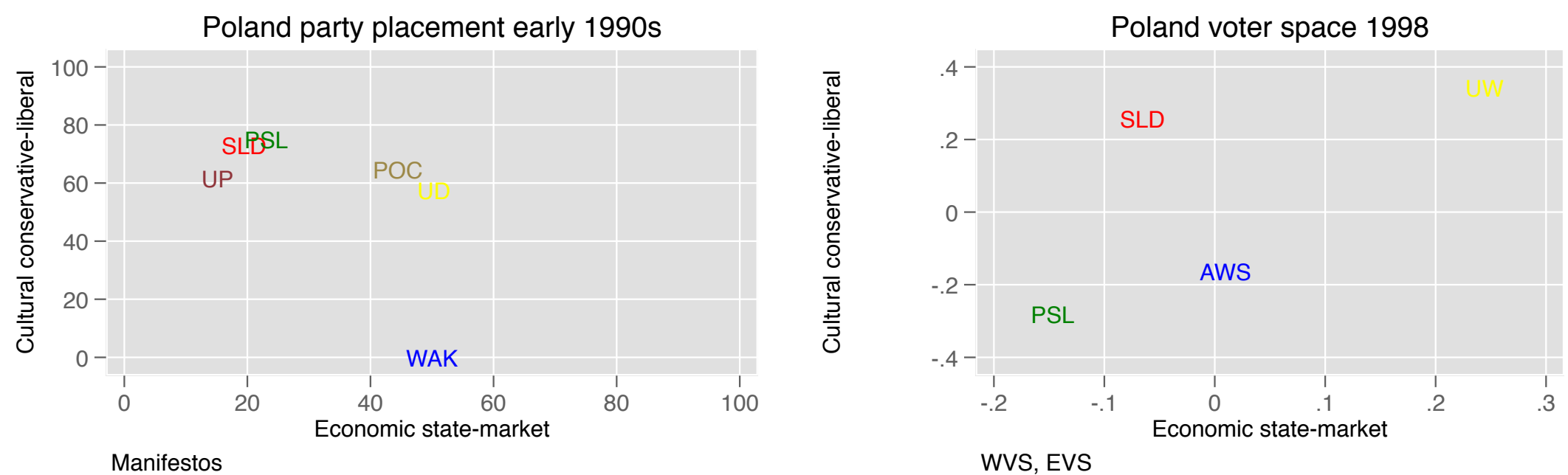

Poland parties early 2000 s

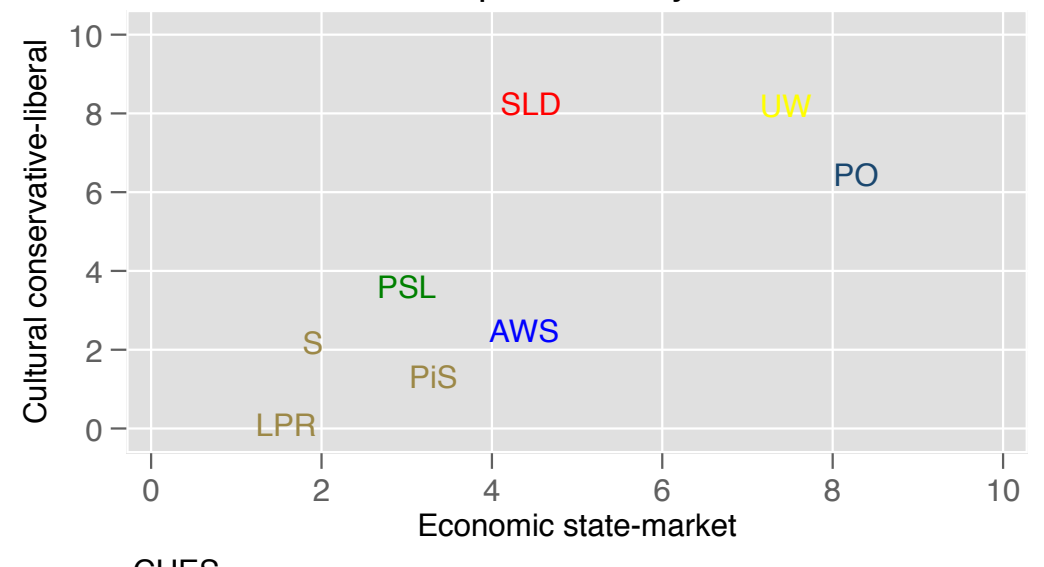

CHES

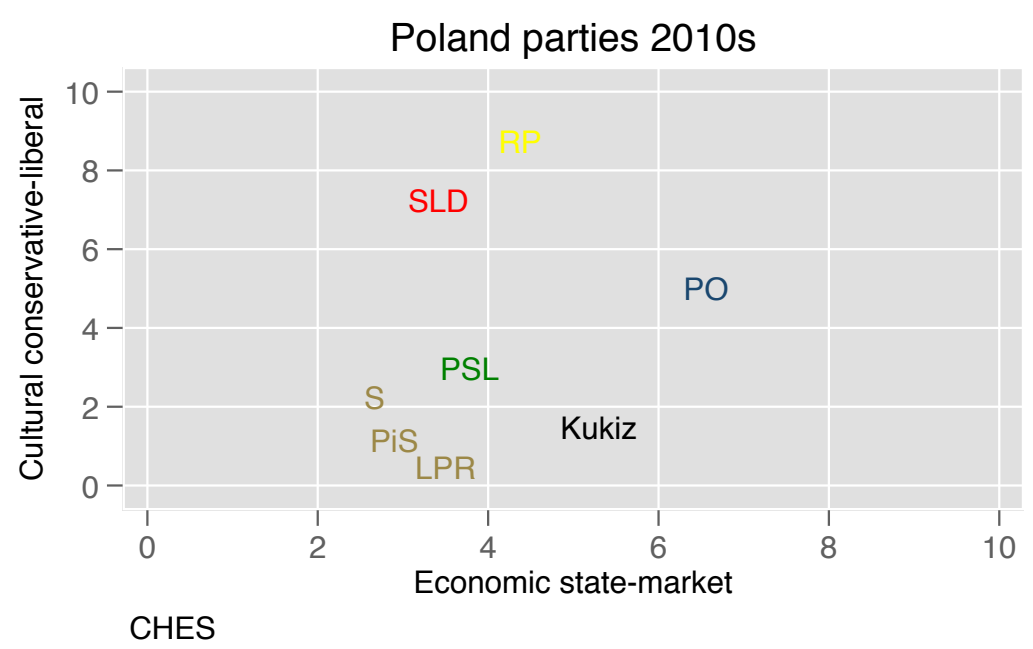


It is the major right parties whose positions are less fixed during the 1990s. In the early period, we see the Hungarian right dominated by the Christian Democratic and nationalist MDF, which throughout the 1990s seems to take distinctly pro-market economic positions, while being culturally conservative. Fidesz initially stands near, but to the statist side of the liberals, taking culturally liberal, but only moderate pro-market positions. This situation changes towards the late 1990s as MDF starts to lose its electoral primacy on the right to Fidesz. During this period Fidesz shifts significantly towards the culturally conservative end of the spectrum, while simultaneously shifting towards economic statism. While there is no clear competition patter that would connect the economic and cultural dimension in the early 1990s, the later 1990s see the formation of a connection between economic statism and cultural conservatism, positions driven by Fidesz and later also the radical right Jobbik.

In Poland the right is initially fragmented between the liberals (UD/UW), and various Christian factions. These Christians tend towards moderate cultural conservatism, but initially seem to be relatively pro-market oriented. As in Hungary, this changes in the late 1990s as the Electoral Action Solidarity (AWS) an umbrella grouping for the Christian right shifts towards the economic center, and eventually splinters. This splintering leads to the creation of a more liberal Civic Platform (PO), and a more Christian nationalist Law and Justice party (PiS). This fragmentation solidifies the patterning of Polish politics between economically statist cultural conservatives dominated by $\mathrm{PiS}$, and more culturally liberal economic centrists (SLD, RP) or free marketeers (PO).

In sum, while the Hungarian and Polish systems demonstrate initial tendencies towards cultural liberalism on the part of the right-wing parties, this liberalism is short-lived, and eclipsed by the (relative) liberalism of the major ex-communist left-wing competitors and liberals. Simultaneously, there is a relative shift of the major right-wing competitors to the economically statist positions, which are often more statist than (or hard 
to distinguish from) the positions of the socialist parties. By the late 1990s and early 2000s, this consequently produces a political space connecting statist economic positions (often associated with nominally 'right-wing' parties) with cultural conservatism, while pro-market stances are associated with cultural liberals. Hungary and Poland thus ultimately follow the eastern pattern. 